\title{
Trends and Causes of Historical Wetland Loss, Sabine National Wildlife Refuge, Southwest Louisiana
}

By Julie C. Bernier, Robert A. Morton, and Kyle W. Kelso
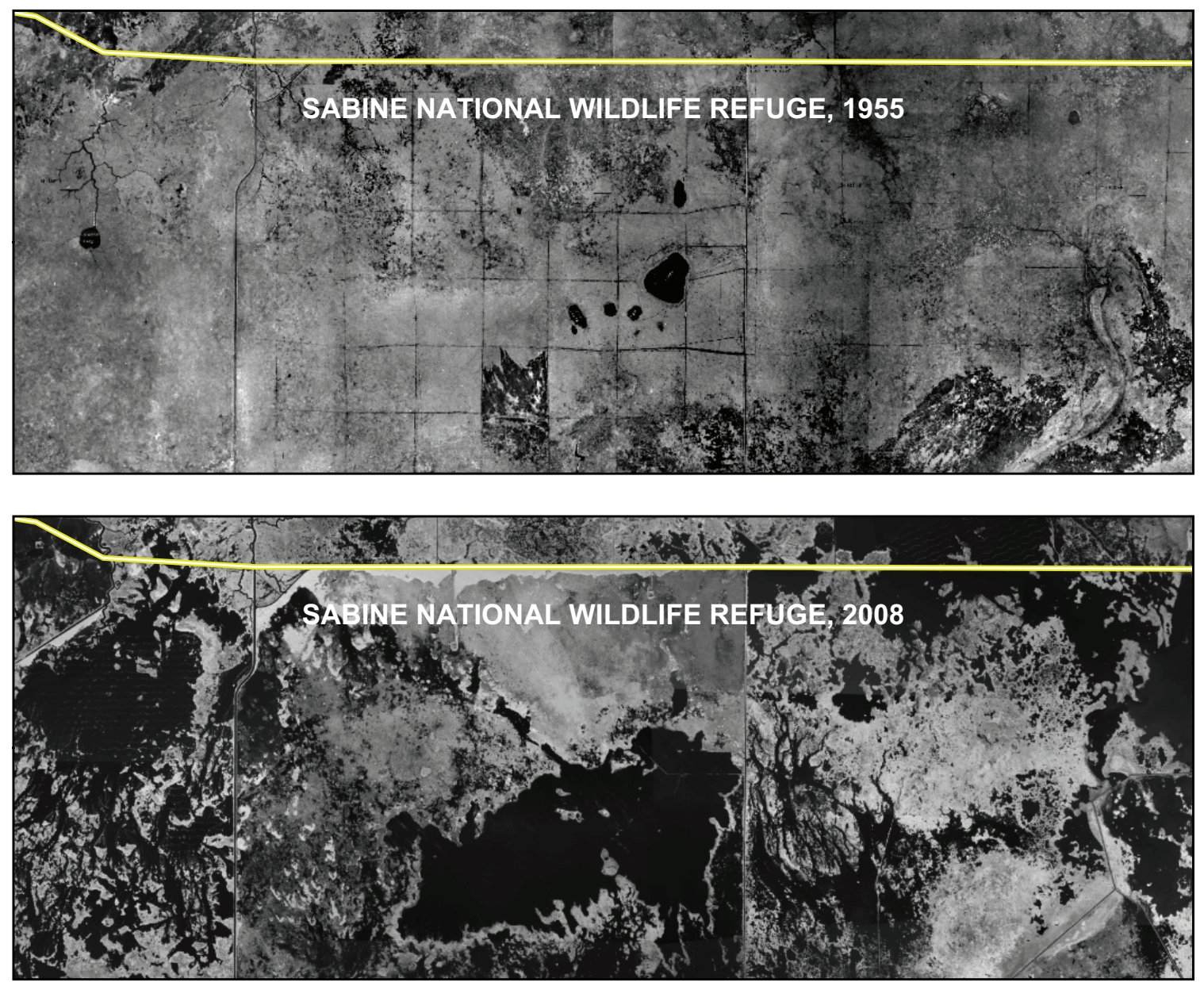

Open File Report 2011-1169

U.S. Department of the Interior

U.S. Geological Survey 
Cover: Aerial photographs from 1955 and 2008 illustrate the extent of wetland loss in Sabine National Wildlife Refuge in the western chenier plain, Cameron Parish, Louisiana. Scale 1:150,000. 


\section{Trends and Causes of Historical Wetland Loss, Sabine National Wildlife Refuge, Southwest Louisiana}

By Julie C. Bernier, Robert A. Morton, and Kyle W. Kelso

Open File Report 2011-1169

U.S. Department of the Interior

U.S. Geological Survey 


\title{
U.S. Department of the Interior KEN SALAZAR, Secretary
}

\author{
U.S. Geological Survey \\ Marcia K. McNutt, Director
}

U.S. Geological Survey, Reston, Virginia: 2011

For product and ordering information:

World Wide Web: http://www.usgs.gov/pubprod

Telephone: 1-888-ASK-USGS

For more information on the USGS - the Federal source for science about the Earth, its natural and living resources, natural hazards, and the environment:

World Wide Web: http://www.usgs.gov

Telephone: 1-888-ASK-USGS

Any use of trade, product, or firm names is for descriptive purposes only and does not imply endorsement by the U.S. Government.

Although this report is in the public domain, permission must be secured from the individual copyright owners to reproduce any copyrighted materials contained within this report.

Suggested citation:

Bernier, J.C., Morton, R.A., Kelso, K.W., 2011, Trends and Causes of Historical Wetland Loss, Sabine National Wildlife Refuge, Southwest Louisiana, U.S. Geological Survey, Open File Report 2011-1169, 36p., plus app. 


\section{Contents}

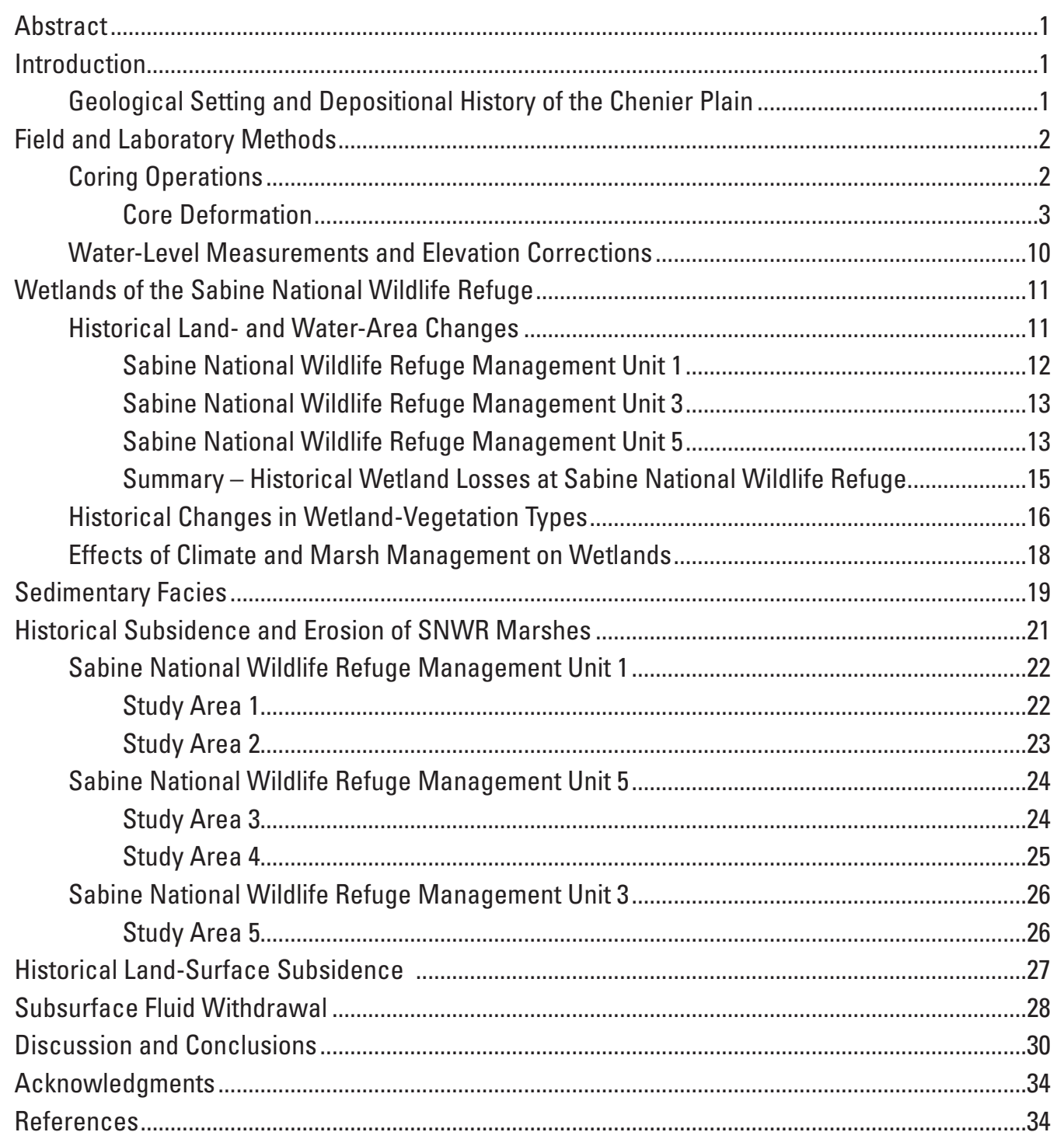




\section{Figures}

Figure 1. Regional map of the Calcasieu-Sabine hydrologic basin in southwestern Louisiana showing locations of coring sites in Sabine National Wildlife Refuge (SNWR) relative to SNWR management units and nearby hydrologic gages

Figure 2. Regional map of the Calcasieu-Sabine hydrologic basin in southwestern Louisiana showing locations of coring sites, oil-and-gas fields, Pleistocene sediments, and areas of historical wetland loss from 1932 to 2006 .

Figure 3. Water levels recorded at (A) Coastwide Reference Monitoring System (CRMS) site \#0641 on June 4-8, 2008, (B) Louisiana Office of Coastal Protection and Restoration (OCPR) coastal monitoring station \#CS02-05 on June 4-8, 2008, (C) CRMS site \#0660 on June 7-12, 2008, and (D) CRMS site \#0694 on August 5-10, 2010.

Figure 4. Map of Sabine National Wildlife Refuge (SNWR) Management Unit 1 showing locations of coring sites and historical land-loss trends between 1932 and 2006

Figure 5. Locations of sediment cores at Sabine National Wildlife Refuge (SNWR) Management Unit 1 superimposed on pre- and post-land-loss aerial photographs taken in (A) 1955,

(B) 1965, (C) 1978, and (D) 2008

Figure 6. Map of Sabine National Wildlife Refuge (SNWR) Management Unit 3 showing locations of coring sites and historical land-loss trends between 1932 and 2006.

Figure 7. Locations of sediment cores at Sabine National Wildlife Refuge (SNWR) Management Unit 3 superimposed on pre- and post-land-loss aerial photographs taken in (A) 1955, (B) 1965, (C) 1978, and (D) 2008

Figure 8. Map of Sabine National Wildlife Refuge (SNWR) Management Unit 5 showing locations of coring sites, Pleistocene sediments, and historical land-loss trends between 1932 and 2006

Figure 9. Locations of sediment cores and Pleistocene sediments at Sabine National Wildlife Refuge (SNWR) Management Unit 5 superimposed on pre- and post-land-loss aerial photographs taken in (A) 1955, (B) 1965, (C) 1978, and (D) 2008.

Figure 10. Linear-regression trend for mean annual water levels at Calcasieu Pass recorded at the U.S. Army Corps of Engineers Cameron tide gage (USACE \#73650) from 1942 to 2005 .

Figure 11. Conceptual diagram showing the geometric derivation of the reference stratigraphic section used to estimate the subsidence and erosion components contributing to the total one-dimensional accommodation space at an open-water core site.

Figure 12. Locations of sediment cores and sediment-surface profiles collected at Sabine National Wildlife Refuge study area 1.

Figure 13. Combined bathymetric profile and stratigraphic cross section for marsh and openwater core sites SB1-09 to SB1-01 illustrating the magnitude of subsidence and wetland erosion at study area 1

Figure 14. Locations of sediment cores and sediment-surface profiles collected at Sabine National Wildlife Refuge study area 2.

Figure 15. Combined bathymetric profile and stratigraphic cross section for marsh and openwater core sites SB1-18 to SB1-20 illustrating the magnitude of subsidence and wetland erosion (in centimeters) at study area 2 .

Figure 16. Combined bathymetric profile and stratigraphic cross section for marsh and open-water 


\section{Figures continued}

core sites SB1-13 to SB1-16 illustrating the magnitude of subsidence and wetland erosion

(in centimeters) at study area 2 ..................................................................................2

Figure 17. Locations of sediment cores and sediment-surface profiles collected at Sabine

National Wildlife Refuge study area 3.

Figure 18. Combined bathymetric profile and stratigraphic cross section for marsh and openwater core sites SB5-08 to SB5-012 illustrating the magnitude of subsidence and wetland erosion at study area 3 .

Figure 19. Combined bathymetric profile and stratigraphic cross section for marsh and openwater core sites SB5-01 to SB5-07 illustrating the magnitude of subsidence and wetland erosion at study area 3 .

Figure 20. Locations of sediment cores and sediment-surface profiles collected at Sabine National Wildlife Refuge study area 4.

Figure 21. Combined bathymetric profile and stratigraphic cross section for marsh and openwater core sites SB5-24 to SB5-36 illustrating the magnitude of subsidence and wetland erosion at study area 4.

Figure 22. Combined bathymetric profile and stratigraphic cross section for (A) marsh and openwater core sites SB5-32 to SB5-30 and (B) core sites SB5-35 to SB5-40 illustrating the magnitude of subsidence and wetland erosion at study area 4.

Figure 23. Locations of sediment cores and sediment-surface profiles collected at Sabine National Wildlife Refuge study area 5.

Figure 24. Combined bathymetric profile and stratigraphic cross section for marsh and openwater core sites SB3-01 to SB3-06 illustrating the magnitude of subsidence and wetland erosion at study area 5 .

Figure 25. Annual fluid production through 2009 from oil-and-gas fields surrounding the Sabine National Wildlife Refuge. (A) Black Bayou complex, (B) East and West Hackberry complex, (C) Cameron Meadows complex, and (D) Mud Lake and Second Bayou complex 


\section{Tables}

Table 1. Adjusted depths (thickness) and NAVD88 elevations for stratigraphic contacts correlated between cores at Sabine National Wildlife Refuge.

Table 2. Types and sources of imagery used to investigate land-water changes in the Sabine National Wildlife Refuge and surrounding areas.

Table 3. Discovery year, number of wells drilled, and cumulative volumes of fluids produced through 2009 from oil-and-gas field complexes surrounding the Sabine National Wildlife Refuge wetlands.

Table 4. Comparison and ranges of parameters at wetland-loss sites in the chenier and delta plains. 


\section{Conversion Factors}

\begin{tabular}{llll}
\hline \multicolumn{1}{c}{ Multiply } & \multicolumn{1}{c}{ By } & To obtain \\
\hline \multicolumn{1}{c}{ Length } \\
\hline centimeter $(\mathrm{cm})$ & 0.3937 & inch (in.) \\
meter $(\mathrm{m})$ & 3.281 & foot (ft) & mile (mi) \\
kilometer $(\mathrm{km})$ & 0.6214 & \\
\hline \multicolumn{2}{c}{ Area } & \\
\hline square kilometer $\left(\mathrm{km}^{2}\right)$ & 247.1 & acre \\
\hline
\end{tabular}

Vertical coordinate informaton is referenced to the North American Vertical Datum of 1988 (NAVD 88).

Horizontal coordinate informaton is referenced to the North American Datum of 1983 (NAD 83). 



\title{
Trends and Causes of Historical Wetland Loss, Sabine National Wildilife Refuge, Southwest Louisiana
}

\author{
By Julie C. Bernier, Robert A. Morton, and Kyle W. Kelso
}

\section{Abstract}

Prior U.S. Geological Survey studies (Open-File Reports 2005-1216 and 2009-1158) examined historical land- and water-area changes and estimated magnitudes of land subsidence and erosion at 10 wetland sites in the Mississippi River delta plain. The present study extends that work by analyzing interior wetland loss and relative magnitudes of subsidence and erosion at five additional wetland sites in Sabine National Wildlife Refuge (SNWR) in the western chenier plain. The study sites were selected because their geologic setting differed from that of the delta plain; also, although the refuge marshes had been managed partly to minimize wetland loss, interior wetland losses there were extensive. Historical aerial photography, datum-corrected marsh elevations and water depths, and sediment cores were integrated to evaluate historical land- and water-area changes at SNWR.

The thickness of the uppermost Holocene sediments (peat and organic-rich mud) and the elevation of stratigraphic contacts were compared at marsh and open-water sites across areas of formerly continuous marsh to estimate magnitudes of recent elevation loss caused by vertical erosion and subsidence. Results of these analyses indicate that erosion greatly exceeded subsidence at most of the core sites, although both processes have contributed to historical wetland loss. Comparison of these results with results of our prior studies indicates that magnitudes of subsidence and total accommodation space that formed in the western chenier plain were less than those in the delta plain. Compared with the delta plain, where subsidence generally exceeded erosion and peat thicknesses were so great that peat was preserved even where erosion was greater than subsidence, the SNWR peats are thin and were absent (eroded) at most open-water sites. Although historical subsidence rates in the chenier plain are substantially lower than most of the same rates in the delta plain, the temporal and spatial trends of rapid wetland loss, highest rates of land-surface subsidence, and high rates of oil-and-gas production are similar, indicating that historical wetland loss was likely initiated by similar processes (deepsubsurface subsidence) in both regions.

\section{Introduction}

Wetland loss in coastal Louisiana has been such an important environmental and economic issue that decades of scientific research have been dedicated to the topic since the trend was first recognized in the late 1960s (National Research Council, 2006). In support of that effort, the U.S. Geological Survey (USGS) has been conducting research directed toward a better understanding of the physical processes and human activities that contribute to wetland loss and the timing of that loss. Recent USGS efforts have concentrated on hotspot areas of the Mississippi delta plain, where high rates of interior wetland loss were difficult to explain when only surficial processes and wetland ecology were considered. Prior USGS studies that examined interior wetland loss in the delta region demonstrated close temporal and spatial correlations between wetland loss, delta-plain subsidence, and deep-subsurface hydrocarbon production (Morton and others, 2003; 2005; 2006; 2009a; Morton and Bernier, 2010).

To complement the extensive wetland-loss research conducted in the delta plain, fieldwork completed in 2008 and 2010 was designed to investigate the temporal and spatial distribution of wetland loss in the western chenier plain, which has a different geological setting and depositional style than the delta plain, using the same techniques and general data sources that were used in the delta plain. The Sabine National Wildlife Refuge (SNWR) in the Calcasieu-Sabine hydrologic basin (figs. 1 and 2) was selected for study because interior wetland loss there had been extensive, the refuge marshes had been managed partly to minimize wetland loss, and study sites were accessible by airboat without concern for land-ownership issues.

\section{Geological Setting and Depositional History of the Chenier Plain}

The modern Mississippi River and delta overlie a deep incised valley that was excavated during the last Pleistocene fall and lowstand in sea level. The valley was subsequently backfilled when sea level rose during the late Pleistocene and Holocene (Kolb and Van Lopik, 1958). Within the valley fill, the Holocene sedimentary section is more than 60 meters (m) thick (Roberts, 1997). The extant delta plain was constructed by sediment transported through a series of distributary channels that deposited overlapping delta lobes (Frazier, 1967). In general, the direction of sediment supply was perpendicular or at a high angle to the gulf shoreline. This depositional style left remnant active and abandoned distributary channels and promoted the development of lakes (areas of incomplete filling) and a network of tidal channels in the wetlands. 


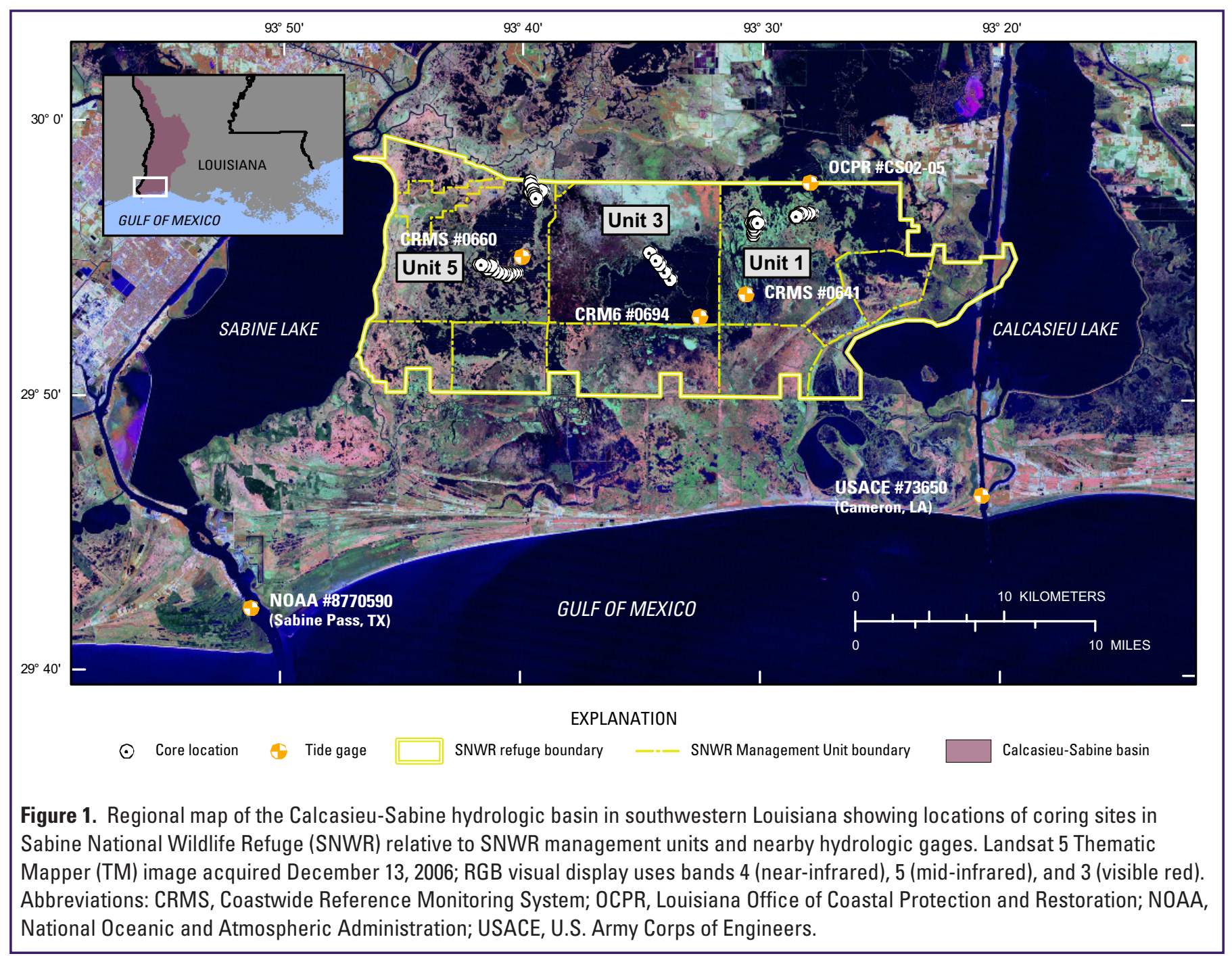

In contrast to the geologic setting of the delta plain, the chenier plain consists of a thin wedge of Holocene sediments overlying stiff over-compacted Pleistocene sediments that were subaerially exposed during the late Pleistocene sea-level lowstand. Sabine and Calcasieu Lakes are unfilled remnants of incised valleys excavated by the Sabine-Neches and Calcasieu Rivers, respectively, during the same lowstand. Cores taken by Gould and McFarlan (1959) show that below the chenier-plain surface, muddy sediments above the Pleistocene-Holocene unconformity range in thickness from less than a meter to about $6 \mathrm{~m}$, with thickness generally increasing toward the Gulf of Mexico.

The chenier plain was constructed by progradation of the gulf shoreline as the coastal plain advanced seaward with the addition of broad mudflats and intervening narrow, sandy beach ridges (cheniers). Radiocarbon dates from the beach ridges indicate that progradation of the chenier plain began about 3,000 years ago (Gould and McFarlan, 1959; Penland and Suter, 1989; McBride and others, 2007). In general, the direction of sediment supply for the chenier plain was parallel to the gulf shoreline because sediment transport by coastal- plain rivers is trapped in Sabine and Calcasieu Lakes. As a result of the alongshore processes of sediment progradation and aggradation, only a few tidal channels were constructed within the chenier-plain wetlands, and vast continuous meadows of dense wetland grasses were the natural setting before they were altered by human activities.

\section{Field and Laboratory Methods}

\section{Coring Operations}

Both push cores and vibracores were used to determine the thickness and characteristics of shallow sediments beneath the chenier plain at SNWR using the methods described in Morton and others (2009a; 2009b). The push cores and vibracores are designated 'p' and 'v,' respectively, after the core number (table 1; appendix A). The 'p' and ' $\mathrm{v}$ ' designations are not used when referring to a specific core site rather than to individual cores. A Russian peat corer (Jowsey, 1966) was 


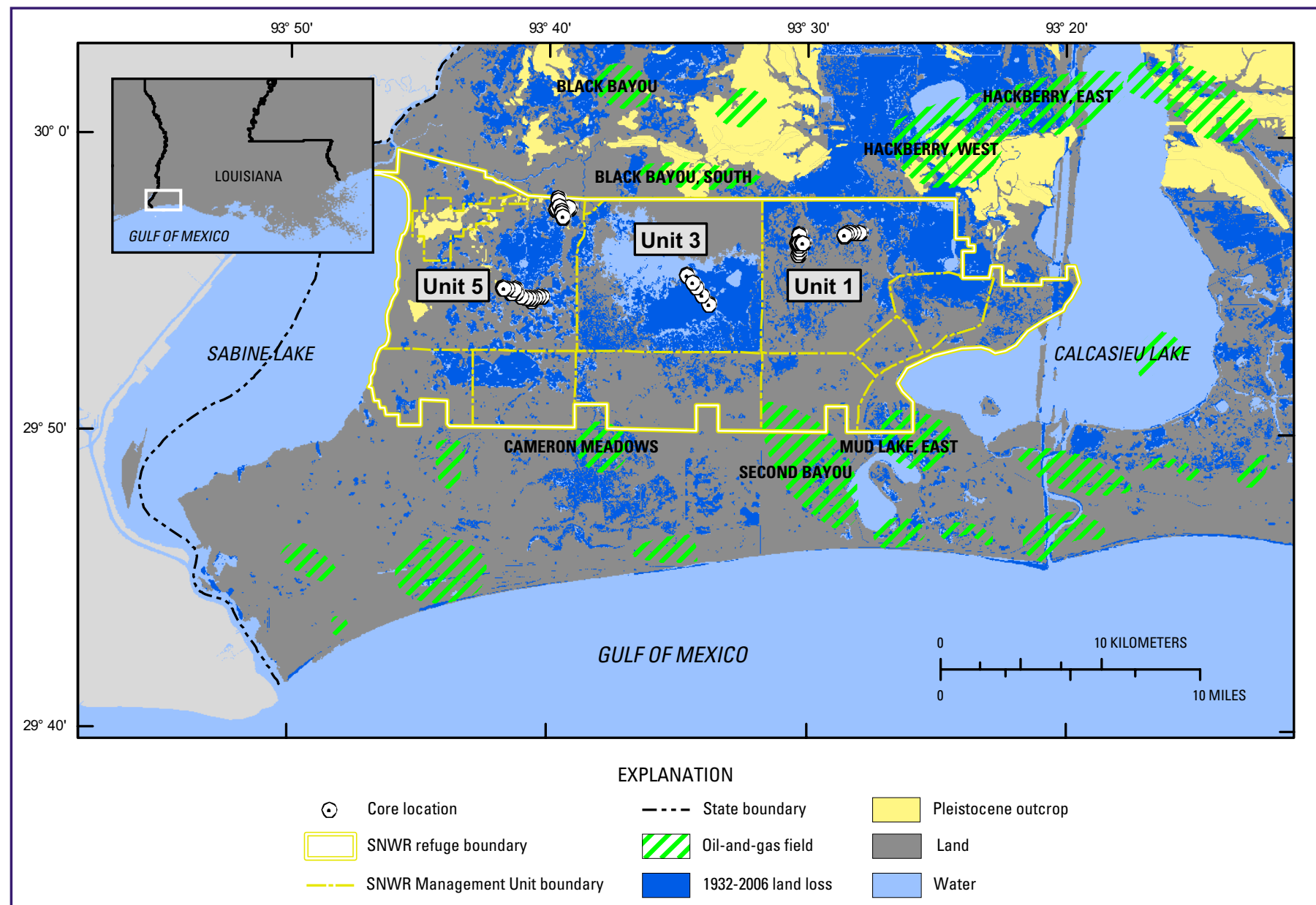

Figure 2. Regional map of the Calcasieu-Sabine hydrologic basin in southwestern Louisiana showing locations of coring sites, oil-andgas fields, Pleistocene sediments (Heinrich and others, 2002; Henirich, 2005a), and areas of historical wetland loss from 1932 to 2006.

used to collect sediment cores in 50-centimeter $(\mathrm{cm})$ intervals at each of the emergent-marsh, marsh-edge, and open-water coring sites. If the organic-clastic contact was not recovered in the first 50-cm coring interval, the push corer was inserted into the same hole left by extraction of the previous core in order to limit resistance against the coring device and to ensure recovery of the correct depth interval. Each $50-\mathrm{cm}$ core section was transferred into pre-cut, semi-cylindrical PVC pipe. The cores were then encased in plastic wrap, sealed to retain moisture, and labeled according to core number, core interval, and orientation.

Vibracores were collected only at the emergent-marsh sites in SNWR Management Units 1 and 5. The vibracoring technique was illustrated and described by Lanesky and others (1979). Compared to push cores, vibracores provide deeper, continuous penetration, which can reveal stratigraphy below the organic-rich sediments that occur near the surface. After extraction, each continuous core length was capped, sealed, and labeled with the core number and orientation.

Twenty-three vibracores and 95 push cores were located with a portable Global Positioning System (GPS) receiver at the five study sites. Cores taken along transects across areas of historic wetland loss provided close stratigraphic correlation between the present emergent-marsh sediments and adjacent open-water sediments, where emergent marsh formerly existed.

The cores were transported to the USGS St. Petersburg Coastal and Marine Science Center in Florida. Each vibracore was cut into 1-m sections and split lengthwise. The push cores and one-half of each vibracore were cleaned, photographed, and described in detail. The second half of each split vibracore was immediately sealed for future sampling. All core sections were then placed in containers and stored onsite. The core descriptions and photographs (appendix A) were used to identify the predominant sedimentary facies and to select stratigraphic contacts that were correlated between cores and used to estimate magnitudes of wetland subsidence and erosion (table 1).

\section{Core Deformation}

The peat sections recovered in the push cores typically are thicker than those recovered by the vibracores at the same 
Table 1. Adjusted depths (thickness) and NAVD88 elevations for stratigraphic contacts correlated between cores at Sabine National Wildlife Refuge.

[A detailed derivation of the reference stratigraphic section for each study area is given in appendix B. The specific reference stratigraphic thicknesses and contact elevations at each core site are a function of the adjacent emergent-marsh stratigraphy and distance along the transect. Positive marsh-minuswater (m-w) adjusted depth-difference values indicate erosion, and negative $\mathrm{m}$-w depth-difference values indicate sediment accumulation; m-w adjusted elevation-difference values represent estimated subsidence. Cores are arranged in the same order that they are shown on the stratigraphic cross sections (figs. 13, 15, 16, 18, 19, 21, 22, and 24). cm, centimeters]

\begin{tabular}{|c|c|c|c|c|c|c|}
\hline \multirow[b]{2}{*}{ Core ID } & \multirow[b]{2}{*}{ Core location } & \multirow[b]{2}{*}{$\begin{array}{l}\text { Core } \\
\text { elevation } \\
\text { (cm) }\end{array}$} & \multicolumn{2}{|c|}{ Base unit 1} & \multicolumn{2}{|c|}{ Base unit 2} \\
\hline & & & $\begin{array}{l}\text { Contact } \\
\text { depth } \\
\text { (cm) }\end{array}$ & $\begin{array}{l}\text { Contact } \\
\text { elevation } \\
\text { (cm) }\end{array}$ & $\begin{array}{l}\text { Contact } \\
\text { depth } \\
\text { (cm) }\end{array}$ & $\begin{array}{l}\text { Contact } \\
\text { elevation } \\
\text { (cm) }\end{array}$ \\
\hline
\end{tabular}

reference section at SB1-10
SB1-10p
difference (m-w)
reference section at SB1-27
SB1-27p
difference (m-w)
reference section at SB1-26
SB1-26p
difference (m-w)
reference section at SB1-08
SB1-08p

difference $(\mathrm{m}-\mathrm{w})$

reference section at SB1-25

SB1-25p

difference $(\mathrm{m}-\mathrm{w})$

reference section at SB1-06

SB1-06p

difference $(\mathrm{m}-\mathrm{w})$

reference section at SB1-24

SB1-24p

difference (m-w)

reference section at SB1-04

SB1-04 $p^{1}$

difference $(\mathrm{m}-\mathrm{w})$

reference section at SB1-23

SB1-23p

difference $(\mathrm{m}-\mathrm{w})$

reference section at SB1-22

SB1-22 $p^{1}$

difference $(\mathrm{m}-\mathrm{w})$
Study area 1: transect SB1-09 to SB1-01 (fig. 13)

$\begin{array}{llllll}\text { marsh } & 50 & 17 & 33 & 31 & 19 \\ \text { marsh edge } & \underline{13} & \underline{10} & \underline{3} & \underline{20} & \frac{-7}{26}\end{array}$

marsh 46

water $\underline{4}$

42

$\begin{array}{ll}31 & 15 \\ \underline{12} & \underline{-8} \\ 19 & 23\end{array}$

marsh

31

$\underline{14}$

17

water

$\underline{3}$

36

15

$\underline{-8}$

marsh

marsh edge

31

$\underline{18}$

13

marsh

32

water

marsh

33

marsh edge

17

16

marsh

36

3

33

marsh

45

marsh edge

8

37

marsh

42

water

marsh

water

$\underline{2}$

23
12

31

$\underline{22}$

9

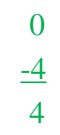

$-1$

$\underline{-5}$

$\frac{10}{23} \quad \frac{-5}{4}$

$\begin{array}{ll}35 & -2 \\ 17 & \underline{0} \\ 18 & -2\end{array}$

$\begin{array}{ll}37 & -1 \\ \frac{10}{27} & \frac{-7}{6}\end{array}$

$43 \quad 2$

$14 \quad \underline{-6}$

$29 \quad 8$

$42 \quad 0$

$\underline{10} \quad \underline{-10}$

$32 \quad 10$

$40 \quad-1$

$\underline{17} \quad \underline{-15}$

37

$23 \quad 14$ 
Table 1 continued. Adjusted depths (thickness) and NAVD88 elevations for stratigraphic contacts correlated between cores at Sabine National Wildlife Refuge.

\begin{tabular}{|c|c|c|c|c|c|c|}
\hline \multirow[b]{2}{*}{ Core ID } & \multirow[b]{2}{*}{ Core location } & \multirow[b]{2}{*}{$\begin{array}{l}\text { Core } \\
\text { elevation } \\
\text { (cm) }\end{array}$} & \multicolumn{2}{|c|}{ Base unit 1} & \multicolumn{2}{|c|}{ Base unit 2} \\
\hline & & & $\begin{array}{c}\text { Contact } \\
\text { depth } \\
\text { (cm) }\end{array}$ & $\begin{array}{l}\text { Contact } \\
\text { elevation } \\
\text { (cm) }\end{array}$ & $\begin{array}{l}\text { Contact } \\
\text { depth } \\
\text { (cm) }\end{array}$ & $\begin{array}{l}\text { Contact } \\
\text { elevation } \\
\text { (cm) }\end{array}$ \\
\hline
\end{tabular}

reference section at SB1-02

SB1-02p

difference $(\mathrm{m}-\mathrm{w})$

reference section at SB1-19

SB1-19p

difference $(\mathrm{m}-\mathrm{w})$

reference section at SB1-34

SB1-34p

difference (m-w)

reference section at SB1-35

SB1-35p ${ }^{2}$

difference $(\mathrm{m}-\mathrm{w})$

reference section at SB1-37

SB1-37p

difference (m-w)

reference section at $\mathrm{SB} 1-21$

SB1-21p

difference (m-w)

SB1-13p

SB1-11p

difference

reference section at SB1-12

SB1-12p

difference (m-w)

reference section at SB1-28

SB1-28p

difference (m-w)

reference section at SB1-29

SB1-29p

difference $(\mathrm{m}-\mathrm{w})$

$\begin{array}{llllll}\text { marsh } & 36 & 26 & 10 & 39 & -3 \\ \text { marsh edge } & \frac{14}{22} & \frac{17}{9} & \frac{-3}{13} & \underline{28} & \frac{-14}{11}\end{array}$

Study area 2: transect SB1-18 to SB1-20 (fig. 15)

marsh

48

32

16

40

marsh edge

$\underline{14}$

$\underline{20}$

$\underline{-6}$

12

marsh

47

37

10

water

$-3$

50

$-17$

$\underline{14} \quad \underline{-17}$

marsh

47

23

27

water

$-6$

53

\begin{tabular}{lr}
35 & 12 \\
$\frac{19}{16}$ & $\underline{-23}$ \\
\hline 5
\end{tabular}

marsh

46

$\underline{2}$

29

17

water

44

$-9$

marsh 46

$\begin{array}{llll}46 & 20 & 26 & 25\end{array}$

(1)

marsh edge

$\underline{16}$

30

$\frac{7}{13}$

9

17

$\underline{11}$

2

$\frac{5}{16}$

Study area 2: transect SB1-13 to SB1-16 (fig. 16)

$\begin{array}{llll}\text { marsh interior } & 71 & 63 & 8 \\ \text { marsh } & \underline{55} & \underline{52} & \underline{3} \\ & 16 & 11 & 5\end{array}$

marsh

55

marsh edge

3

64

$-9$

$\underline{43}$

$-17$

marsh

54

47

20

$-1$

21

8

water

$\underline{3}$

51

27

7
-17
24

59

$-5$

$-29$

marsh

52

water

$-1$

53

8

$-3$

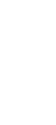

4


Table 1 continued. Adjusted depths (thickness) and NAVD88 elevations for stratigraphic contacts correlated between cores at Sabine National Wildlife Refuge.

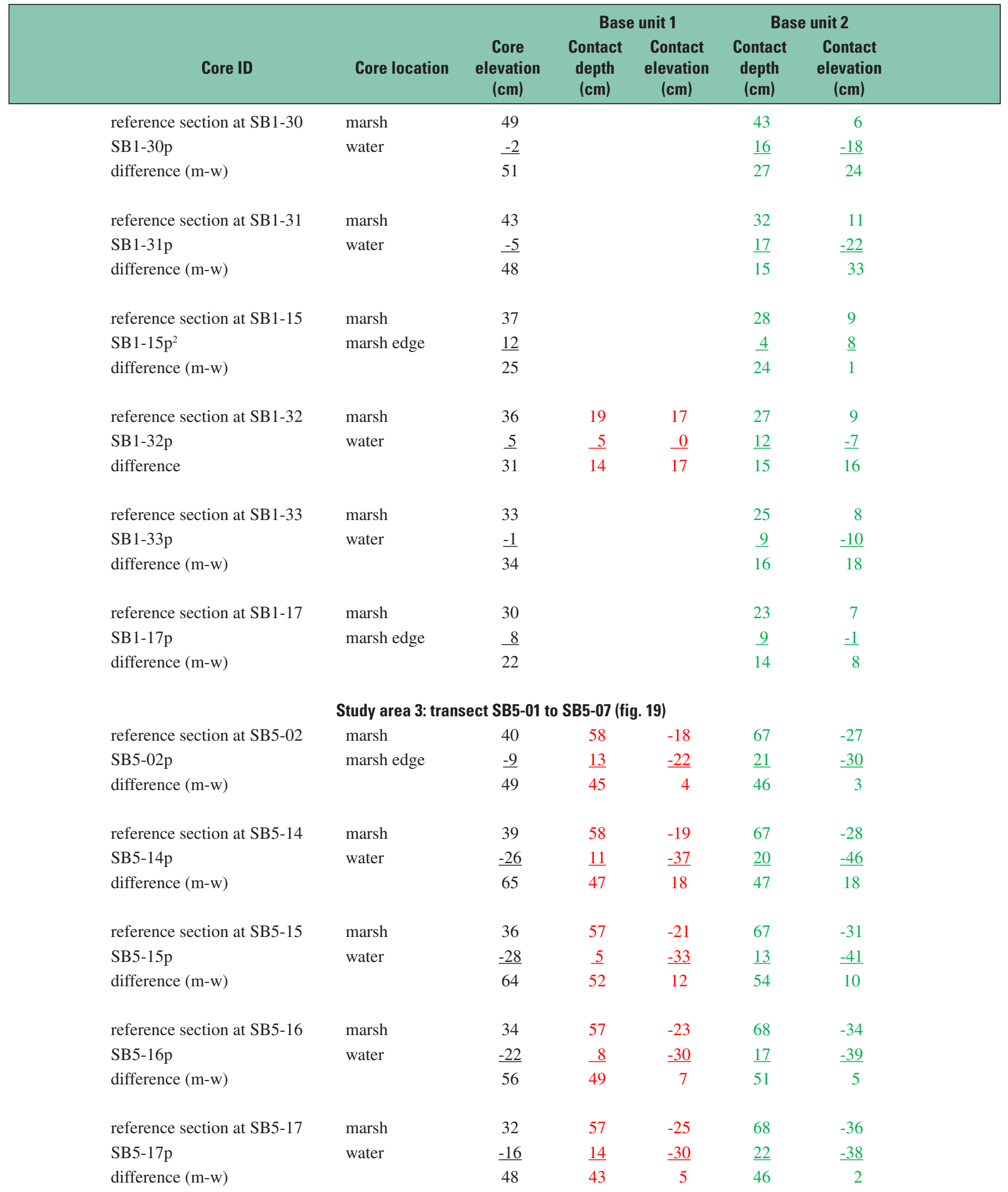


Table 1 continued. Adjusted depths (thickness) and NAVD88 elevations for stratigraphic contacts correlated between cores at Sabine National Wildlife Refuge.

\begin{tabular}{|c|c|c|c|c|c|c|}
\hline \multirow[b]{2}{*}{ Core ID } & \multirow[b]{2}{*}{ Core location } & \multirow[b]{2}{*}{$\begin{array}{c}\text { Core } \\
\text { elevation } \\
\text { (cm) }\end{array}$} & \multicolumn{2}{|c|}{ Base unit 1} & \multicolumn{2}{|c|}{ Base unit 2} \\
\hline & & & $\begin{array}{l}\text { Contact } \\
\text { depth } \\
\text { (cm) }\end{array}$ & $\begin{array}{l}\text { Contact } \\
\text { elevation } \\
\text { (cm) }\end{array}$ & $\begin{array}{l}\text { Contact } \\
\text { depth } \\
\text { (cm) }\end{array}$ & $\begin{array}{l}\text { Contact } \\
\text { elevation } \\
\text { (cm) }\end{array}$ \\
\hline reference section at SB5-04 & marsh & 30 & 57 & -27 & 68 & -38 \\
\hline SB5-04p & marsh edge & $\underline{-9}$ & $\underline{20}$ & $\underline{-29}$ & $\underline{29}$ & $\underline{-38}$ \\
\hline difference $(m-w)$ & & 39 & 37 & 2 & 39 & 0 \\
\hline reference section at SB5-18 & marsh & 36 & 70 & -34 & 78 & -42 \\
\hline SB5-18p & water & $\underline{-8}$ & $\underline{31}$ & $\underline{-39}$ & $\underline{38}$ & $\underline{-46}$ \\
\hline difference $(\mathrm{m}-\mathrm{w})$ & & 44 & 39 & 5 & 40 & 4 \\
\hline reference section at SB5-06 & marsh & 38 & & & 83 & -45 \\
\hline SB5-05p & marsh & 38 & 75 & -37 & 83 & -45 \\
\hline SB5-07p & marsh interior & $\underline{44}$ & $\underline{80}$ & $\underline{-36}$ & $\underline{94}$ & $\underline{-50}$ \\
\hline difference $(m-w)$ & & -6 & -5 & -1 & -11 & 5 \\
\hline \multicolumn{7}{|c|}{ Study area 3: transect SB5-08 to SB5-12 (fig. 18) } \\
\hline reference section at SB5-09 & marsh & 35 & & & 42 & -7 \\
\hline SB5-09p & marsh edge & $\underline{-4}$ & & & $\underline{14}$ & $\underline{-18}$ \\
\hline difference $(m-w)$ & & 39 & & & 28 & 11 \\
\hline reference section at SB5-23 & marsh & 35 & 36 & -1 & 46 & -11 \\
\hline reference section at SB5-21 & marsh & 36 & 52 & -16 & 62 & -26 \\
\hline SB5-21p & water & $\underline{-27}$ & 4 & $\underline{-31}$ & $\underline{15}$ & $\underline{-42}$ \\
\hline difference $(m-w)$ & & 63 & 48 & 15 & 47 & 16 \\
\hline reference section at SB5-20 & marsh & 37 & 57 & -20 & 67 & -30 \\
\hline SB5-20p & water & $\underline{-18}$ & $\underline{8}$ & -26 & 17 & -35 \\
\hline difference (m-w) & & 55 & 49 & 6 & 50 & 5 \\
\hline reference section at SB5-11 & marsh & 37 & 57 & -20 & 67 & -30 \\
\hline SB5-11p & marsh edge & $\underline{-20}$ & $\underline{19}$ & $\underline{-39}$ & $\underline{29}$ & $\underline{-49}$ \\
\hline difference (m-w) & & 57 & 38 & 19 & 38 & 19 \\
\hline reference section at SB5-19 & marsh & 38 & & & 67 & -29 \\
\hline SB5-19p & water & -7 & & & $\underline{20}$ & -27 \\
\hline difference $(\mathrm{m}-\mathrm{w})$ & & 45 & & & 47 & -2 \\
\hline
\end{tabular}


Table 1 continued. Adjusted depths (thickness) and NAVD88 elevations for stratigraphic contacts correlated between cores at Sabine National Wildlife Refuge.

\begin{tabular}{|c|c|c|c|c|c|c|}
\hline \multirow[b]{2}{*}{ Core ID } & \multirow[b]{2}{*}{ Core location } & \multirow[b]{2}{*}{$\begin{array}{c}\text { Core } \\
\text { elevation } \\
\text { (cm) }\end{array}$} & \multicolumn{2}{|c|}{ Base unit 1} & \multicolumn{2}{|c|}{ Base unit 2} \\
\hline & & & $\begin{array}{c}\text { Contact } \\
\text { depth } \\
\text { (cm) }\end{array}$ & $\begin{array}{l}\text { Contact } \\
\text { elevation } \\
\text { (cm) }\end{array}$ & $\begin{array}{c}\text { Contact } \\
\text { depth } \\
\text { (cm) }\end{array}$ & $\begin{array}{l}\text { Contact } \\
\text { elevation } \\
\text { (cm) }\end{array}$ \\
\hline
\end{tabular}

$\begin{array}{llllllr}\text { reference section at SB5-13 } & \text { marsh } & 39 & 56 & -17 & 67 & -28 \\ \text { SB5-13p } & \text { marsh edge } & \underline{11} & \underline{34} & \underline{-23} & \underline{50} & \underline{-39} \\ \text { difference (m-w) } & & 28 & 22 & 6 & 17 & 11\end{array}$

Study area 4: transect SB5-24 to SB5-36 (fig. 21)

reference section at SB5-25

SB5-25p

difference $(\mathrm{m}-\mathrm{w})$

reference section at SB5-50

SB5-50p

difference (m-w)

reference section at SB5-49

SB5-49p

difference (m-w)

reference section at SB5-27

SB5-27p

difference $(\mathrm{m}-\mathrm{w})$

reference section at SB5-46

SB5-46 $\mathrm{p}^{2}$

difference (m-w)

reference section at SB5-45

SB5-45p

difference $(\mathrm{m}-\mathrm{w})$

reference section at SB5-44

SB5-44p

difference $(\mathrm{m}-\mathrm{w})$

reference section at SB5-29

SB5-29p

difference $(\mathrm{m}-\mathrm{w})$

reference section at SB5-43

SB5-43 $\mathrm{p}^{3}$

difference $(\mathrm{m}-\mathrm{w})$

reference section at SB5-42

SB5-42p

difference $(\mathrm{m}-\mathrm{w})$ marsh

marsh edge

47

$\underline{-16}$

63

marsh

46

water

$\underline{-21}$

67

marsh

44

water

$\underline{-19}$

63

marsh

marsh edge

marsh

water

marsh

water

marsh

water

marsh

marsh edge

marsh

water

marsh

water

42

$\underline{-16}$

58

41

$\underline{-26}$

67

40

$-14$

54

38

$\underline{-4}$

38

$\underline{22}$

16

$-21$

61

42

$\underline{-21}$

65

$\underline{10}$

55

-18
$\frac{-26}{8}$

78

21

57

$-37$

6

$-31$

$\frac{14}{63} \quad \frac{-35}{4}$

$75-31$

$\underline{18} \quad \underline{-37}$

57

6

60

$-18$

73

$-31$

$-36$

5

3

$-29$

$-32$

$-41$

$\frac{3}{58}$

62

$-22$

$\underline{10}$

$\underline{-24}$

52

2

63

$-25$

$-21$

74

$-36$

$\underline{17}$

$-4$

$\underline{27}$

47

$-31$

$-5$

64

$-26$

74

$-36$

$\underline{-28}$

$\underline{60}$

14

$-38$

$\begin{array}{lll}40 & 63 & -23\end{array}$

$-31$

$53 \quad 8$

63

$-21$

$-31$

10

\section{9}

1 
Table 1 continued. Adjusted depths (thickness) and NAVD88 elevations for stratigraphic contacts correlated between cores at Sabine National Wildlife Refuge.

\begin{tabular}{|c|c|c|c|c|c|c|}
\hline \multirow[b]{2}{*}{ Core ID } & \multirow[b]{2}{*}{ Core location } & \multirow[b]{2}{*}{$\begin{array}{l}\text { Core } \\
\text { elevation } \\
\text { (cm) }\end{array}$} & \multicolumn{2}{|c|}{ Base unit 1} & \multicolumn{2}{|c|}{ Base unit 2} \\
\hline & & & $\begin{array}{c}\text { Contact } \\
\text { depth } \\
\text { (cm) }\end{array}$ & $\begin{array}{l}\text { Contact } \\
\text { elevation } \\
\text { (cm) }\end{array}$ & $\begin{array}{l}\text { Contact } \\
\text { depth } \\
\text { (cm) }\end{array}$ & $\begin{array}{l}\text { Contact } \\
\text { elevation } \\
\text { (cm) }\end{array}$ \\
\hline
\end{tabular}

\begin{tabular}{|c|c|c|c|c|c|c|}
\hline reference section at SB5-40 & marsh & 44 & 63 & -19 & 74 & -30 \\
\hline SB5-40p ${ }^{2}$ & water & $\underline{-23}$ & 7 & $\underline{-30}$ & $\underline{16}$ & $\underline{-39}$ \\
\hline difference (m-w) & & 67 & 56 & 11 & 58 & \\
\hline reference section at SB5-39 & marsh & 47 & 64 & -17 & 75 & -28 \\
\hline SB5-39p & water & $\underline{-20}$ & $\underline{9}$ & $\underline{-29}$ & $\underline{21}$ & $\underline{-41}$ \\
\hline difference (m-w) & & 67 & 55 & 12 & 54 & 1 \\
\hline reference section at SB5-38 & marsh & 49 & & & 74 & -25 \\
\hline SB5-38p & water & $\underline{-26}$ & & & $\underline{10}$ & $\underline{-36}$ \\
\hline difference $(m-w)$ & & 75 & & & 64 & 11 \\
\hline reference section at SB5-37 & marsh & 51 & 64 & -13 & 75 & -24 \\
\hline SB5-37p & marsh edge & $\underline{-8}$ & $\underline{5}$ & $\underline{-13}$ & $\underline{17}$ & $\underline{-25}$ \\
\hline difference $(m-w)$ & & 59 & 59 & 0 & 28 & \\
\hline \multicolumn{7}{|c|}{ Study area 4: transect SB5-32 to SB5-30 (fig. 22A) } \\
\hline reference section at SB5-33 & marsh & 40 & 60 & -20 & 71 & -31 \\
\hline SB5-33p $\mathrm{p}^{4}$ & marsh edge & $\underline{13}$ & $\underline{2}$ & 11 & $\underline{16}$ & -3 \\
\hline difference $(\mathrm{m}-\mathrm{w})$ & & 27 & 58 & -31 & 55 & -28 \\
\hline reference section at SB5-47 & marsh & 41 & & & 72 & -31 \\
\hline SB5-47p & water & $\underline{-22}$ & & & $\underline{8}$ & $\underline{-30}$ \\
\hline difference $(m-w)$ & & 63 & & & 64 & -1 \\
\hline reference section at SB5-31 & marsh & 55 & 74 & -19 & & \\
\hline SB5-31 $p^{3}$ & marsh edge & $\underline{9}$ & $\underline{32}$ & $\underline{-23}$ & & \\
\hline difference $(m-w)$ & & 46 & 42 & 4 & & \\
\hline \multicolumn{7}{|c|}{ Study area 4: transect SB5-34 to SB5-40 (fig. 22B) } \\
\hline reference section at SB5-40 & marsh & 44 & 63 & -19 & & \\
\hline SB5-35 $\mathrm{p}^{3}$ & marsh edge & $\underline{-8}$ & $\underline{10}$ & $\underline{-18}$ & & \\
\hline difference $(\mathrm{m}-\mathrm{w})$ & & 52 & 53 & -1 & & \\
\hline reference section at SB5-40 & marsh & 44 & 63 & -19 & & \\
\hline SB5-41 ${ }^{3}$ & water & $\underline{-24}$ & $\underline{5}$ & $\underline{-29}$ & & \\
\hline difference $(m-w)$ & & 68 & 58 & 10 & & \\
\hline \multicolumn{7}{|c|}{ Study area 5: transect SB3-01 to SB3-06 (fig. 23) } \\
\hline reference section at SB3-02 & marsh & 54 & 101 & -47 & 115 & -61 \\
\hline SB3-02p & marsh edge & 9 & 40 & -31 & 59 & -50 \\
\hline difference $(m-w)$ & & $\underline{45}$ & $\underline{61}$ & $\underline{-16}$ & $\underline{56}$ & \\
\hline reference section at SB3-03 & marsh & 44 & 87 & -43 & 102 & . \\
\hline SB3-03p & water & -44 & 34 & -78 & 51 & \\
\hline difference (m-w) & & $\underline{88}$ & $\underline{53}$ & $\underline{35}$ & $\underline{51}$ & \\
\hline
\end{tabular}


Table 1 continued. Adjusted depths (thickness) and NAVD88 elevations for stratigraphic contacts correlated between cores at Sabine National Wildlife Refuge.

\begin{tabular}{|c|c|c|c|c|c|c|}
\hline \multirow[b]{2}{*}{ Core ID } & \multirow[b]{2}{*}{ Core location } & \multirow[b]{2}{*}{$\begin{array}{c}\text { Core } \\
\text { elevation } \\
\text { (cm) }\end{array}$} & \multicolumn{2}{|c|}{ Base unit 1} & \multicolumn{2}{|c|}{ Base unit 2} \\
\hline & & & $\begin{array}{c}\text { Contact } \\
\text { depth } \\
\text { (cm) }\end{array}$ & $\begin{array}{l}\text { Contact } \\
\text { elevation } \\
\text { (cm) }\end{array}$ & $\begin{array}{l}\text { Contact } \\
\text { depth } \\
\text { (cm) }\end{array}$ & $\begin{array}{l}\text { Contact } \\
\text { elevation } \\
\text { (cm) }\end{array}$ \\
\hline reference section at SB3-05 & marsh & 35 & 74 & -39 & 90 & -55 \\
\hline SB3-05p & marsh edge & 4 & 81 & -77 & 96 & -92 \\
\hline difference $(m-w)$ & & 31 & -7 & $\underline{38}$ & $\underline{-6}$ & $\underline{37}$ \\
\hline reference section at SB3-08 & marsh & 37 & 71 & -34 & 88 & -51 \\
\hline SB3-08p & water & -28 & 32 & -60 & 43 & -71 \\
\hline difference (m-w) & & $\underline{65}$ & $\underline{39}$ & $\underline{26}$ & $\underline{45}$ & $\underline{20}$ \\
\hline reference section at SB3-07 & marsh & 42 & 66 & -24 & 84 & -42 \\
\hline SB3-07p & marsh edge & $\underline{-2}$ & $\underline{52}$ & $\underline{-54}$ & $\underline{63}$ & $\underline{-65}$ \\
\hline difference $(m-w)$ & & 44 & 14 & 30 & 19 & 25 \\
\hline
\end{tabular}

${ }^{1}$ Contact at base of unit 1 is indistinct.

${ }^{2}$ Located at intersection of transects.

${ }^{3}$ Contact at base of unit 2 is indistinct.

${ }^{4}$ Excluded from figure 22A (see appendix B).

core site. The peat-thickness discrepancies are caused partly by the two different coring techniques. Vibracoring tends to compact saturated sediments, making them seem thinner than they actually are; as a result, at most vibracoring sites the core barrel penetrates deeper than the length of sediment that is recovered (Morton and White, 1997; Morton and others, 2009b). In contrast, the push corer (Jowsey, 1966) is designed to minimize sediment compaction and core shortening by cutting through the sediment after the corer is inserted to the desired sampling depth.

Compaction is estimated in the field by measuring how far the surface of the sediment in the core barrel is below the actual sediment surface. There are no standard quantitative definitions for the magnitudes of compaction. For the purposes of this report, core compaction (appendix A) is reported relative to total penetration and is defined as minor (0-10\%), moderate (11-20\%), or major (>20\%) after Morton and others (2009a). Major compaction may preclude using the stratigraphic data for quantitative analysis, depending on which stratigraphic intervals are shortened.

\section{Water-Level Measurements and Elevation Corrections}

The water depth at each coring site and at points along transects between core locations was measured with a graduated rod, while the geographic coordinates and time of each depth measurement were obtained simultaneously with a handheld GPS receiver. Water depths and marsh elevations measured in the field (table 1) can be compared only if they are corrected for any local conditions (tidal stage, wind set-up) that would influence the water-level data. Water-level fluctuations at the coring sites during field operations were assumed to be comparable to those recorded at nearby tide gages (fig. 3 and Morton and others, 2009b).

As part of the Coastwide Reference Monitoring System (CRMS; Steyer and others, 2003), the USGS, in cooperation with the Louisiana Office of Coastal Protection and Restoration (OCPR; formerly Louisiana Department of Natural Resources), operates a network of hydrologic gages located throughout the coastal wetlands of south Louisiana. OCPR also operates an independent network of hydrologic gages at monitoring stations located in coastal waters throughout south Louisiana. Electronic water-level data for nearby CRMS and OCPR gages were downloaded from the OCPR website (http://coastal.louisiana.gov/) and used to correct primary water depths and relative marsh elevations for the dates and times of data collection (fig. 3) to the North American Vertical Datum of 1988 (NAVD 88). Water depths measured in SNWR Management Unit 1 were corrected using data from CRMS site \#0641, located about 4.5 kilometers $(\mathrm{km})$ south of study area 2 , and OCPR coastal monitoring station \#CS02-05, located about $2 \mathrm{~km}$ north of study area 1. Water depths measured in Management Unit 5 were corrected using data from CRMS site \#0660, located between study areas 3 and 4 about $1.5 \mathrm{~km}$ northeast of study area 4 , and water depths measured in Management Unit 3 were corrected using data from CRMS site \#0694, located about $3.5 \mathrm{~km}$ southeast of study area 5 (fig. 1). 

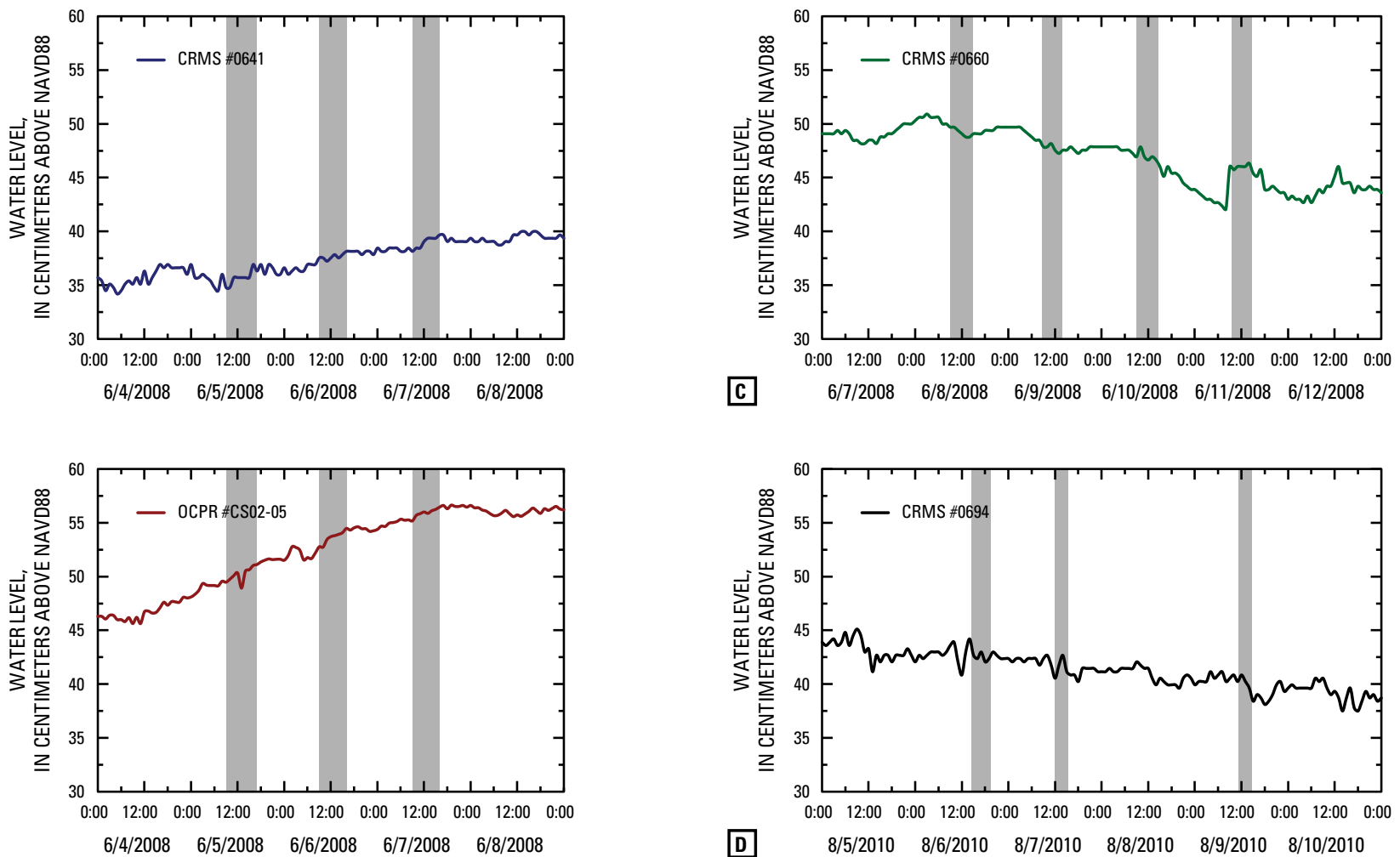

Figure 3. Water levels recorded at (A) Coastwide Reference Monitoring System (CRMS) site \#0641 on June 4-8, 2008, (B) Louisiana Office of Coastal Protection and Restoration (OCPR) coastal monitoring station \#CS02-05 on June 4-8, 2008, (C) CRMS site \#0660 on June 7-12, 2008, and (D) CRMS site \#0694 on August 5-10, 2010. Phases of the tides during field operations are highlighted (in gray). Gage locations are shown on figure 1.

\section{Wetlands of the Sabine National Wildlife Refuge}

\section{Historical Land- and Water-Area Changes}

SNWR is the largest coastal-marsh refuge and wetland-management site on the gulf coast (Louisiana Coastal Wetlands Conservation and Restoration Task Force, 2002), encompassing about 125,000 acres (about $500 \mathrm{~km} 2$ ) of coastal wetlands between Sabine and Calcasieu Lakes on the Louisiana chenier plain in Cameron Parish (fig. 1). The refuge was established in 1937 and is managed by the U.S. Fish and Wildlife Service (FWS) primarily to maintain, restore, and perpetuate habitat for migratory waterfowl (U.S. Fish and Wildlife Service, 2007). SNWR is divided into several marshmanagement units (fig. 1), and water levels and salinities are intensely managed and monitored through four Coastal Wetlands Planning, Protection, and Restoration Act (CWP-
PRA) projects and 22 CRMS sites on refuge lands. Around the coring transects, control structures within canals and bayous at the eastern boundary of SNWR Management Unit 1 and the western boundary of Management Unit 5 are designed to limit the inflow of saline waters from Calcasieu and Sabine Lakes, respectively, to the interior marshes (Miller, 2003; Clark and Mazourek, 2004), and levees and rock dikes around Management Unit 3 prevent higher salinity waters from entering this hydrologically isolated freshwater impoundment (Sharp, 2003). In addition, prescribed burning is commonly used in the SNWR wetlands to control the growth of non-native plant species (U.S. Fish and Wildlife Service, 2007).

The SNWR wetlands occupy a broad, shore-parallel, topographically low area that formed between the topographically higher beach ridges along the gulf shoreline to the south and Pleistocene upland areas to the north (figs. 1 and 2). This large wetland area initially supported trapping, hunting, and fishing by native inhabitants (U.S. Fish and Wildlife Service, 2007). In the 1920s, the area was used primarily for oil-and-gas exploration, with fur trapping as a secondary economic resource. After the muskrat population 
declined in the late 1920s and early 1930s, the land surface was sold to the Federal Government (U.S. Fish and Wildlife Service, 2007).

The temporal baseline for quantifying historical land- and water-area changes in the western chenier plain, including SNWR, is 1932-34, which represents the dates of the earliest available aerial photographs and topographic maps. Britsch and Dunbar (1996) and Barras and others (2008) presented maps depicting historical wetland losses of the chenier plain for successive decadal periods. The land-water changes displayed on the published maps were supplemented for this study by visually examining aerial photographs from 1933, 1955-56, 1965, 1969, 1975, 1978, 1981, 1985, 1989, $1998,2000,2004,2005,2007$, and 2008 (table 2). One of the difficulties associated with establishing the timing of land-area change is distinguishing between apparent land loss associated with anomalous high-water conditions such as seasonal flooding or land-management operations and permanent conversion of land to water. Compared with black-and-white photography, color and color-infrared images provide greater contrasts and tonal differences that facilitate making the land and water distinctions.

\section{Sabine National Wildlife Refuge Management Unit 1}

SNWR Management Unit 1 (figs. 1 and 4) occupies the northeast corner of the refuge. Both the 1933 and 1955-56 images show mostly continuous wetland vegetation around the Unit 1 core transects and northward-flowing dendritic channels with a parallel zone of wet marsh (the marsh surface is submerged but still visible; Morton and others, 2005; Bernier and others, 2006) between the transects (fig. 5A). By 1965 , marshes around the transects were fragmented by small water bodies (fig. 5B). Wetland loss consisted of orthogonalelongate ponds and amorphous ponds, which were possibly the result of Hurricane Carla (Morton and Barras, in press). On both sides of Northline Canal in the northwest quadrant of Unit 1, expanses of wet marsh in the 1965 photography indicate the onset of widespread wetland loss at the Pleistocene-Holocene contact north of SNWR (fig. 2). There were sharp land-water contacts east of the Unit 1 transects and at the West Hackberry oil-and-gas field, indicating possible fault activation.

Water levels on the 1969 and 1975 images appeared to be high, and marshes around the transects were generally broken and flooded. In 1978 (fig. 5C), the marshes around study area 2 were in the wet-marsh stage, whereas marshes around study area 1 were broken. Little land loss occurred around the coring transects after 1978, although the 1998 images show continued water-body enlargement and deepening across Northline Canal along the northern Unit 1/SNWR boundary. After 1998, there was little additional land-water change except for a dense network of northwest-southeast oriented braided channels and orthogonal-elongate ponds with peripheral drainage east of Beach Canal (fig. 5D) that were eroded by the 5- to 6-m wind-driven surge of Hurricane Rita (Barras, 2006). Beginning in 2005, marsh-restoration terraces were constructed in

Table 2. Types and sources of imagery used to investigate land-water changes in the Sabine National Wildlife Refuge and surrounding areas.

[DOQQ, Digital Orthophoto Quarter Quadrangle; NAPP, National Aerial Photography Program; NAIP, National Agriculture Imagery Program; NHAP, National High Altitude Photography]

\begin{tabular}{lll|}
\hline \multicolumn{1}{|c|}{ Year } & \multicolumn{1}{c|}{ Type } & \multicolumn{1}{c|}{ Imagery Source } \\
\hline 1933 & Black and white & Edgar Tobin Aerial Surveys \\
$1955-1956$ & Black and white & Edgar Tobin Aerial Surveys \\
1965 & Black and white & Edgar Tobin Aerial Surveys \\
1969 & Black and white & U.S. Army Corps of Engineers \\
1975 & Black and white & U.S. Geological Survey \\
1978 & Color-infrared & National Aeronautics and Space Administration \\
1981,1983 & Color-infrared & U.S. Geological Survey (NHAP) \\
1985 & Color-infrared & National Aeronautics and Space Administration \\
1989 & Color-infrared & U.S. Department of Agriculture (NAPP) \\
1998 & Color-infrared & Louisiana Oil Spill Coordinator's Office (DOQQ) \\
2000 & Black and white & Louisiana Department of Natural Resources \\
2004 & Color-infrared & U.S. Geological Survey (DOQQ) \\
2005 & Color-infrared & U.S. Geological Survey (DOQQ) \\
2007 & Color & U.S. Department of Agriculture (NAIP) \\
2008 & Color-infrared & U.S. Geological Survey (DOQQ) \\
\hline
\end{tabular}




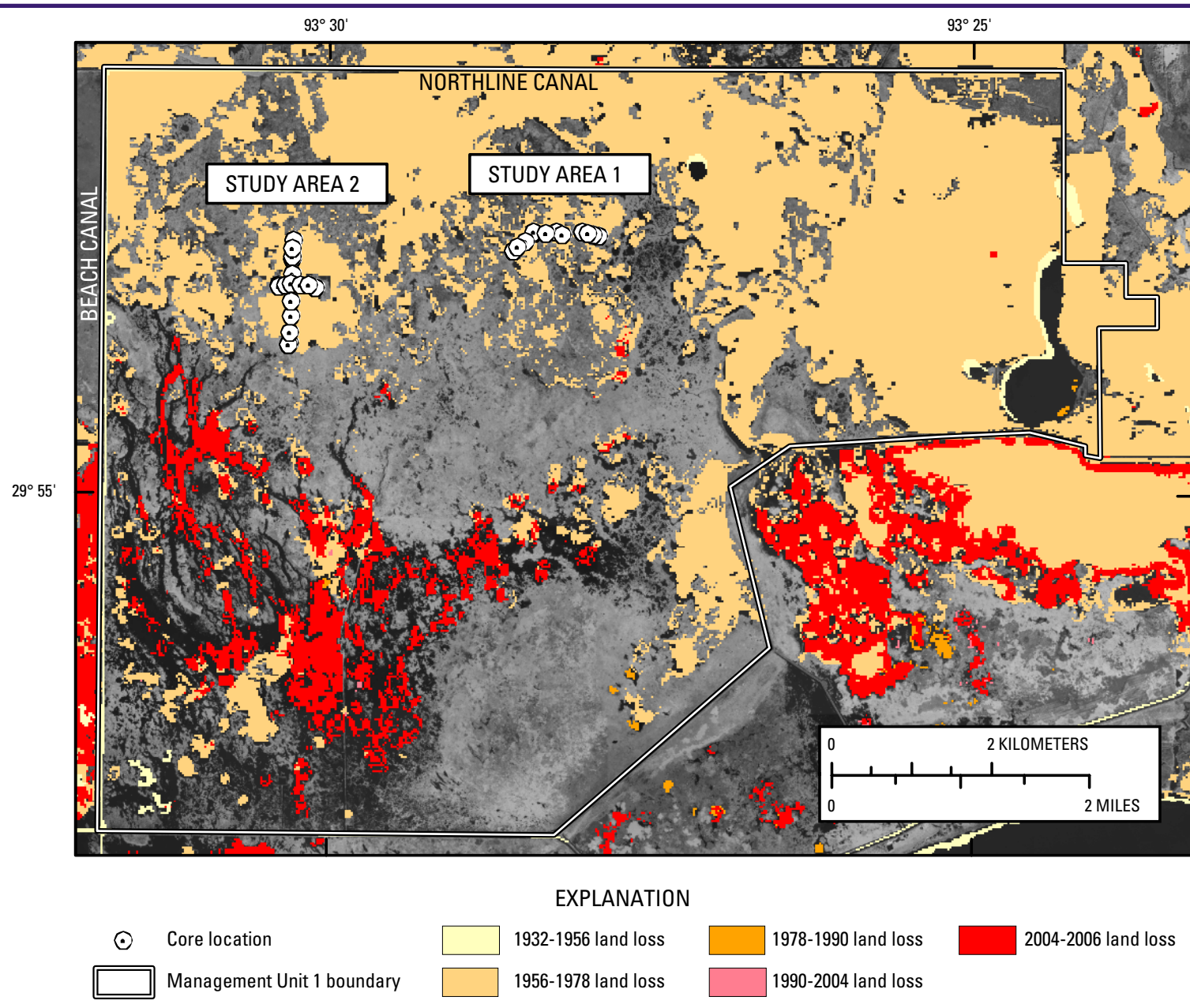

Figure 4. Map of Sabine National Wildlife Refuge (SNWR) Management Unit 1 showing locations of coring sites and historical landloss trends between 1932 and 2006. Wetland-loss trends from Barras and others (2008) and John Barras (USGS, written commun., 2008); USGS Digital Orthophoto Quarter Quadrangle (DOQ0) source imagery acquired November 18-19, 2008; display uses band 4 (near-infrared).

large water bodies north of Northline Canal. By 2007, some water bodies had enlarged and coalesced, and some marshrestoration terraces had been constructed in the large openwater body formed by subsidence around the Hackberry field.

\section{Sabine National Wildlife Refuge Management Unit 3}

SNWR Management Unit 3 (figs. 1 and 6) occupies the north-central part of the refuge. The 1933 and 1955-1956 images show that narrow canals and levees impounded what is now Unit 3, and the wetland vegetation was continuous, except for a cluster of permanent water bodies in the southeastern quadrant known as Five Lakes (fig. 7A). The vegetated surface had a mottled appearance and there were a few small ponds. The natural marsh drainage was not well developed except for a northward-flowing dendritic channel in the northwest corner of Unit 3 and a southwest-flowing channel (Old North Bayou) draining Five Lakes. Small ponds and areas of greater marsh wetness were concentrated in the northern half and southeastern quadrant of the impoundment.

By 1965, there was extensive wetland loss covering most of the southeastern quadrant of Unit 3. There was also extensive flooding of broken, fragmented marsh in the northwestern quadrant, and a band of wetland loss near and parallel to the northwestern levee (fig. 7B). In 1978, the extensive wetland loss covering most of the southeastern quadrant of the impoundment persisted (fig. 7C). Little permanent land loss occurred in Unit 3 after 1978, although the extent of drowned marsh in the northwestern quadrant has fluctuated since 1998. Storm surge associated with Hurricanes Rita and Ike in 2005 and 2008, respectively, flooded the emergent marshes in the southern half of Unit 3 (fig. 7D).

\section{Sabine National Wildlife Refuge Management Unit 5}

SNWR Management Unit 5 (figs. 1 and 8) borders the eastern shoreline of Sabine Lake in the northwest part of the 

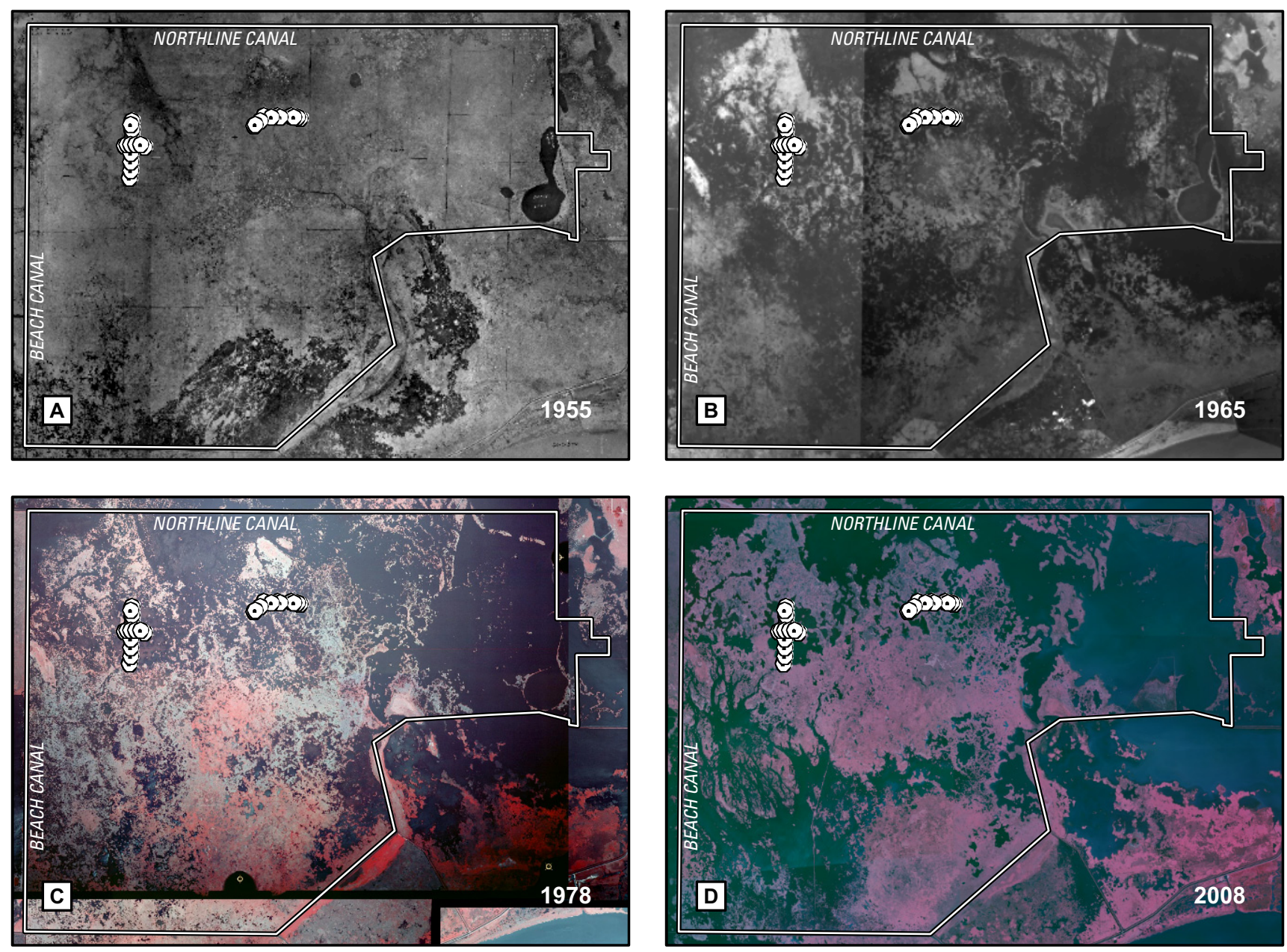

EXPLANATION

$\odot$ Core location $\square$ Management Unit 1 boundary

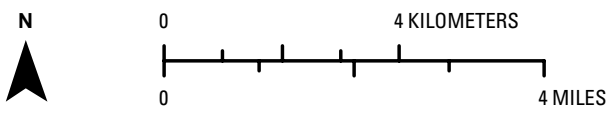

Figure 5. Locations of sediment cores at Sabine National Wildlife Refuge (SNWR) Management Unit 1 superimposed on pre- and post-land-loss aerial photographs taken in (A) 1955, (B) 1965, (C) 1978, and (D) 2008. Image sources are (A) Edgar Tobin Aerial Surveys controlled aerial mosaics, source imagery acquired October 1955; (B) Edgar Tobin Aerial Surveys black-and-white aerial photography, source imagery acquired January 27, 1965; (C) National Aeronautics and Space Administration (NASA) color-infrared aerial photography, source imagery acquired October 10, 1978; and (D) USGS Digital Orthophoto Quarter Quadrangles (D000), source imagery acquired November 18-19, 2008; RGB visual display uses bands 4 (near-infrared), 3 (red), and 2 (green).

refuge. In 1933 and 1955-56, the marsh vegetation in Unit 5 was continuous except for Greens Lake and associated channels (fig. 9A). The vegetated surface had a mottled appearance, indicating greater moisture around small ponds. Short dendritic channels drained into Greens Lake, and Greens Bayou flowed from Greens Lake into Black Bayou, but there was no other natural integrated surface-channel network. Marsh drainage was not well developed south of Greens Lake. Because water levels were slightly higher in 1965, small ponds, drainage channels, and tracks of geophysical surveys crossing the marsh were prominent. A few orthogonalelongate ponds with marginal incised drainage formed west and northwest of study area 4. However, the marshes around the transects and Greens Lake were still unbroken (fig. 9B).

Water levels also were high on the 1969 image and marshes were generally flooded, accentuating the slightly higher elevations of levees along the streams. Marshes south and east of Greens Lake were still unbroken, but marshes near the transects were broken and flooded. Britsch and Dunbar (1996) showed most of the land loss around Greens Lake occurring prior to 1974, with some additional loss occurring between 1974 and 1983. Using different source datasets, Barras and others (2008) showed the greatest amount of land loss in the same area occurring between 1978 and 1990 


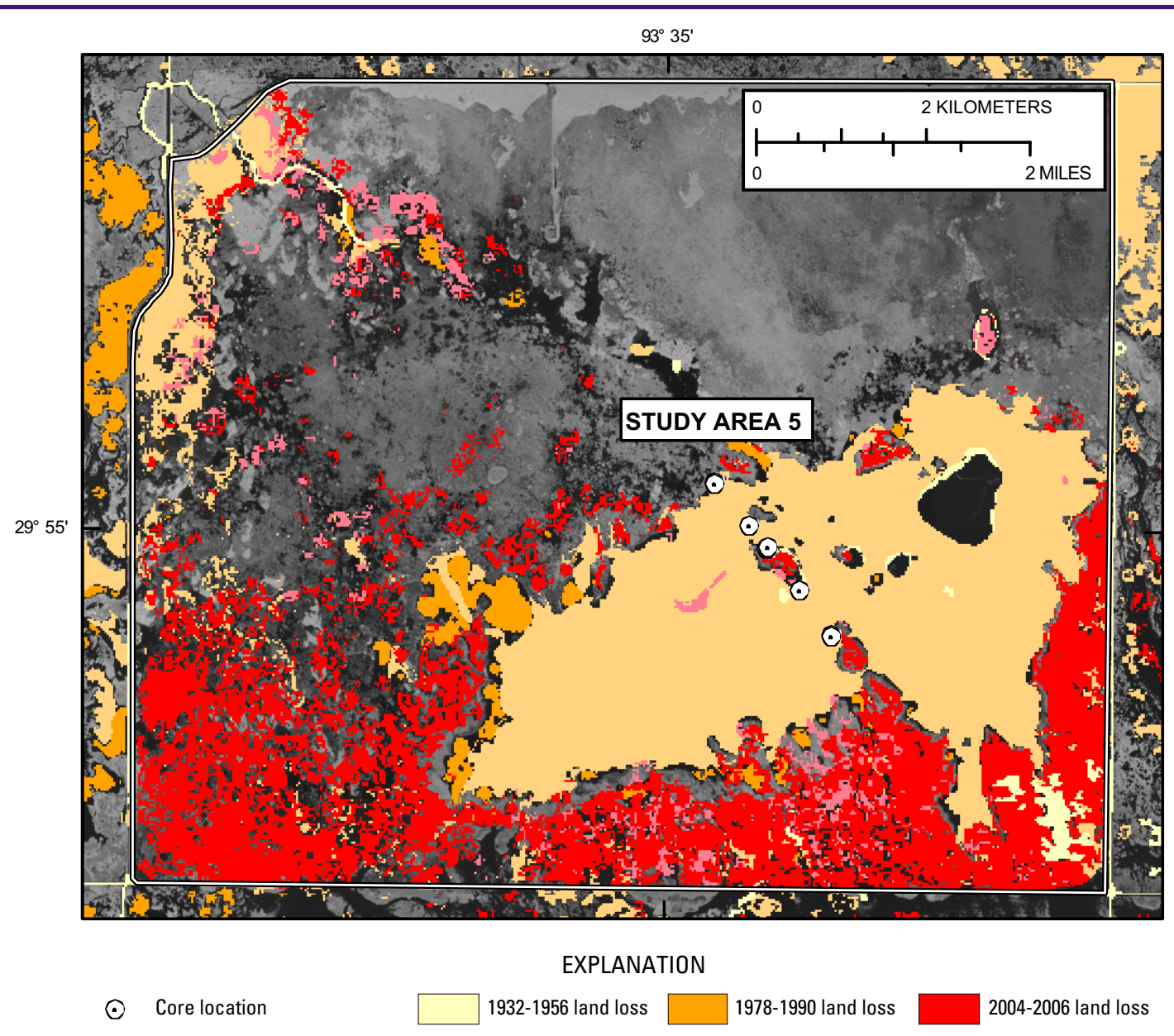

Figure 6. Map of Sabine National Wildlife Refuge (SNWR) Management Unit 3 showing locations of coring sites and historical landloss trends between 1932 and 2006. Wetland-loss trends from Barras and others (2008) and John Barras (USGS, written commun., 2008); USGS Digital Orthophoto Quarter Quadrangle (D000) source imagery acquired November 18-19, 2008; display uses band 4 (near-infrared).

(fig. 8). Visual examination of the 1970s and 1980s images showed that water levels were higher in 1975 than in 1978, when the outlines of Greens Lake and associated peripheral drainage channels were still visible but the surrounding marshes, including those surrounding the transects, were mostly inundated (fig. 9C). Between 1981 and 1989, most of the remaining areas of wet marsh became permanently submerged. By 1998, there was extensive permanent wetland loss with large water bodies occupying formerly continuous marsh. The largest area of continuous open water (approximately $13 \mathrm{~km}^{2}$ ) encompassed the former Greens Lake. After 1998, there was little land-water change. Historic land losses were less extensive north and northwest of Greens Lake, where the Pleistocene Prairie Formation crops out (fig. 8; Heinrich, 2005a).

Between 2004 and 2008, about 200,000 linear feet (about $61,000 \mathrm{~m}$ ) of vegetated terraces were constructed in the water body surrounding the former Greens Lake as part of efforts to restore the emergent wetlands. In 2008, abundant narrow orthogonal-elongate ponds with peripheral drainage formed south of study area 4 as a result of marsh erosion by Hurricane Ike (fig. 9D).

\section{Summary - Historical Wetland Losses at Sabine National Wildlife Refuge}

Most of the wetland losses in the western chenier plain, including losses around coring transects in SNWR (fig. 2), occurred between 1956-58 and 1974 (Britsch and Dunbar, 1996). Wetland loss during that period coincides with a rapid rise in relative sea level recorded at the U.S. Army Corps of Engineers (USACE) Cameron tide gage (fig. 10). Some of the wetland loss within SNWR Management Unit 3 was associated with intentional impoundment in the 1950s to create a freshwater area for wildlife habitat with an emphasis on migratory waterfowl (U.S. Fish and Wildlife Service, 2007). Additional wetland losses in the western part of Unit 3 and around Greens Lake occurred between 1974 and 1983 

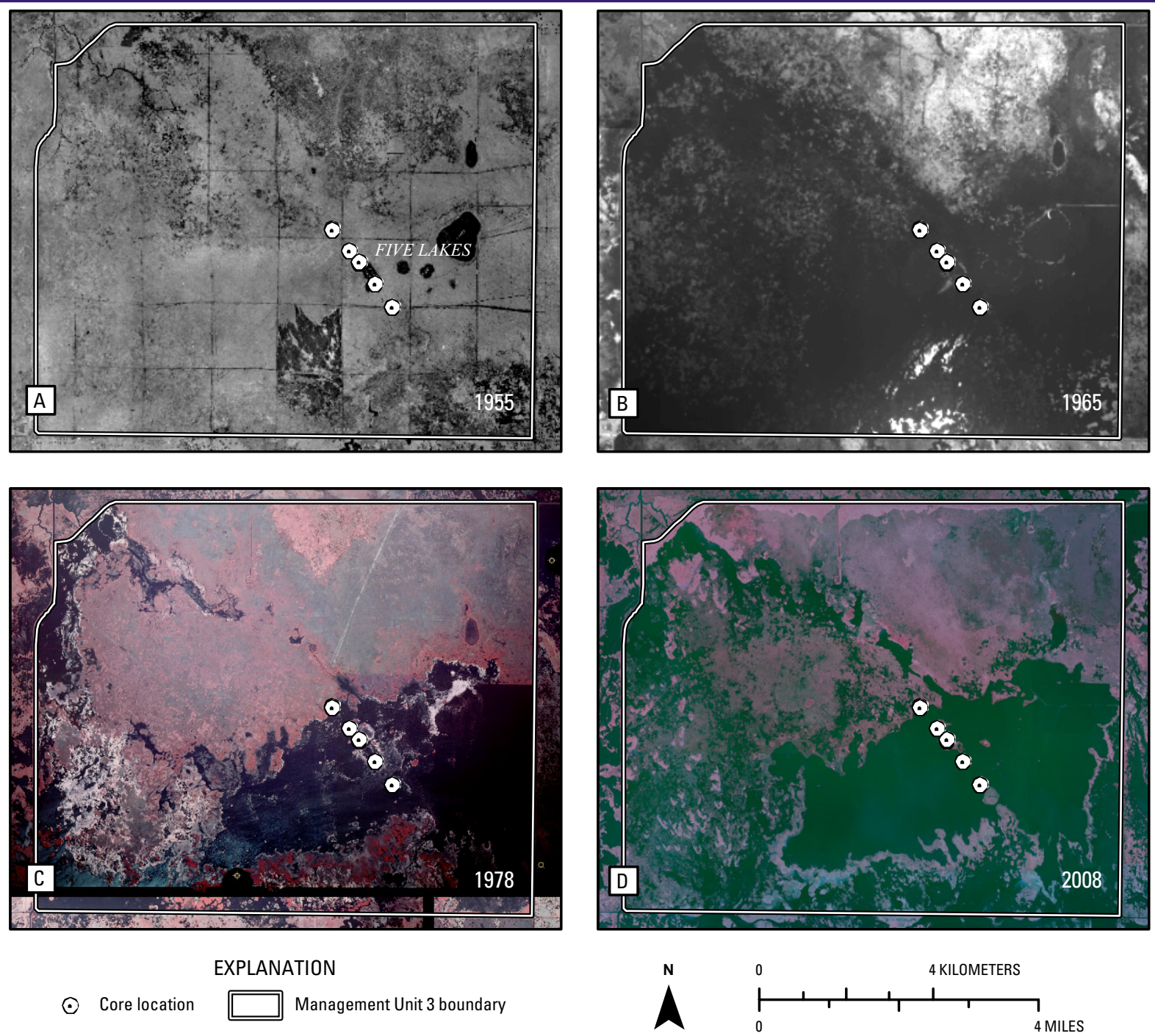

Figure 7. Locations of sediment cores at Sabine National Wildlife Refuge (SNWR) Management Unit 3 superimposed on pre- and post-land-loss aerial photographs taken in (A) 1955, (B) 1965, (C) 1978, and (D) 2008. Image sources are (A) Edgar Tobin Aerial Surveys controlled aerial mosaics, source imagery acquired October 1955; (B) Edgar Tobin Aerial Surveys black-and-white aerial photography, source imagery acquired January 27, 1965; (C) National Aeronautics and Space Administration (NASA) color-infrared aerial photography, source imagery acquired October 10, 1978; and (D) USGS Digital Orthophoto Quarter Quadrangles (D000), source imagery acquired November 18-19, 2008; RGB visual display uses bands 4 (near-infrared), 3 (red), and 2 (green).

(Britsch and Dunbar, 1996). Wetland losses since 1983 were associated primarily with storm impacts (for example, Hurricane Rita in 2005 and Hurricane Ike in 2008).

Heinrich (2005b) mapped several short fault traces visible on aerial photographs around the West Hackberry and Cameron Meadows oil-and-gas fields (fig. 2). Recent movement along these fault traces have locally influenced the historical land-water changes by increasing land subsidence and wetland losses on the downthrown side of the faults.

The difference in elevation between the topographically lower Holocene coastal-plain marshes (typically $<0.55 \mathrm{~m}$ ) and the higher Pleistocene upland surfaces (typically $>1 \mathrm{~m}$ ) helps explain some of the wetland-loss patterns. For example, subsidence around the West Hackberry oil-and-gas field caused submergence of the low wetland areas, but the slightly higher Pleistocene exposures on the southeast side of the field did not lose enough elevation to cause permanent inundation and land loss (fig. 2).

\section{Historical Changes in Wetland-Vegetation Types}

Chabreck and others (2001) and Sasser and others (2008) presented a series of coastal-wetland maps depicting vegetation types of the marshes in coastal Louisiana at decadal intervals. The sequence of maps depicting habitat shifts shows that between 1949 and 2007 some assemblages of marsh 


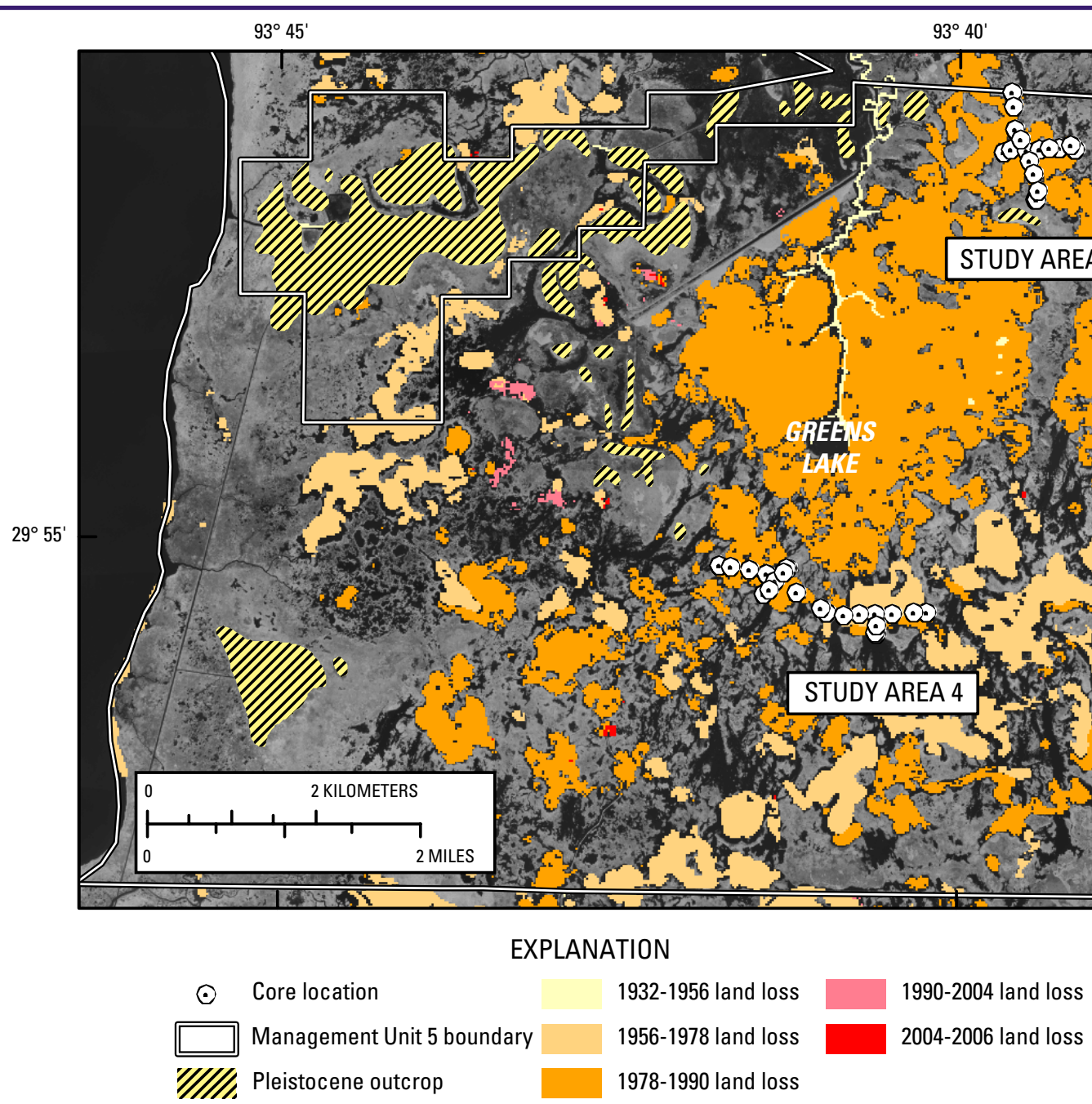

Figure 8. Map of Sabine National Wildlife Refuge (SNWR) Management Unit 5 showing locations of coring sites, Pleistocene sediments (Heinrich, 2005a), and historical land-loss trends between 1932 and 2006. Wetland-loss trends from Barras and others (2008) and John Barras (USGS, written commun., 2008); USGS Digital Orthophoto Quarter Quadrangle (D000) source imagery acquired November 18-19, 2008; display uses band 4 (near-infrared).

plants at SNWR converted to fresh marsh, whereas other plant assemblages alternated between intermediate and brackish marsh as a result of both natural variations in climate and human activities.

In 1949, before construction of the marsh-management impoundments, the marshes were classified as predominately intermediate, with some fresh marsh along the northern boundary of the refuge. By 1968, water-management practices had converted the Unit 3 impoundment to a fresh marsh, whereas the surrounding marshes in Unit 1 remained intermediate, and those of Unit 5 had converted to brackish except for those that remained intermediate around Greens Lake. The conversion of some marshes from intermediate to brackish may have been partly attributed to prolonged flooding after Hurricane Audrey in 1957 and (or) to droughts in 195657 and 1964-68. In 1978, the impounded fresh marshes of Unit 3 were surrounded by intermediate and brackish marshes in both Units 1 and 5. The greater extent of brackish marshes was probably related to lower rainfall between 1970 and 1978 . By 1988, intermediate marshes surrounding the impounded fresh marshes of Unit 3 had entirely converted to brackish marshes. However, by 1997, the same brackish marshes had reverted back to intermediate marshes at a time when there were no severe droughts or hurricane impacts in the chenier plain. In 2007, Unit 3 remained a fresh-marsh impoundment, Unit 5 remained an intermediate marsh, and Unit 1 displayed a gradient with intermediate marsh nearest to Unit 3 and brackish marsh to the east toward Calcasieu Lake (Sasser and others, 2008). The conversion of intermediate marsh to brackish marsh near Calcasieu Lake was likely related to increased salinities from the extensive saltwater flooding associated with Hurricane Rita in 2005 (Steyer and others, 2010). Considering the temporal and spatial variability of the marsh-vegetation types, it is uncertain if they were caused 

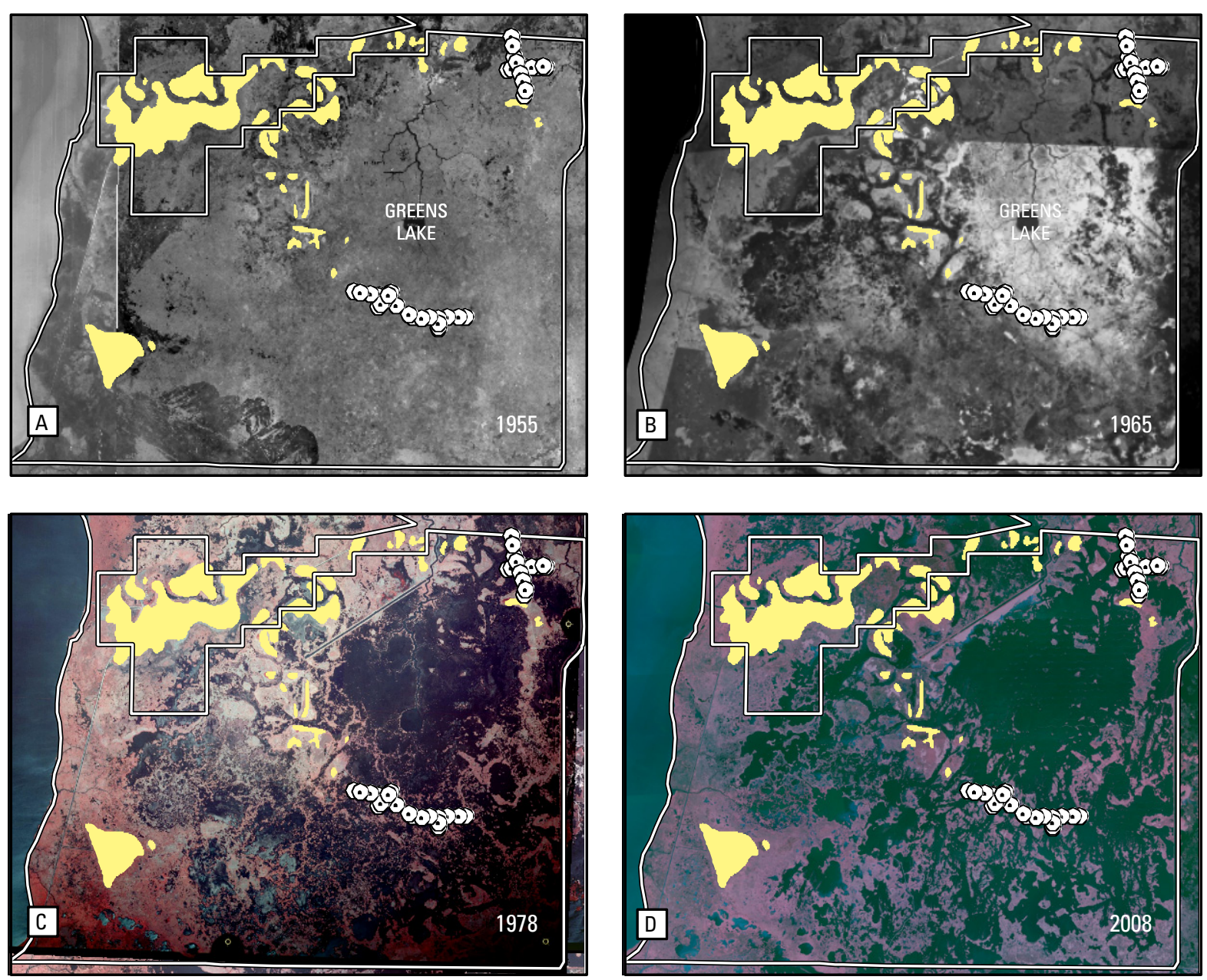

EXPLANATION
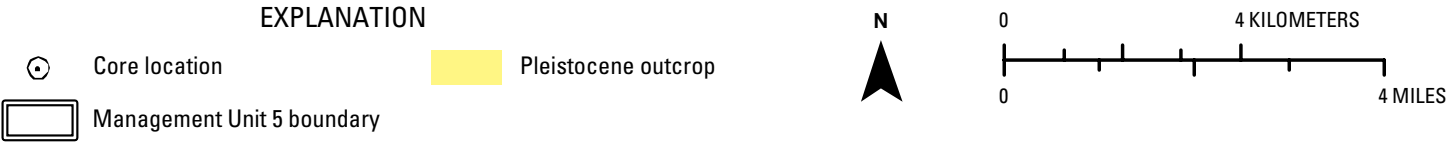

Figure 9. Locations of sediment cores and Pleistocene sediments (Heinrich, 2005a) at Sabine National Wildlife Refuge (SNWR) Management Unit 5 superimposed on pre- and post-land-loss aerial photographs taken in (A) 1955, (B) 1965, (C) 1978, and (D) 2008. Image sources are (A) Edgar Tobin Aerial Surveys controlled aerial mosaics, source imagery acquired October 1955; (B) Edgar Tobin Aerial Surveys black-and-white aerial photography, source imagery acquired January 27, 1965; (C) National Aeronautics and Space Administration (NASA) color-infrared aerial photography, source imagery acquired October 10, 1978; and (D) USGS Digital Orthophoto Quarter Quadrangles (D000), source imagery acquired November 18-19, 2008; RGB visual display uses bands 4 (near-infrared), 3 (red), and 2 (green).

mainly by climatic cycles of greater and less rainfall, storm impacts, or a combination of natural processes and human activities.

\section{Effects of Climate and Marsh Management on Wetlands}

Historical wetland loss and habitat changes from fresh to intermediate or brackish marshes in the western chenier plain have been attributed largely to saltwater intrusion and a reduction in freshwater inflow (Louisiana Coastal Wetlands Conservation and Restoration Task Force, 2002; U.S. Fish and Wildlife Service, 2007). The saltwater intrusion and associated stresses on marsh vegetation resulted from deepening of the Calcasieu Ship Channel and Sabine-Neches Waterway and subsequent salinity increases in tidal waters that flowed through the natural channels of the marshes adjacent to Calcasieu and Sabine Lakes as well as through the many interconnected manmade canals that transect the marshes. Increased wetland salinities were also attributed to construction of the Gulf Intracoastal Waterway and associated 


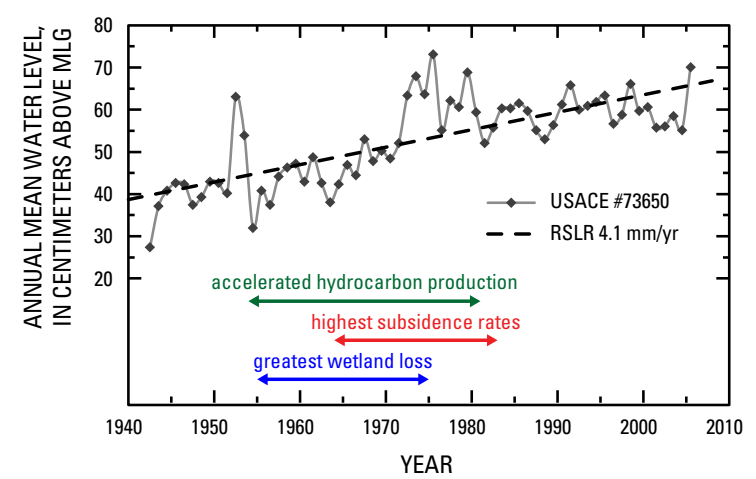

Figure 10. Linear-regression trend for mean annual water levels at Calcasieu Pass recorded at the U.S. Army Corps of Engineers Cameron tide gage (USACE \#73650) from 1942 to 2005. Also shown are the overlapping periods of highest rates of wetland loss, land subsidence, and subsurface-fluid production. Gage location is shown on figure 1. Abbreviations: MLG, Mean Low Gulf; RSLR, relative sea-level rise; $\mathrm{mm} / \mathrm{yr}$, millimeters per year.

banks of dredged material north of SNWR that impede the flow of freshwater that normally would flow southward into marshes of the refuge. Secondary factors that contributed to habitat changes and wetland loss in SNWR included surface discharge of produced formation water, the timing of stormrelated flooding by hurricanes Audrey and Carla, the 1956-57 drought, and nutria herbivory (Louisiana Coastal Wetlands Conservation and Restoration Task Force, 2002).

Early in the 20th century, extensive networks of artificial channels, known as trainasse, were dug in the coastal wetlands to promote the fur-trapping industry (Davis, 1976). These were originally narrow, shallow ditches that allowed oneway passage of a small canoe-like boat. The trainasse were later enlarged naturally by water flow and also artificially by dredging. Still later in the 20th century, the network of channels within the marsh was greatly expanded to support oil-and-gas exploration and development. Despite conventional wisdom that wetland losses were related to canal dredging, Day and others (2000) found that there was no statistically significant relation between direct wetland losses associated with canal dredging and all other wetland losses in the Calcasieu-Sabine hydrologic basin.

Levees and other structures were placed in wetlands of the chenier plain in an attempt to manage the marshes by controlling salinity and water levels. The marsh-management structures and practices have not been entirely successful in accomplishing their intended goals, which were mitigation of salt-water intrusion and reduction or prevention of wetland loss (Cowan and others, 1988). For example, impoundments may contribute to wetland loss by reducing sediment and nutrient influx (Day and others, 1990; Reed, 1992; Boumans and Day, 1994; Cahoon, 1994; Reed and others 1997; Kuhn and others, 1999), and prolonging exposure to high-water events by increasing the residence time that marshes are flooded (Flynn and others, 1999).

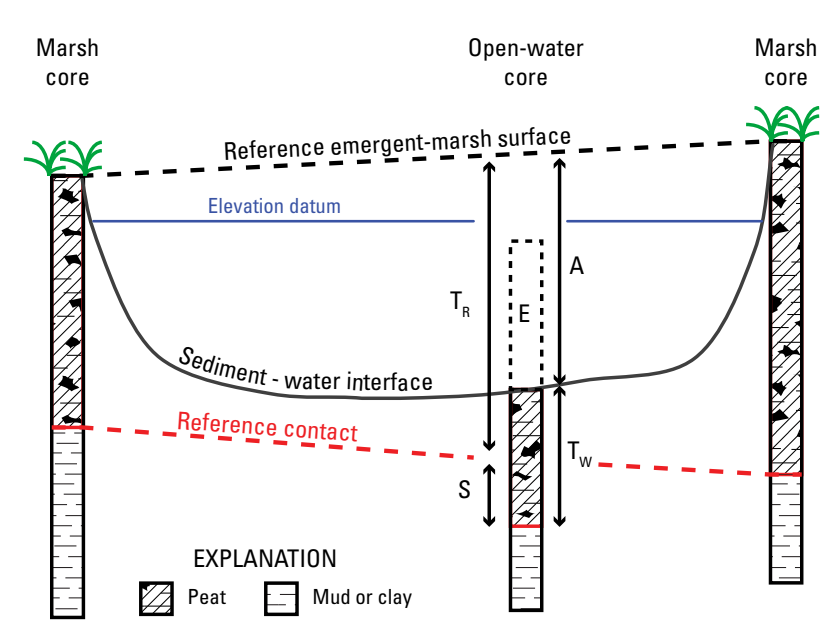

Figure 11. Conceptual diagram showing the geometric derivation of the reference stratigraphic section used to estimate the subsidence and erosion components contributing to the total one-dimensional accommodation space at an open-water core site (modified from Morton and others, 2009a). Abbreviations: A, accommodation space, $E$, erosion; $S$, subsidence, $T_{R^{\prime}}$ reference stratigraphic thickness, $T_{W^{\prime}}$ stratigraphic thickness in the openwater core.

\section{Sedimentary Facies}

Most of the cores collected at SNWR recovered a succession of unconsolidated sediments representing three or four general facies. The most common facies, from youngest to oldest, are (1) peat, (2) mud or clay, (3) interbedded lightand dark-gray clay, and (or) (4) mottled clay and silty clay. In most of the cores, contacts between facies are gradational. At the emergent-marsh sites, the youngest sediments consist of a mat of fibrous roots interspersed with water-saturated gray or brown mud associated with living Spartina sp. and Schoenoplectus $s p$. marsh-plant assemblages. The "live" roots and saturated mud indicate recent accumulation of both organic and clastic sediments. Below the most recent marsh deposits are brownish-black peat deposits with abundant root pieces that contain some dispersed mud. The abundance of visible root pieces typically decreases down-core.

The second sedimentary facies is an olive-gray mud or clay that typically contains root fragments and abundant root traces. The root traces and total organic content decrease with depth. The massive appearance of this facies is likely the result of extensive bioturbation. The deepest facies penetrated by most cores consists of mottled yellowish-orange to gray clay and silty clay. The oxidized nature of some of the facies 4 sediments indicates that they are Pleistocene. Even though there is an unconformity present, the Pleistocene-Holocene contact is gradational in most cores. At study areas 4 and 5, facies 4 was penetrated only in the vibracores and a few push cores. At these study areas, and also in some cores near the 


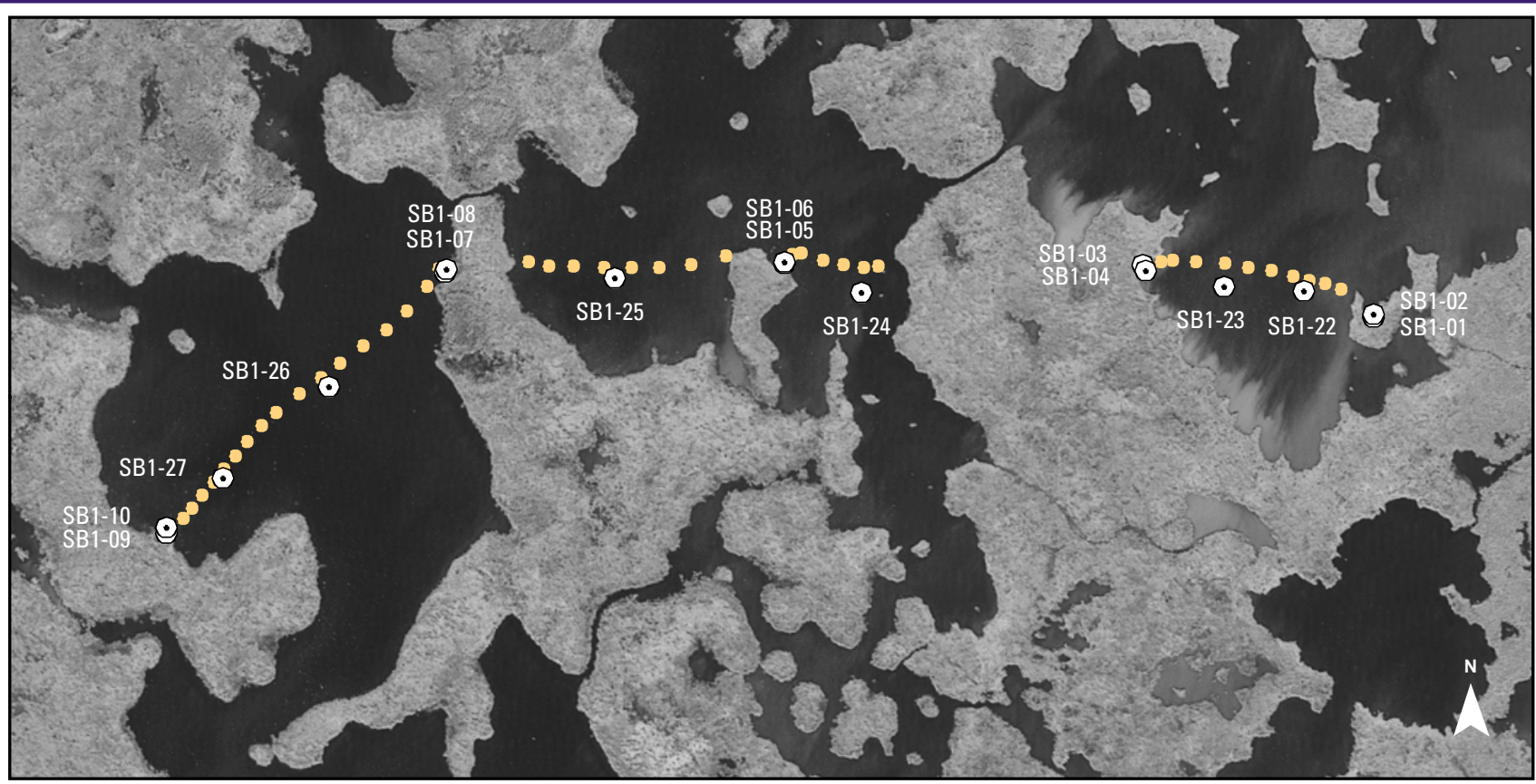

EXPLANATION

$\odot$ Core location $\bigcirc$ Measured water depth

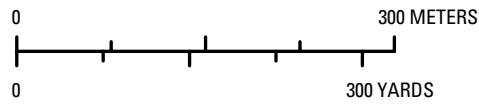

Figure 12. Locations of sediment cores and sediment-surface profiles collected at Sabine National Wildlife Refuge study area 1. USGS Digital Orthophoto Quarter Quadrangle (DO00) source imagery acquired November 18-19, 2008; display uses band 4 (nearinfrared).

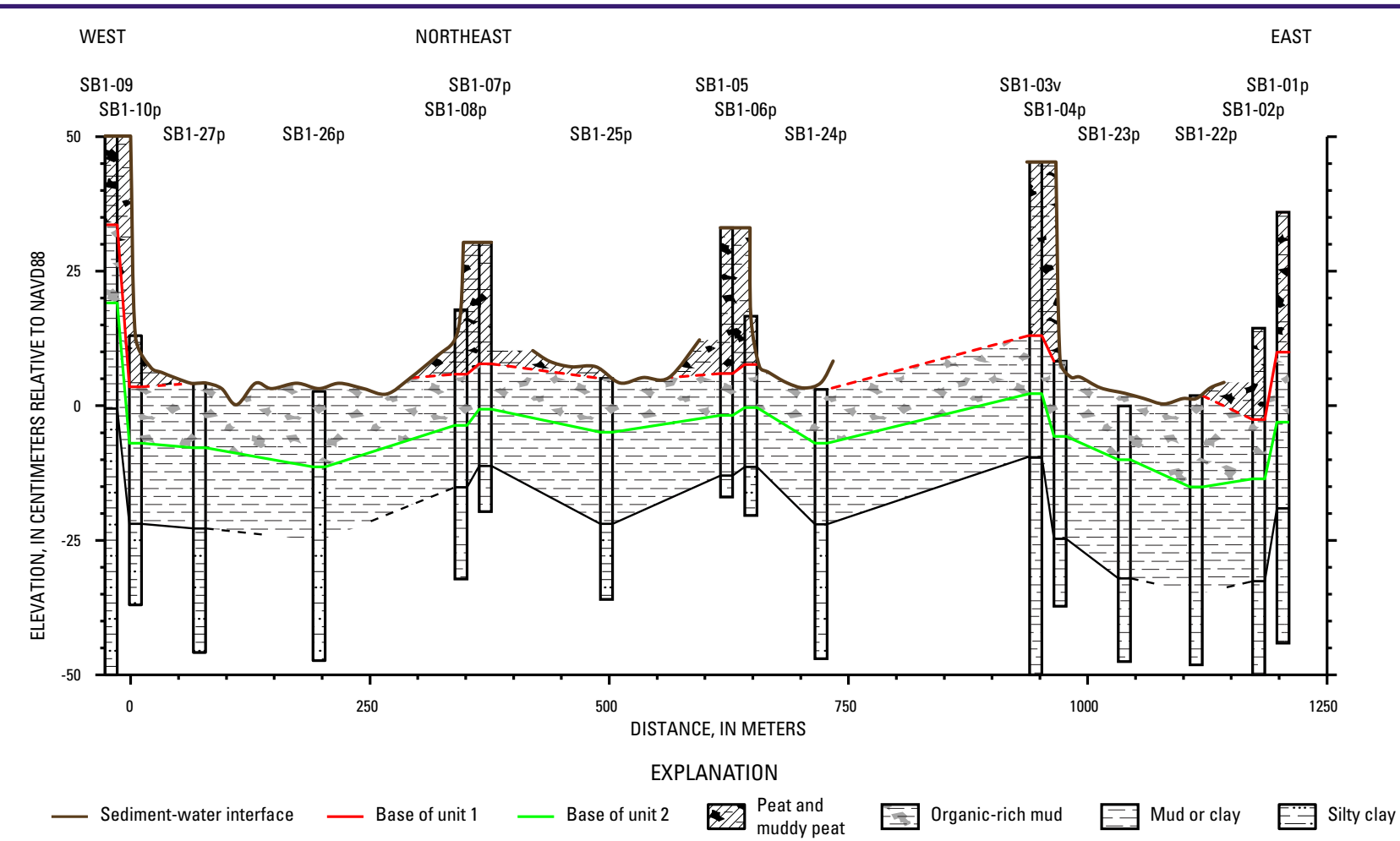

Figure 13. Combined bathymetric profile and stratigraphic cross section for marsh and open-water core sites SB1-09 to SB1-01 illustrating the magnitude of subsidence and wetland erosion (in centimeters) at study area 1. Highlighted contacts are the base of stratigraphic units 1 (in red; where present) and 2 (in green). Core locations are shown in figure 12; vertical scale is greatly exaggerated. 


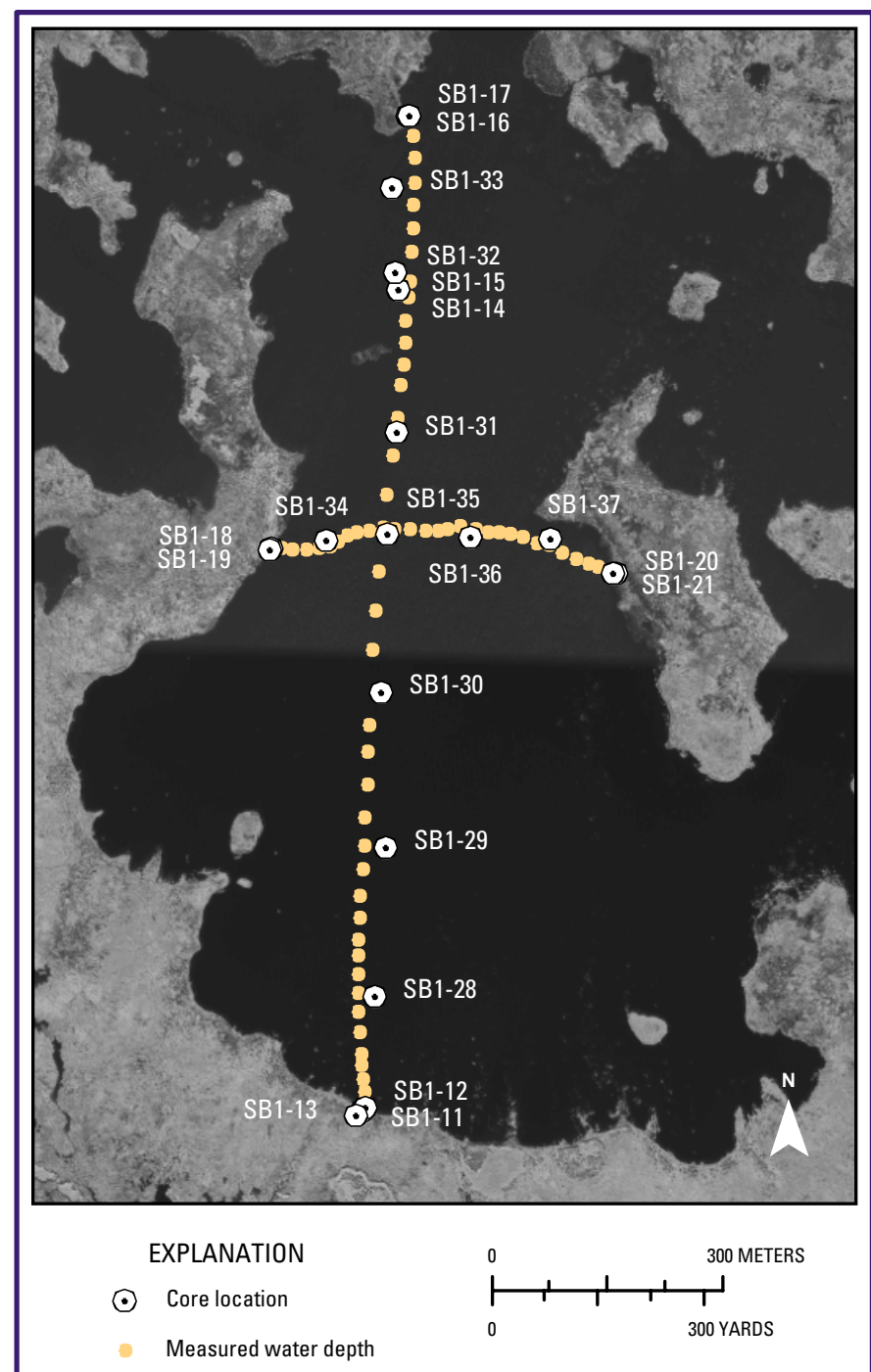

Figure 14. Locations of sediment cores and sediment-surface profiles collected at Sabine National Wildlife Refuge study area 2. USGS Digital Orthophoto Quarter Quadrangle (DOOO) source imagery acquired November 18-19, 2008; display uses band 4 (near-infrared).

center of the study area 3 open-water body, a relatively thick $(\geq 50 \mathrm{~cm})$ sequence of interbedded light- and dark-gray clay (facies 3) overlies the Pleistocene-Holocene contact below facies 2 .

\section{Historical Subsidence and Erosion of SNWR Marshes}

Morton and others (2009b) described the methodology for estimating the magnitudes of subsidence and erosion of marsh sediments within interior coastal marshes (table 1). This method assumes that emergent-marsh elevations, marsh- sediment (peat) thicknesses, and stratigraphic positions of correlated markers are uniform over short horizontal distances (tens to hundreds of meters) and compares the elevations and vertical offsets of stratigraphic contacts correlated between adjacent cores. At SNWR, however, marsh elevations and marsh-peat thicknesses at each study site varied by as much as 43 and $46 \mathrm{~cm}$, respectively. As a result, estimated magnitudes of subsidence and erosion at each open-water core site may vary significantly depending on which adjacent marsh core is used as the reference stratigraphic section.

We modified the methodology of Morton and others (2009b) and used a geometric solution to describe the reference stratigraphic section and account for natural variation in marsh-surface elevations and stratigraphic thicknesses between emergent-marsh sites along each transect. The geometric solution assumes that elevations of the marsh surface and shallow stratigraphic contacts vary linearly between adjacent marsh-core sites (fig. 11). Thus, the reference elevation of those contacts at each intervening marsh-edge or open-water core site can be determined by knowing the equation describing the change in elevation along the contact and the distance of each core site along the transect. A detailed derivation of the geometric solution for each study area is given in appendix B. The amount of erosion at an open-water core site is equal to the difference in marsh-sediment thickness between the open-water core and the reference stratigraphic section at that core site. Similarly, the amount of subsidence at an open-water core site is equal to the elevation difference of the correlated stratigraphic contact between the open-water core and the reference section at that core site. The estimates of subsidence and erosion at a core location equal the one-dimensional (vertical) accommodation space created by the land-to-water change, which is the difference between the reference marsh-surface elevation and the existing water depth at that core site.

In most cases, elevations of stratigraphic contacts from the push core collected at each emergent-marsh core site were used to define the local reference stratigraphic section. In some push cores, however, not all stratigraphic units were penetrated and (or) some stratigraphic contacts could not be resolved. In those cases, the vibracore collected at the same site was used to determine the elevations of some or all of the reference stratigraphic contacts. The linear decompaction method (Morton and others, 2009b) was used to adjust sediment-contact depths and elevations in those vibracores. Because imprecision may be introduced by gradational facies changes (up to $\pm 1-2 \mathrm{~cm}$ ) at the stratigraphic contacts and (or) by core compaction, results of the stratigraphic comparisons should be viewed as providing approximate magnitudes of subsidence and erosion (table 1) and as a way of determining the relative importance of the two processes in converting formerly emergent wetlands to open water. Whereas onedimensional accommodation measurements can be highly accurate because they only involve the difference between marsh elevations and water depths (Morton and others, 2010), subsidence and erosion estimates should not be viewed 


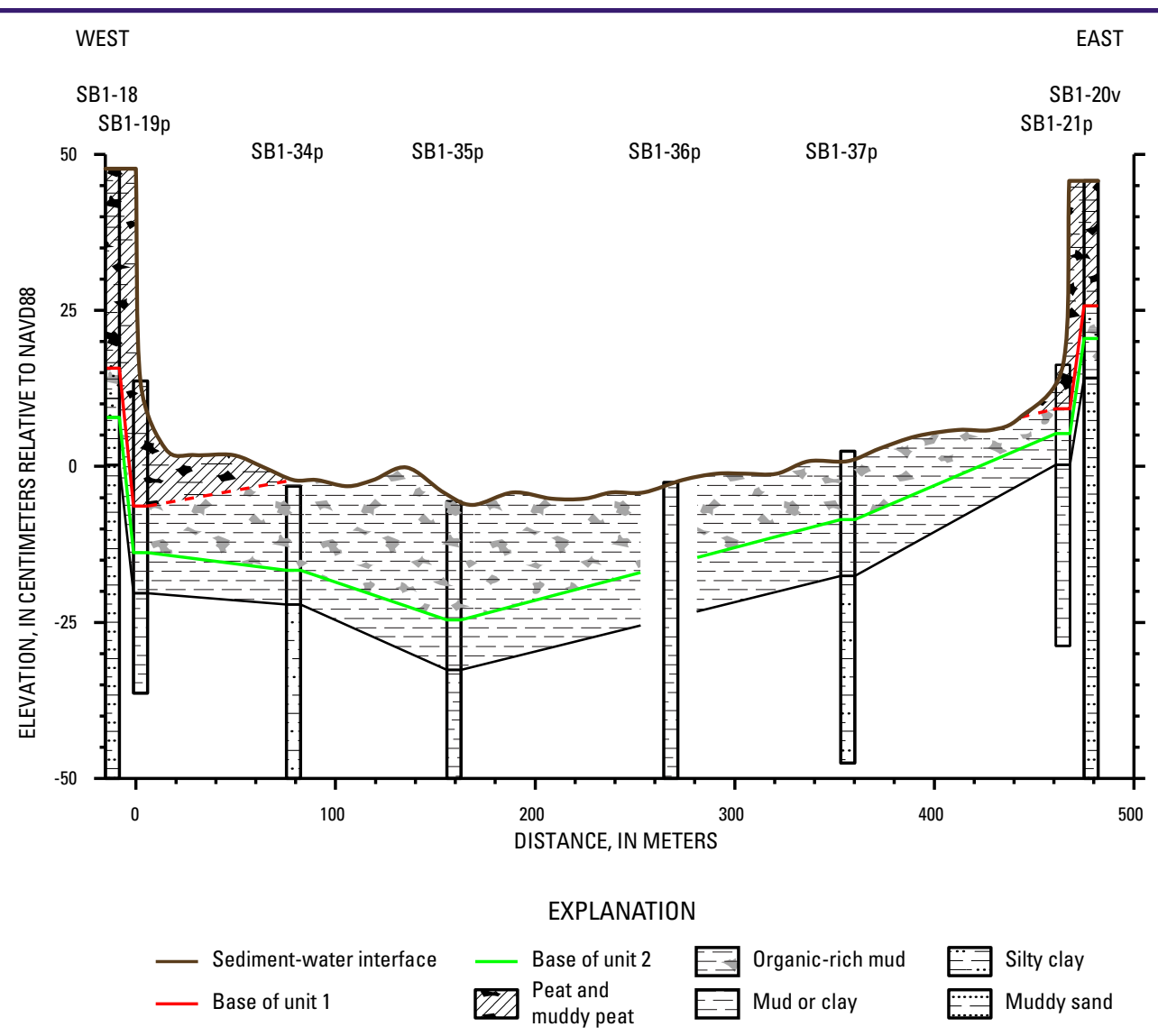

Figure 15. Combined bathymetric profile and stratigraphic cross section for marsh and open-water core sites SB1-18 to SB1-20 illustrating the magnitude of subsidence and wetland erosion (in centimeters) at study area 2. Highlighted contacts are the base of stratigraphic units 1 (in red; where present) and 2 (in green). Core locations are shown in figure 14; vertical scale is greatly exaggerated.

as absolute, highly accurate values. This is especially true at SNWR, where stratigraphic contacts in most cores are gradational and the basal peat-mud contact, which represents the establishment of the first extensive marsh and is the preferred contact to use for calculating subsidence and erosion at a core site (Morton and others, 2005; 2009a; 2009b), is not present in many of the open-water cores. As a result, in most cases, the base of the underlying organic-rich mud was used to estimate subsidence and erosion.

\section{Sabine National Wildlife Refuge Management Unit 1}

\section{Study Area 1}

The study area 1 (figs. 4 and 12) landscape in northcentral Management Unit 1 consists of highly fragmented wetlands. Five vibracores and 16 push cores were collected at 16 sites along a transect that intersected small ponds separated by remnants of the formerly continuous emergent marsh.
Marsh-surface elevations at five emergent-marsh sites range from $30 \mathrm{~cm}$ at SB1-07 to $50 \mathrm{~cm}$ at SB1-09 and average about $39 \mathrm{~cm}$. Elevations at the sediment-water interface along the study area 1 transect range from 18 to $0 \mathrm{~cm}$ and average about $6 \mathrm{~cm}$ where the marsh surface previously existed (fig. 13). Compaction of the study area 1 vibracores was minor $(2$ cores $)$ to moderate (3 cores).

The generalized stratigraphic section at study area 1 consists of four stratigraphic units: (1) peat and muddy peat, (2) organic-rich mud, (3) organic-poor clay and silty clay, and (4) mottled clay and silty clay (appendix A, cores SB1-07p and SB1-07v). Silty-to-sandy clasts and lenses are common in both stratigraphic units 2 and 3 , and those units are sandy at marsh-core site SB1-09 on the western end of the study area 1 transect. In most cores, the contacts between adjacent stratigraphic units are gradational, including the contact between units 3 and 4, which represents the transition from Holocene to Pleistocene sediments.

Peat thicknesses at the emergent-marsh sites (fig. 13) range from $16.5 \mathrm{~cm}$ at $\mathrm{SB} 1-09$ to $32 \mathrm{~cm}$ at $\mathrm{SB} 1-03$ and average about $25 \mathrm{~cm}$. Reference elevations at the base of stratigraphic units 1 and 2 increase sharply to the west from marsh-core 


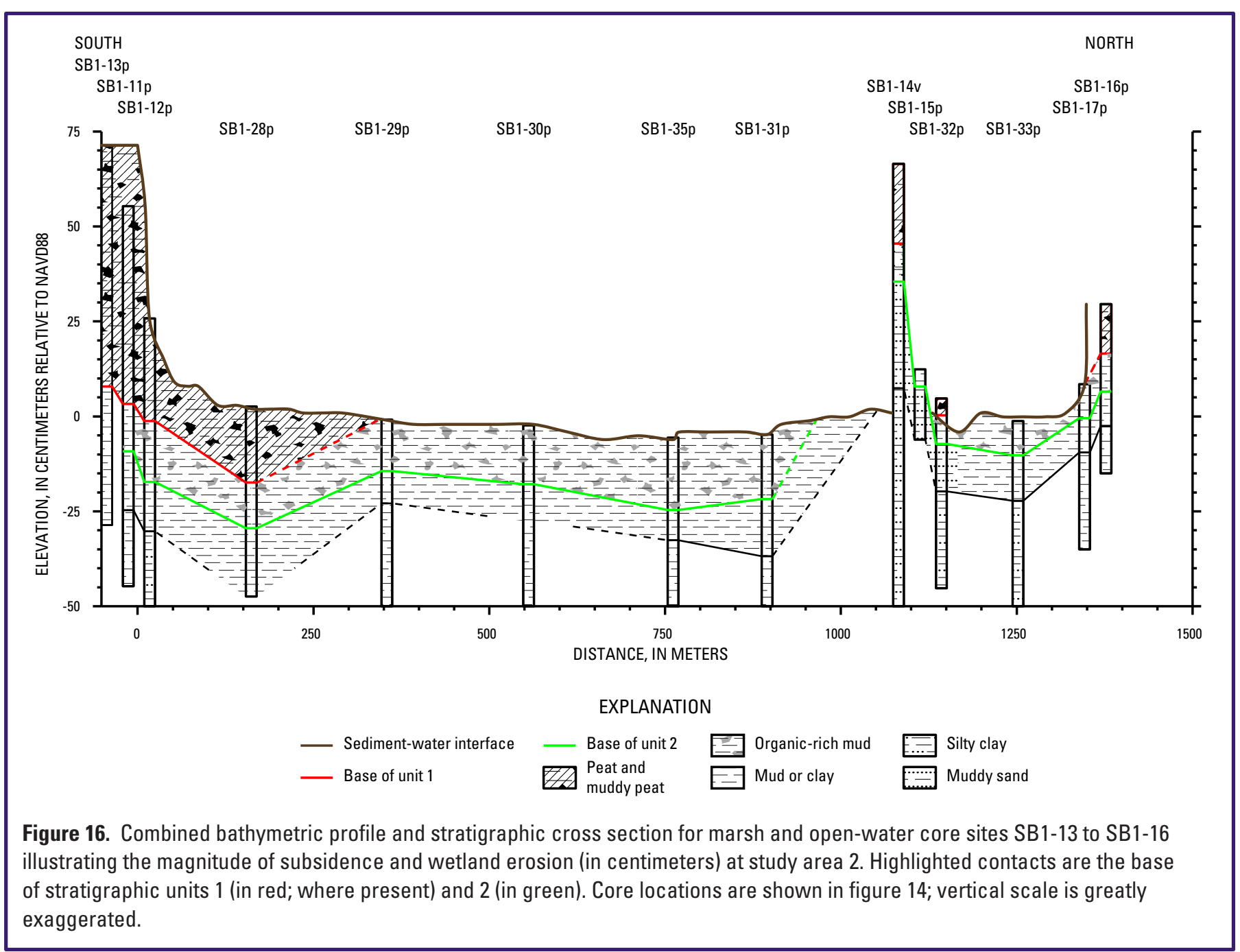

site SB1-07 toward SB1-09 (appendix B), where the marshsurface elevation is the highest and the peat thickness is thinnest of any of the study area 1 emergent-marsh sites. There is considerable relief on the Pleistocene-Holocene contact at the reference emergent-marsh sites, which decreases in elevation from west (-1 cm at SB1-09) to east (-19 cm at SB101). The thickness of the Holocene sediments at the reference emergent-marsh sites ranges from about $40 \mathrm{~cm}$ at SB1-07 to about $55 \mathrm{~cm}$ at SB1-01 and SB1-03.

The accommodation space that formed at study area 1 as a result of historic wetland loss ranged from 13 to $42 \mathrm{~cm}$ and averaged about $31 \mathrm{~cm}$. The unit 1 peat was not present in any of the open-water cores or in marsh-edge core SB104 p (fig. 13; appendix A). Using the base of stratigraphic unit 2 , erosion at the study area 1 core sites ranged from 9 to $32 \mathrm{~cm}$ and averaged about $20 \mathrm{~cm}$, whereas subsidence ranged from 0 to $26 \mathrm{~cm}$ and averaged about $11 \mathrm{~cm}$ (table 1). Erosion greatly exceeded subsidence at the open-water sites, except at SB1-26 and SB1-27, where erosion and subsidence were approximately equal. The predominance of one process over the other was more variable at the marsh-edge sites: erosion exceeded subsidence at SB1-08, SB1-06, and SB104, subsidence exceeded erosion at SB1-10, and erosion and subsidence were approximately equal at SB1-02.

\section{Study Area 2}

Five vibracores and 21 push cores were collected at 21 core sites in study area 2 (figs. 4 and 14), located about $2 \mathrm{~km}$ west of study area 1 . The study area 2 cores were collected along two intersecting transects across an approximately $1-\mathrm{km}^{2}$ open-water body. Marsh-surface elevations at five emergent-marsh sites, which generally increase from north to south, range from $30 \mathrm{~cm}$ at SB1-16 to $71 \mathrm{~cm}$ at the interiormarsh site SB1-13 and average about $53 \mathrm{~cm}$. Elevations at the sediment-water interface across study area 2 range from 26 to $-6 \mathrm{~cm}$ and average about $1 \mathrm{~cm}$ (figs. 15 and 16). Compaction of the study area 2 vibracores was minor ( 4 cores) to moderate (1 core).

The generalized stratigraphic section at study area 2 consists of four stratigraphic units: (1) peat and muddy peat, (2) organic-rich mud, (3) organic-poor clay and silty clay, and 


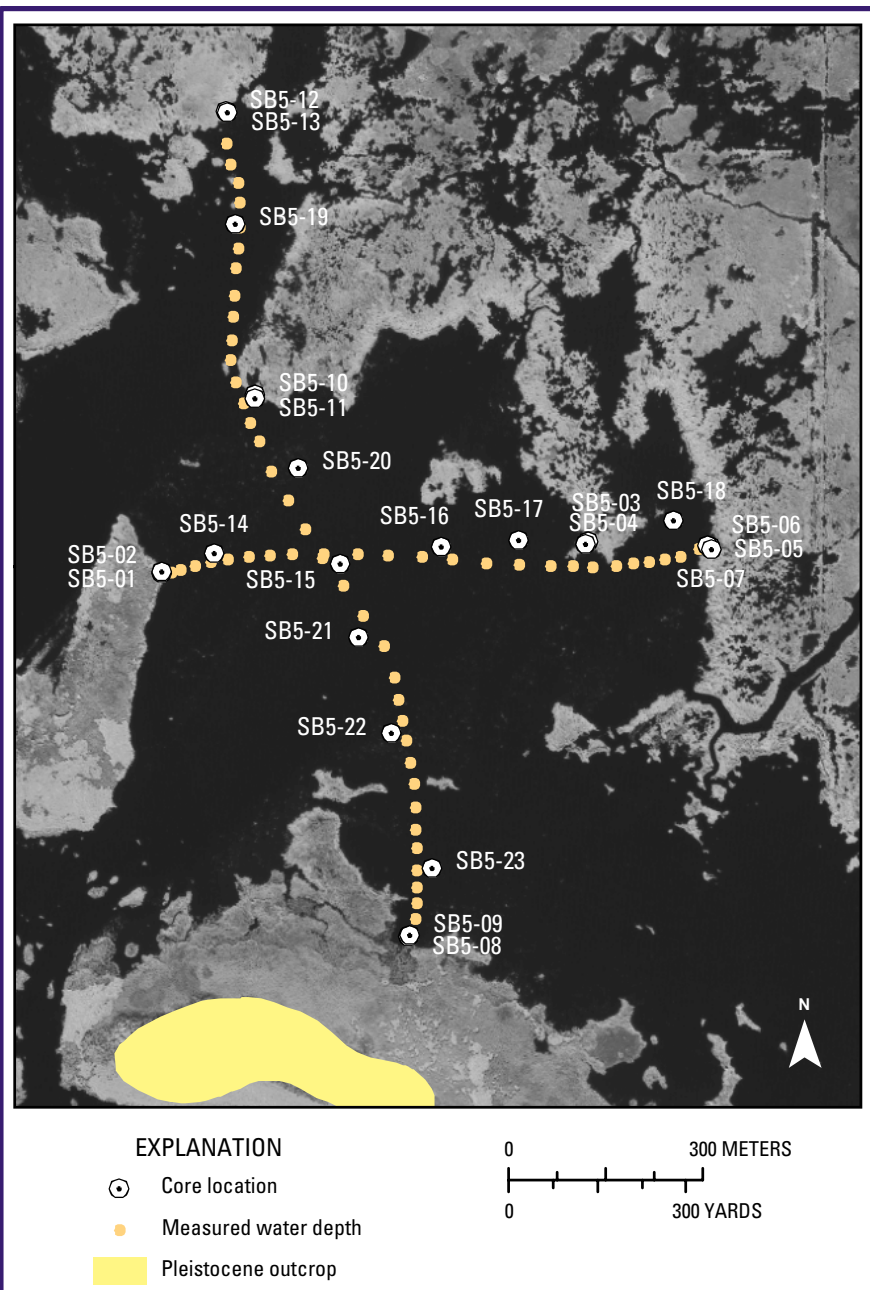

Figure 17. Locations of sediment cores and sediment-surface profiles collected at Sabine National Wildlife Refuge study area 3. USGS Digital Orthophoto Quarter Quadrangle (D000) source imagery acquired November 18-19, 2008; display uses band 4 (near-infrared).

(4) mottled clay and silty clay (appendix A, cores SB1-11p and SB1-11v). Silty-to-sandy clasts and lenses are common in both stratigraphic units 2 and 3 , or those units may be silty to sandy throughout. In most cores, the contacts between adjacent stratigraphic units are gradational.

Peat thicknesses at the study area 2 reference emergentmarsh sites (figs. 15 and 16) range from $13 \mathrm{~cm}$ at SB1-16 to $52 \mathrm{~cm}$ at SB1-11 and average about $29 \mathrm{~cm}$. Reference elevations along all stratigraphic contacts increase slightly to the east between SB1-18 and SB1-20 and decrease significantly south of this transect toward SB1-11 (appendix B).

The accommodation space that formed at study area 2 as a result of historic wetland loss ranged from 22 to $53 \mathrm{~cm}$ and averaged about $40 \mathrm{~cm}$. As at study area 1 , the unit 1 peat was not present in most of the study area 2 open-water cores or in marsh-edge cores SB1-15p and SB1-17p (figs. 15 and 16; appendix A). Using the base of stratigraphic unit 2, erosion at the study area 2 core sites ranged from 12 to $38 \mathrm{~cm}$ and averaged about $20 \mathrm{~cm}$, whereas subsidence ranged from 1 to $35 \mathrm{~cm}$ and averaged about $20 \mathrm{~cm}$ (table 1). Erosion was greater than or about equal to subsidence at most of the core sites, except at marsh-edge site SB1-19 and at sites SB1-31, SB1-35, and SB1-37 (near the center of the study area 2 open-water body), where subsidence was greater than erosion. Magnitudes of subsidence and erosion could not be estimated at SB1-36, which recovered only undifferentiated clay and silty clay (fig. 15; appendix A). At a minimum, however, all of the unit 1 peat (about $25 \mathrm{~cm}$ ) was eroded at this open-water site.

\section{Sabine National Wildlife Refuge Management Unit 5}

\section{Study Area 3}

Six vibracores and 23 push cores were collected at 23 core sites in study area 3 (figs. 8 and 17), which is located north of and separated from Greens Lake by a resistant ridge of Pleistocene outcrop. Marsh-core site SB5-08 is located along this terrain, and core sites SB5-08, SB5-09, and SB5-23 are located south of a former bayou through the study area 3 wetlands. Marsh-surface elevations at six emergent-marsh sites range from $30 \mathrm{~cm}$ at SB5-03 to $44 \mathrm{~cm}$ at the interior-marsh site SB5-07 and average about $38 \mathrm{~cm}$. Elevations at the sedimentwater interface across study area 3 range from 24 to $-36 \mathrm{~cm}$ and average about $-20 \mathrm{~cm}$ (figs. 18 and 19). With the exception of core SB5-05v, which underwent major compaction,

compaction of the study area 3 vibracores was mostly minor (2 cores) to moderate ( 3 cores).

The generalized stratigraphic section at study area 3 consists of four or five stratigraphic units: (1) peat and muddy peat, (2) organic-rich mud, (3) organic-rich to organic-poor mud, (4) interbedded light- and dark-gray clay, and (5) mottled clay and silty clay. Silty-to-sandy clasts and lenses may occur in both stratigraphic units 1 and 2. Stratigraphic unit 4 underlies unit 3 between core sites SB5-10 and SB5-22 near the center of the study area 3 open-water area (appendix A, core SB5-10v); elsewhere, stratigraphic unit 5 directly underlies unit 3 (appendix A, cores SB5-12p and SB5-12v). Unit 5 was penetrated below unit 4 only in vibracore SB5-10v. In most cores, the contacts between stratigraphic units are gradational.

Peat thicknesses at the study area 3 reference emergentmarsh core sites (figs. 18 and 19) range from $32 \mathrm{~cm}$ at SB5-08 to $75.5 \mathrm{~cm}$ at SB5-05 and average about $56 \mathrm{~cm}$. Reference elevations along the base of units 1 and 2 decrease slightly to the east between SB5-01 and SB5-05 and increase significantly south of this transect toward SB5-08 (appendix B).

The accommodation space that formed at study area 3 as a result of historic wetland loss ranged from 24 to $65 \mathrm{~cm}$ and averaged about $49 \mathrm{~cm}$. At least some peat (stratigraphic unit 
1) was present at most of the study area 3 core sites (figs. 18 and 19; appendix A), except for marsh-edge core SB5-09p and open-water core SB5-19p, where unit 1 was completely eroded. The estimated magnitudes of subsidence and erosion at each core (table 1) were similar regardless of which contact (base of unit 1 or base of unit 2) was used. Erosion at the study area 3 core sites ranged from 17 to 54 and averaged about 41 $\mathrm{cm}$, whereas subsidence ranged from 0 to $20 \mathrm{~cm}$ and averaged about $9 \mathrm{~cm}$. Erosion greatly exceeded subsidence at all study area 3 core sites.

\section{Study Area 4}

Seven vibracores and 27 push cores were collected at 27 core sites transecting open-water areas in study area 4 south of Greens Lake (figs. 8 and 20). Marsh-surface elevations at seven emergent-marsh sites range from $38 \mathrm{~cm}$ at SB5-28 to $55 \mathrm{~cm}$ at SB5-30 and average about $44 \mathrm{~cm}$. Elevations at the sediment-water interface across study area 4 range from 22 to $-37 \mathrm{~cm}$ and average about $-20 \mathrm{~cm}$ (figs. 21 and 22). Compaction of the study area 4 vibracores was minor ( 7 cores).

The generalized stratigraphic section at study area 4 consists of three stratigraphic units: (1) peat and muddy peat, (2) organic-rich mud, and (3) interbedded light- and dark- gray clay (appendix A, cores SB5-24p, SB5-29p). A fourth unit consisting of massive clay and silty clay was penetrated only in the vibracores and push core SB5-46p (appendix A). In most cores, the contacts between stratigraphic units are gradational.

Peat thicknesses at the study area 4 emergent-marsh sites (figs. 21 and 22) range from $60 \mathrm{~cm}$ at SB5-32p to $74 \mathrm{~cm}$ at SB5-30 and average about $64 \mathrm{~cm}$. Reference elevations along all stratigraphic contacts dip slightly toward SB5-28 near the center of study area 4 (appendix B).

The accommodation space that formed at study area 4 as a result of historic wetland loss ranged from 16 to $75 \mathrm{~cm}$ and averaged about $57 \mathrm{~cm}$. At least some peat (stratigraphic unit 1) was present at most of the study area 4 core sites (figs. 21 and 22; appendix A), except for open-water cores SB5-38p, SB5-47p, SB5-48p, SB5-49p, and SB5-50p, where unit 1 was completely eroded. The estimated magnitudes of subsidence and erosion at each core (table 1) were similar regardless of which contact (base of unit 1 or base of unit 2) was used. Erosion at the study area 4 core sites ranged from 14 to 64 and averaged about $52 \mathrm{~cm}$, whereas subsidence ranged from 0 to $13 \mathrm{~cm}$ and averaged about $5 \mathrm{~cm}$. The contact between stratigraphic units 2 and 3 is indistinct in core SB5-48p (fig. 22; appendix A); however, estimates of subsidence $(3 \mathrm{~cm})$ and erosion $(65 \mathrm{~cm})$ using a correlated unit 3 interbed are similar

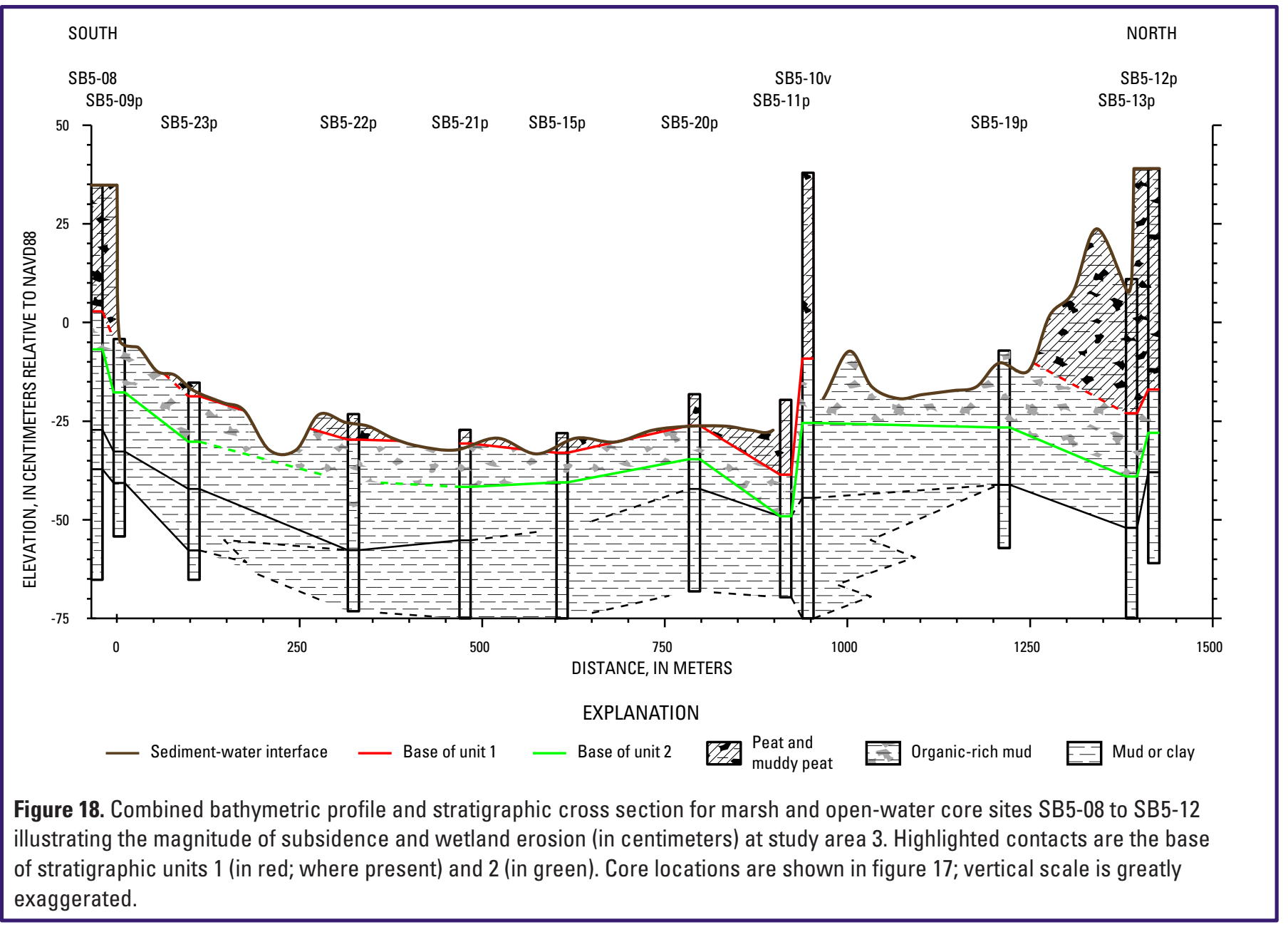




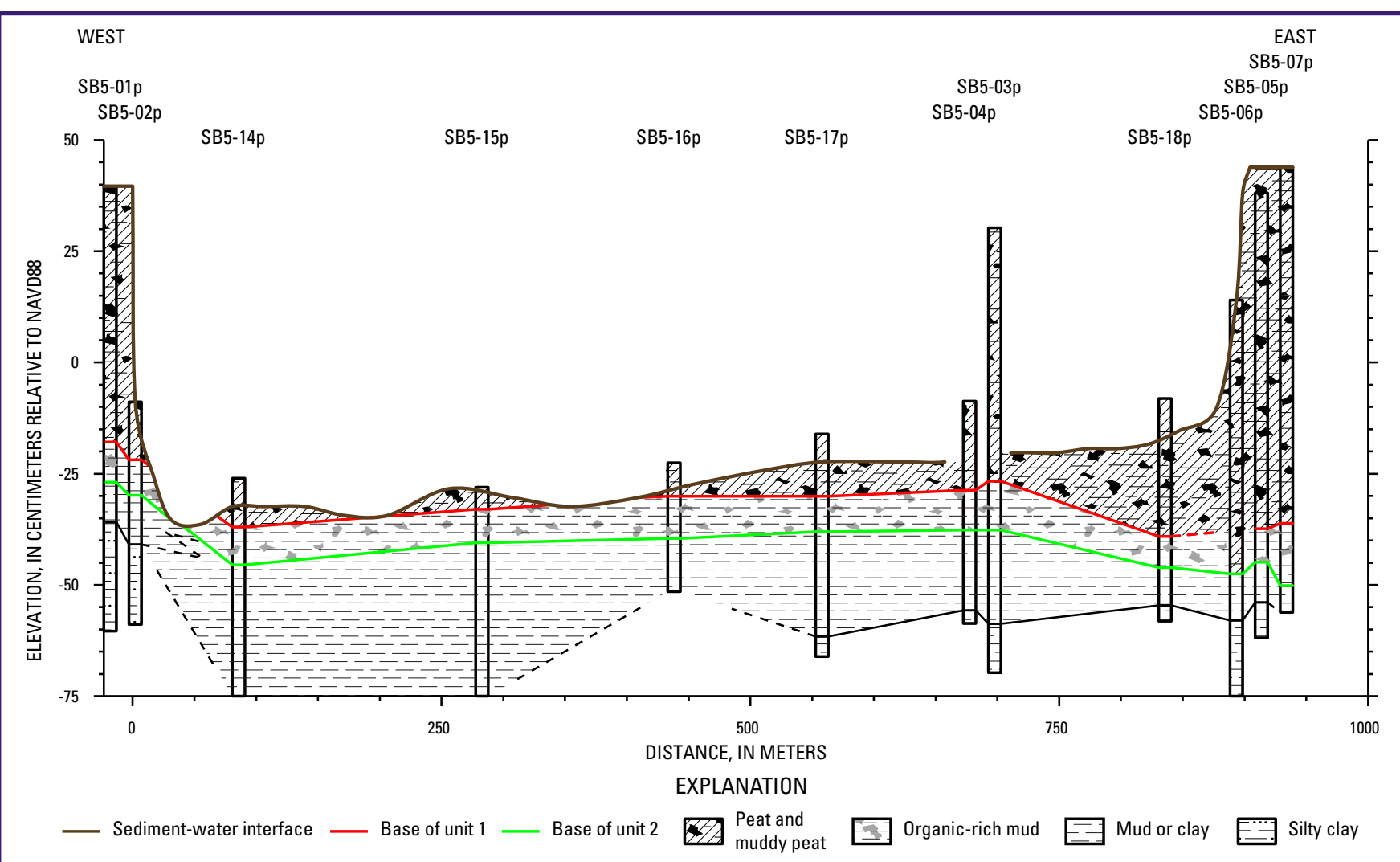

Figure 19. Combined bathymetric profile and stratigraphic cross section for marsh and open-water core sites SB5-01 to SB5-07 illustrating the magnitude of subsidence and wetland erosion (in centimeters) at study area 3 . Highlighted contacts are the base of stratigraphic units 1 (in red; where present) and 2 (in green). Core locations are shown in figure 17; vertical scale is greatly exaggerated.

in magnitude to those numbers from nearby study area 4 openwater cores. Erosion greatly exceeded subsidence at all study area 4 sites.

\section{Sabine National Wildlife Refuge Management Unit 3}

\section{Study Area 5}

Eight push cores were collected at study area 5 along a northwest-trending transect across the large open-water body in the southeastern quadrant of SNWR Management Unit 3 (figs. 6 and 23). Core sites SB3-03 and SB3-04 are located near the south and north shorelines, respectively, of one of the historic Five Lakes (fig. 7A). Marsh-surface elevations at three emergent-marsh sites range from $35 \mathrm{~cm}$ at SB3-04 to $54 \mathrm{~cm}$ at SB3-01 and average about $44 \mathrm{~cm}$. Elevations at the sedimentwater interface along the study area 5 transect range from 13 to $-45 \mathrm{~cm}$ and average about $-16 \mathrm{~cm}$ (fig. 24).

The generalized stratigraphic section at study area 5 consists of four stratigraphic units: (1) peat and muddy peat,
(2) organic-rich mud, (3) interbedded light- and dark-gray clay, and (4) silty clay (appendix A, core SB3-07p). In most cores, the contact between stratigraphic units is gradational, except for the contact between stratigraphic units 2 and 3, which generally is sharp.

Peat thicknesses at the study area 5 emergent-marsh sites (fig. 24) range from $66 \mathrm{~cm}$ at SB3-06 to $101 \mathrm{~cm}$ at SB3-01 and average about $80 \mathrm{~cm}$. Marsh-surface elevations and peat thicknesses decrease slightly along transect from southeast to northwest, whereas reference elevations along the base of stratigraphic units 1 and 2 increase slightly in the same direction (appendix B).

The accommodation space that formed at study area 5 as a result of historic wetland loss ranged from 31 to $88 \mathrm{~cm}$ and averaged about $55 \mathrm{~cm}$. The unit 1 peat was present at all of the study area 5 core sites (fig. 24; appendix A). The estimated magnitudes of subsidence and erosion at each core (table 1) were similar regardless of which contact (base of unit 1 or base of unit 2) was used. Erosion at the study area 5 core sites ranged from 0 to 61 and averaged about $32 \mathrm{~cm}$, whereas subsidence ranged from 0 to $38 \mathrm{~cm}$ and averaged about $23 \mathrm{~cm}$. Erosion exceeded subsidence at most of the core sites, except at marsh-edge sites SB3-05 and SB3-07, where subsidence exceeded erosion. 


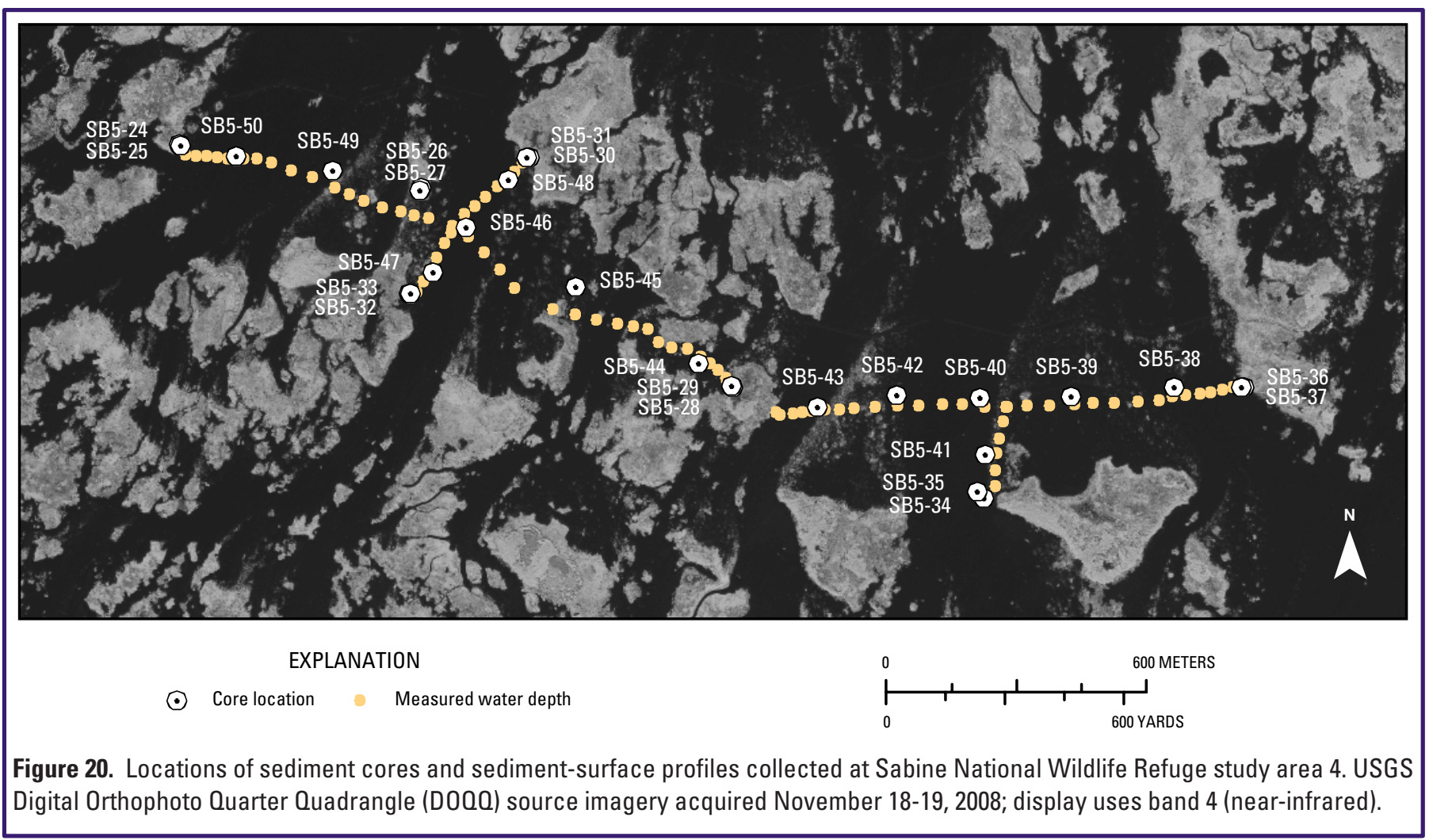

\section{Historical Land-Surface Subsidence}

One process that can cause widespread, nearly simultaneous wetland loss is land-surface subsidence. This is especially true when the elevation of the land surface is near the water table, and only a few centimeters of elevation loss can result in more frequent or permanent inundation and conversion of wetlands to open water.

Only a few data sources provide land-surface subsidence measurements at point locations in the western chenier plain; however, most of the independent data indicate "background" subsidence rates of $<6$ millimeters per year ( $\mathrm{mm} / \mathrm{yr}$ ). One of the first estimates of historical subsidence rates in the western chenier plain was $<5 \mathrm{~mm} / \mathrm{yr}$, based on geodetic leveling data and tide-gage records (Hodahl and Morrison, 1974). Recent estimates of regional land subsidence near SNWR can be derived from the closest tide gages, which are at Sabine Pass at the mouth of Sabine Lake and Cameron at the mouth of Calcasieu Lake (fig. 1). The average global rise in sea level during the past century was $1.8 \mathrm{~mm} / \mathrm{yr}$ (Douglas, 2001), and the average rate between 1993 and 2003 was $3.1 \mathrm{~mm} / \mathrm{yr}$ (Intergovernmental Panel on Climate Change, 2007), so any relative rise in sea level greater than those values should be a measure of local subsidence rates. The National Oceanic and Atmospheric Administration (NOAA) tide-gage record at Sabine Pass shows an average relative rise in sea level of $5.7 \mathrm{~mm} / \mathrm{yr}$ since the late 1950s (NOAA, 2010). Penland and Ramsey (1990) reported the same rate of relative sealevel rise for the U.S. Army Corps of Engineers tide gage at
Cameron based on a record from 1942 to 1988. Extending the time series through 2005, the current limit of the record, yields a linear regression of $4.1 \mathrm{~mm} / \mathrm{yr}$ (fig. 10). Inspection of the water-level trends at Cameron between 1942 and 2005 indicates a rapid rise in relative sea level between 1954 and 1975 but little increase in relative sea level since 1975.

Short-term subsidence rates in the chenier plain east of Calcasieu Lake were monitored near Sweet Lake as part of an investigation of potential environmental impacts associated with a U.S. Department of Energy geopressured-geothermal design well. Van Sickle and Groat (1981) reported a local subsidence rate of $4.2 \mathrm{~mm} / \mathrm{yr}$ based on elevation measurements in the area between 1968 and 1980. Local subsidence rates in the western chenier plain also were investigated in conjunction with construction of the U.S. Department of Energy Strategic Petroleum Reserve at the West Hackberry salt dome. Bauer and Woodrum (2002) reported reductions in local land elevations of more than $60 \mathrm{~cm}$ between 1983 and 2001 at some benchmarks within the West Hackberry site. The induced subsidence, which was related to creep closure of the massive dissolution cavities, was initially rapid, but rates of subsidence declined toward the end of the monitoring period.

Shinkle and Dokka (2004) estimated rates of land subsidence at benchmarks located along Louisiana Highway 27 (LA 27) that were surveyed in 1965 and 1982. Most of the reported rates of subsidence at benchmarks crossing the chenier plain between Hackberry and Holly Beach, including those within SNWR, were between 12 and $15 \mathrm{~mm} / \mathrm{yr}$. The reported rates of subsidence, which are substantially higher 


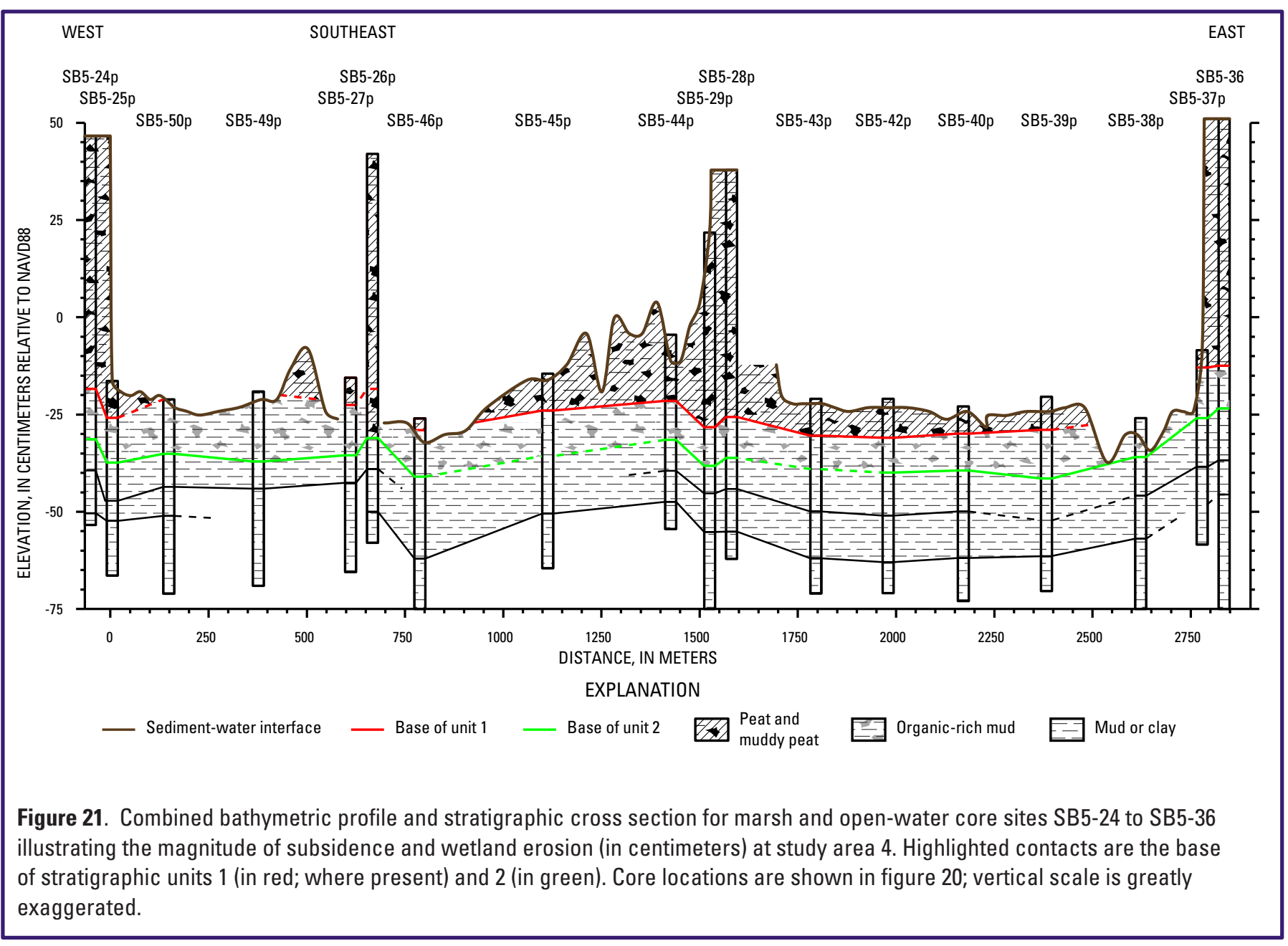

than estimates from other sources, could be an artifact of the methods used by Shinkle and Dokka (2004) or an accurate representation of movement at the benchmark locations between leveling surveys. The benchmark-releveling epoch (1965-1982) partly coincides with the period of highest rates of relative sea-level rise registered at the Cameron tide gage (fig. 10).

The historical subsidence rates in the western chenier plain are substantially lower than most of the historical subsidence rates in the delta plain (Shinkle and Dokka, 2004), but they are similar to the most recent (post-1990) subsidence rates reported for the NOAA tide gage at Grand Isle and the National Geodetic Survey (NGS) Continuously Operating Reference Station (CORS) at Cocodrie (Morton and Bernier, 2010). Subsidence in the Mississippi delta plain was partly explained by compaction and dewatering of the thick underlying Holocene sediments (Roberts and others, 1994). However, those processes are not significant in the chenier plain, where the Holocene section is thin (Gould and McFarlan, 1959). At the core transects, Holocene sediments generally are less than a meter thick (figs. 13, 15, 16, 18, 19, 21, 22, and 24). Although the magnitude of subsidence around the core transects is not great (0 to $38 \mathrm{~cm})$, it likely came from the deep subsurface and not from compaction of the near- surface sediments because near-surface processes, such as storm-water loading and desiccation, can only account for less than $3 \mathrm{~cm}$ of elevation loss (Cahoon, 2006).

\section{Subsurface Fluid Withdrawal}

Areas of wetland loss in the SNWR are located between the Oligocene and lower Miocene producing trends of southwestern Louisiana. At least 107 wells have been drilled within the boundaries of the SNWR, and in 2007 there were four production facilities and 32 producing wells (U.S. Fish and Wildlife Service, 2007). However, the major hydrocarbonproducing fields are on the margins of the refuge, which overlies a deep structural low. The deep syncline formed in response to salt withdrawal and construction of the surrounding salt-cored uplifts and associated structural highs at the Black Bayou, West and East Hackberry, and Cameron Meadows oil-and-gas fields (fig. 2). Of the hydrocarbonproducing fields surrounding the SNWR, only the Mud LakeSecond Bayou complex lacks a shallow salt-piercement core.

Oil-and-gas fields in the chenier plain near the SNWR generally are smaller and have produced less fluid than 

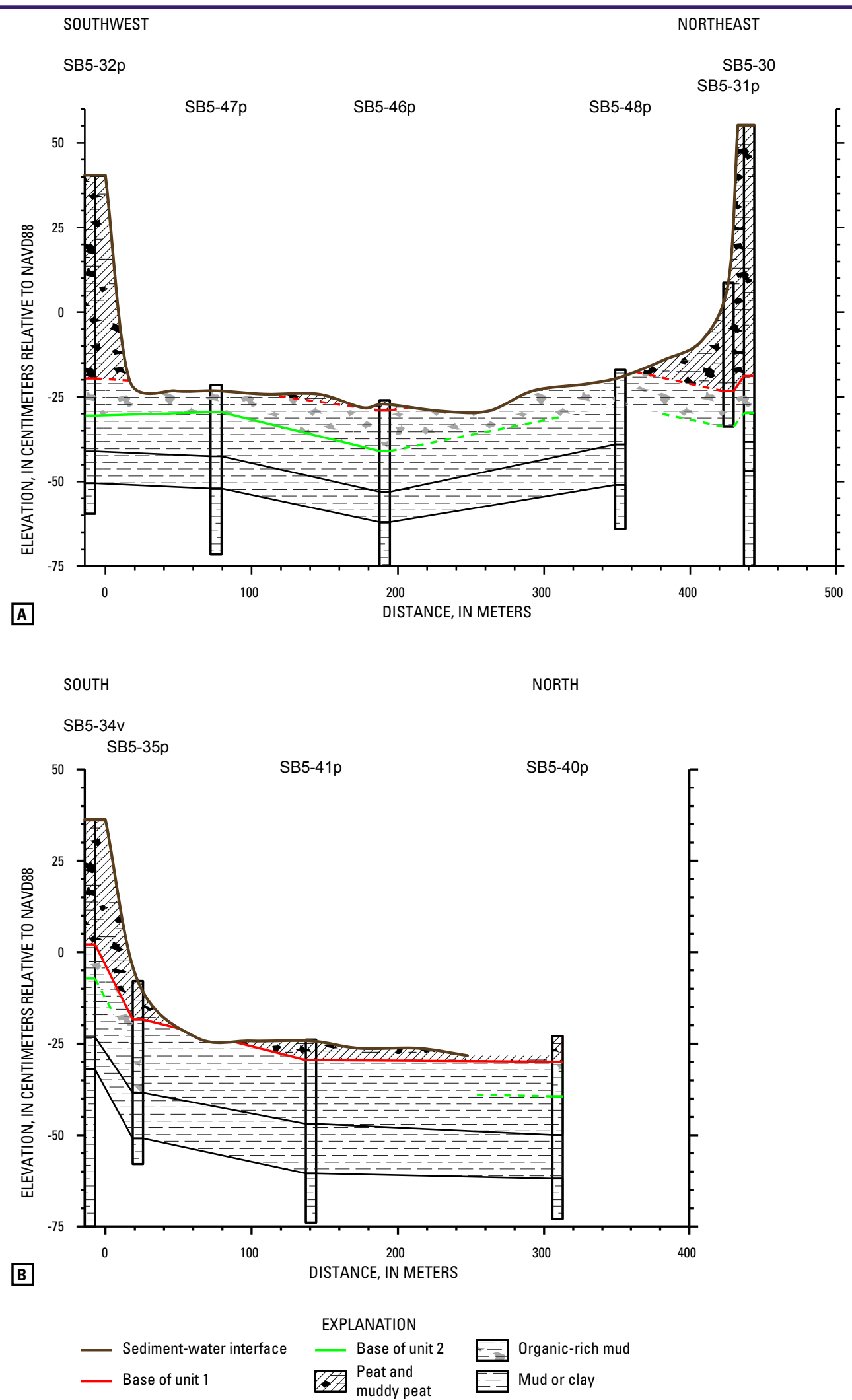

Figure 22. Combined bathymetric profile and stratigraphic cross section for (A) marsh and open-water core sites SB5-32 to SB5-30 and (B) core sites SB5-35 to SB5-40 illustrating the magnitude of subsidence and wetland erosion (in centimeters) at study area 4. Highlighted contacts are the base of stratigraphic units 1 (in red; where present) and 2 (in green). Core locations are shown in figure 20; vertical scale is greatly exaggerated. 


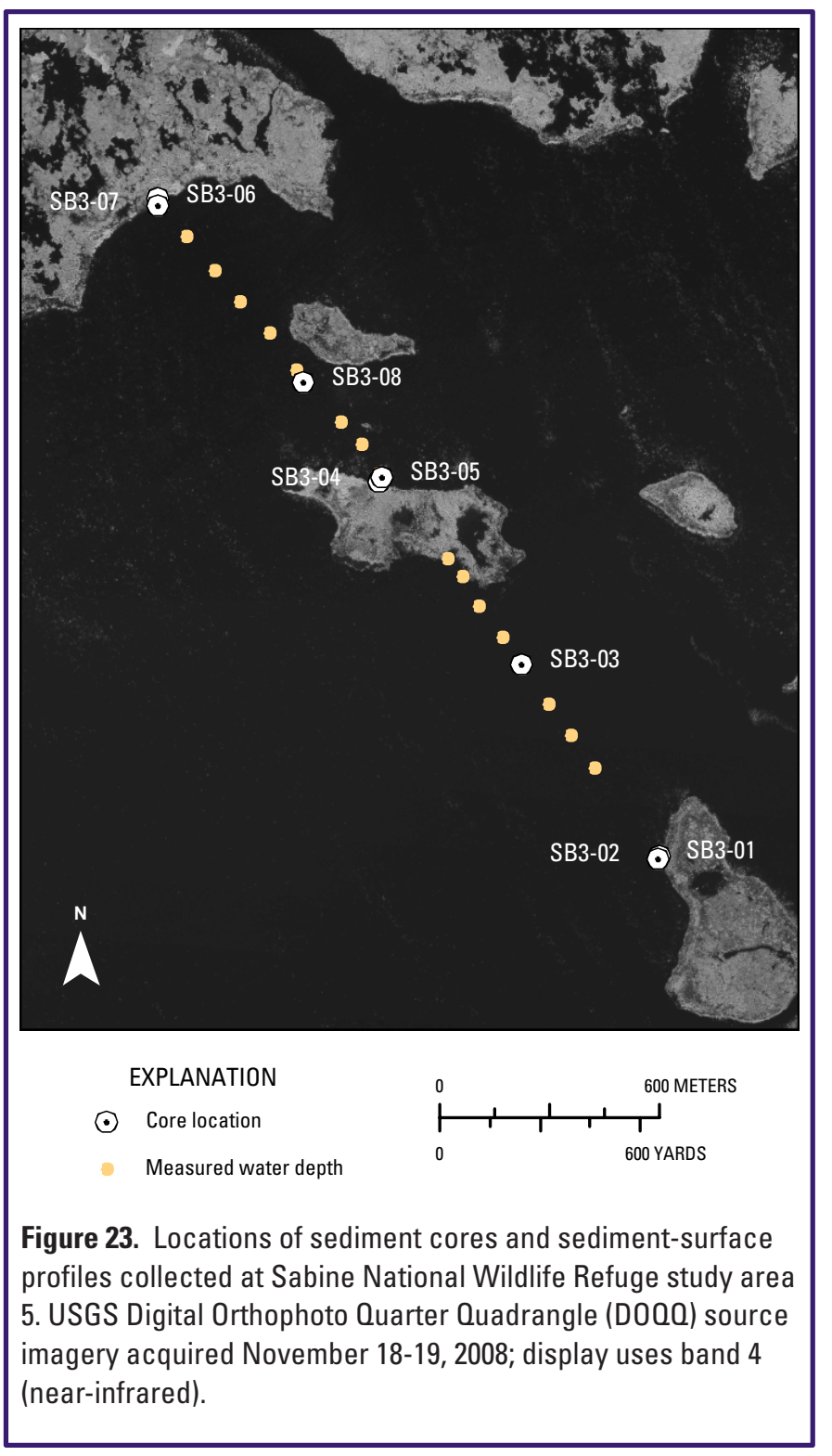

fields in the Mississippi delta plain. An exception is the Hackberry complex, which was discovered in 1902 and has been producing since the 1920s. Together the West and East Hackberry fields have produced more than 231 million barrels (bbls) of oil, 213 billion cubic feet (Bcf) of gas, and 205 million bbls of formation water from more than 1600 wells (table 3). Most of the fluid production was from Oligocene deep-water sandstone reservoirs around the north and west flanks of the structure (Spencer and others, 1994; New Orleans Geological Society, 1962a).

Other historically productive oil-and-gas fields surrounding the wetland-loss areas are Black Bayou, Cameron Meadows, and Mud Lake (table 3). Since their discovery in 1927, the Black Bayou (New Orleans Geological Society, 1962b), Black Bayou South, and Black Bayou Southeast fields have produced more than 60 million bbls of oil, $121 \mathrm{Bcf}$ of gas, and 162 million bbls of formation water from more than 400 wells that penetrated both Miocene and Oligocene sandstone reservoirs. More than 300 wells penetrating Miocene sandstone reservoirs have produced 23 million bbls of oil, $167 \mathrm{Bcf}$ of gas, and 97 million bbls of formation water from the Cameron Meadows and Cameron Meadows East field area, which was discovered in 1929 (New Orleans Geological Society, 1962c). The Mud Lake, Mud Lake East, and Second Bayou fields (Hoffman, 1970; Sloane, 1971) encompass primarily a gas-producing area that yielded 17 million bbls of oil, 1.1 trillion cubic feet of gas, and 41 million bbls of formation water from lower Miocene sandstone reservoirs penetrated by more than 200 wells.

The history of fluid withdrawal is slightly different for each of the oil-and-gas fields, but the general trend shows relatively low production rates from the time of discovery until the early 1960s, accelerated hydrocarbon production beginning in the 1960s and peaking about 1970 , then rapidly declining production to rates below those of the pre-acceleration phase (fig. 25). For these same fields, water production was erratic and typically peaked after hydrocarbon production peaked, but high rates of water production were sustained through the 1990s.

Approximately 30 shallow groundwater wells have been drilled within the SNWR. Most of the water wells were used for rig water in support of hydrocarbon exploration (Louisiana Department of Transportation and Development, 2010) and they are no longer producing groundwater. The total volume of water extracted from these wells was probably minor and local in its impact.

\section{Discussion and Conclusions}

Comparing wetland and wetland-loss parameters at SNWR Management Units 1, 3, and 5 (table 4) shows that the range of emergent-marsh elevations was similar except for the anomalously high interior-marsh elevation at core site SB1-13 in Unit $1(71 \mathrm{~cm})$. The magnitudes of subsidence were similar at all study areas, but peat thicknesses and the depths of erosion were generally greater in Units 3 and 5, so the accommodation space formed was also greater in those units. At most core sites in SNWR, magnitudes of subsidence were substantially less than those of erosion. The early wet-marsh stage of wetland loss at SNWR, which is evident on the 1960s and 1978 imagery, is a clear indicator that minor but rapid subsidence was the process that initiated fragmentation and conversion of the broad continuous marsh meadows to open water. However, erosion eventually exceeded subsidence in forming the accommodation space and excavating the former emergent-marsh surface to extant water depths. Vegetation in the emergent marsh and marsh remnants in SNWR Units 1 and 5 is healthy and not adversely affected by prevailing salinities of the surrounding water bodies. The repeated surveys by Chabreck and others (1968; 2001), Sasser and others (2008), and Steyer and others (2010) show that marsh-vegetation 


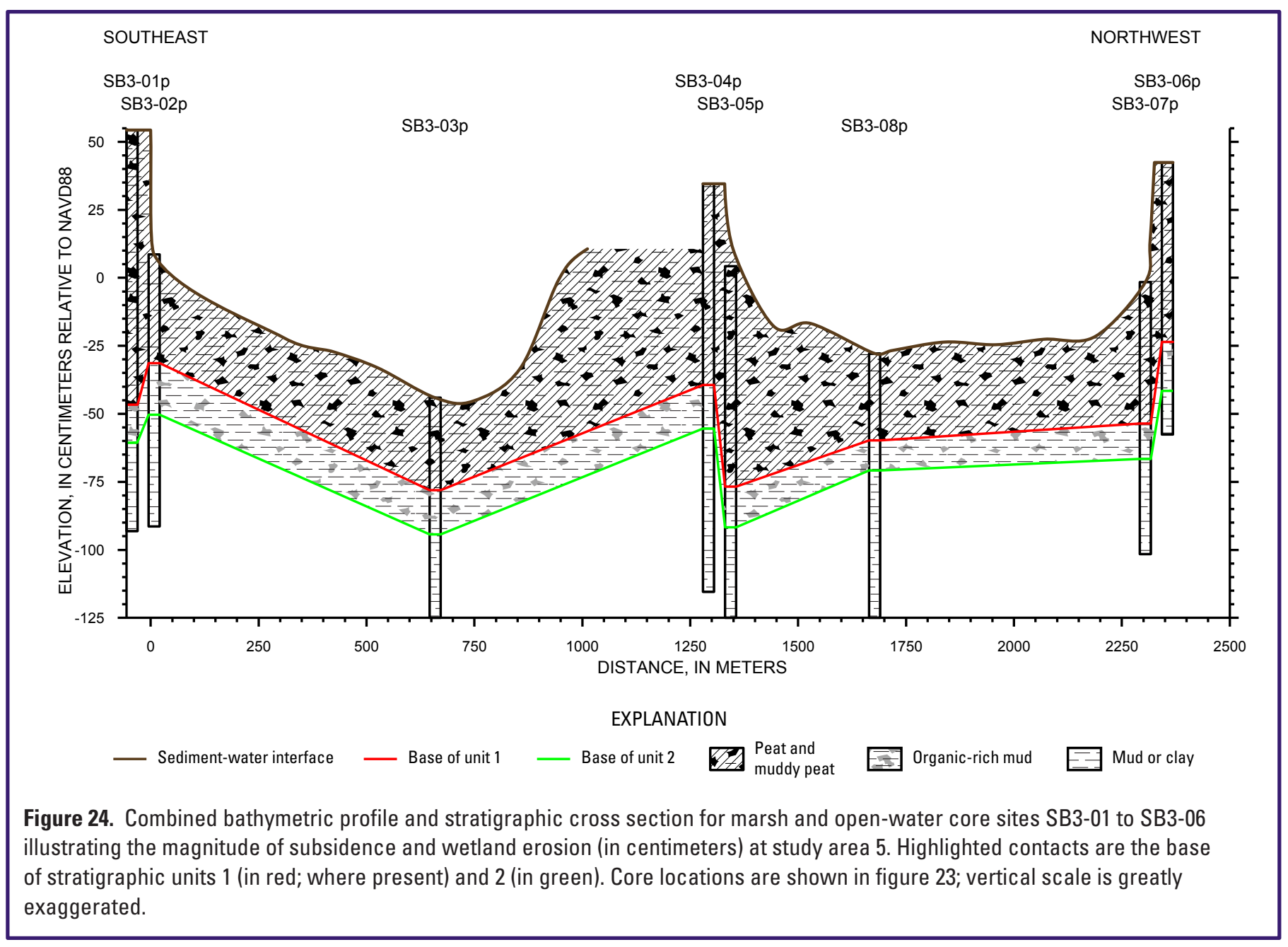

communities in the western chenier plain are adaptable to environmental stresses such as changing soil salinities and seasonal or episodic flooding events. Thus, increased salinities in some marshes associated with enlarging the deep-draft navigation channels that transverse Sabine and Calcasieu Lakes have contributed to changes in dominant vegetation type rather than causing widespread wetland loss.

The wetland and wetland-loss parameters at SNWR provide a basis for comparing attributes of land-water change in the western chenier plain with the same attributes in the delta plain (table 4) that were reported by Morton and others $(2005 ; 2009 a)$. Compared to the delta-plain cores, average emergent-marsh elevations were generally higher in the western chenier plain, where historical subsidence rates were lower. The organic-rich marsh sediments are generally thinner in the SNWR cores, probably as a result of lower natural subsidence rates and different sediment budget and hydrodynamic regimes that existed in the western chenier plain when the marshes were healthy and aggrading. In general, in SNWR, the peat facies was substantially thinner, the water depths were shallower, and magnitudes of subsidence and total accommodation were less than in the delta plain. In the delta plain, peat deposits were preserved at all the open-water core sites because subsidence generally exceeded erosion and the thickness of the peat deposits was so great that they were preserved even where erosion was greater than subsidence. However, at SNWR, peat deposits are absent at most open-water sites because erosion generally exceeded subsidence and the peat deposits generally were thin.

Analysis of disparate data from four independent sources shows that the highest rates of wetland loss, land subsidence, and subsurface fluid production in the western chenier plain all occurred between the mid-1950s and the early 1980s. Annual data showing continuous trends were available only for the relative rise in sea level at the Cameron tide gage and for production of oil, gas, and formation water at fields surrounding SNWR (figs. 10 and 23). Data for the other two parameters, wetland loss and local subsidence rates at benchmarks, were for discrete periods. Furthermore, for local subsidence rates, there was no information regarding rates before and after the leveling epochs that could be used to establish a trend. However, the geodetic land-subsidence rates were higher than indicated by other independent methods, such as the tide-gage records.

The temporal and spatial coincidence of rapid wetland loss, highest rates of land-surface subsidence, and high rates of 
Table 3. Discovery year, number of wells drilled, and cumulative volumes of fluids produced through 2009 from oil-and-gas field complexes surrounding the Sabine National Wildlife Refuge wetlands.

[Data from Louisiana Department of Natural Resources and PI/Dwights PLUS database (IHS, Inc., 2009). Field locations are shown in figure 2. Abbreviations: bbls, barrels; mcf, million cubic feet.]

\begin{tabular}{lccccc}
\multicolumn{1}{c}{ Field Names } & $\begin{array}{c}\text { Discovery } \\
\text { Year }\end{array}$ & Wells & $\begin{array}{c}\text { Cummulative Oil } \\
\text { (bbls) }\end{array}$ & $\begin{array}{c}\text { Cummulative Gas } \\
\text { (mcf) }\end{array}$ & $\begin{array}{c}\text { Cummulative Water } \\
\text { (bbls) }\end{array}$ \\
\hline $\begin{array}{l}\text { East and West Hackberry } \\
\text { Black Bayou, Black Bayou South, and } \\
\quad \text { Black Bayou Southeast }\end{array}$ & 1902 & 1651 & $231,686,078$ & $213,875,169$ & $205,561,797$ \\
$\begin{array}{l}\text { Cameron Meadows and Cameron } \\
\quad \text { Meadows East }\end{array}$ & 1927 & 455 & $60,866,643$ & $121,830,267$ & $162,064,978$ \\
$\begin{array}{l}\text { Mud Lake, Mud Lake East, and Second } \\
\text { Bayou }\end{array}$ & 1929 & 316 & $23,394,287$ & $167,330,703$ \\
\hline
\end{tabular}

oil-and-gas production in the western chenier plain is similar to those same trends in the delta plain, where long-term, largevolume subsurface fluid production was largely responsible for the land-surface subsidence that initiated widespread wetland loss (Morton and others, 2005; 2009a). Initial subsidence lowered the SNWR emergent marshes to a position where they were more susceptible to erosion by storm waves. Another major contributor to localized historical wetland loss in the western chenier plain was the impact of extreme hurricanes, such as those of Audrey in 1957 and Rita in 2008.

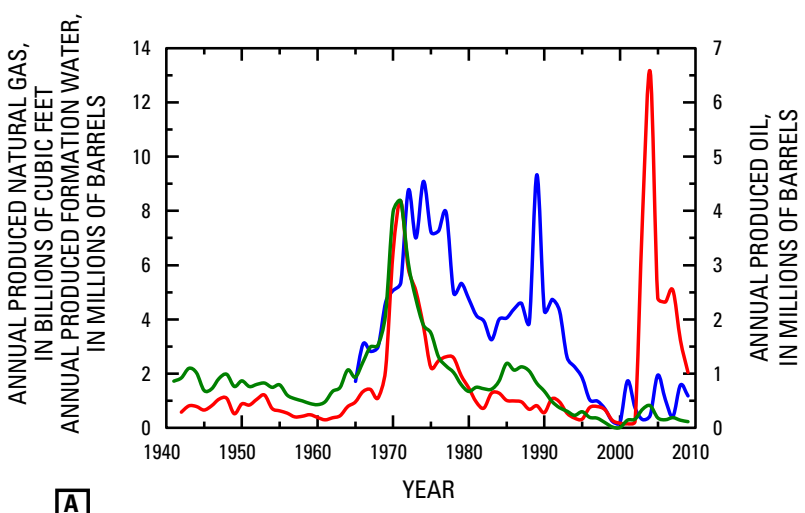

A

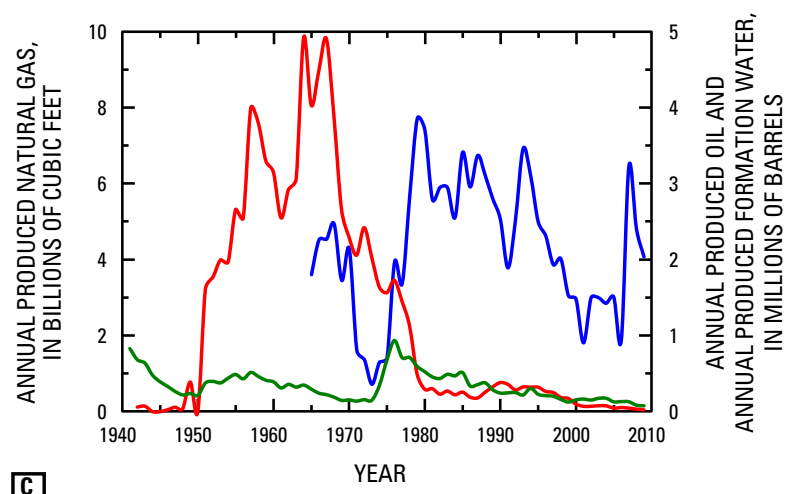

EXPLANATION
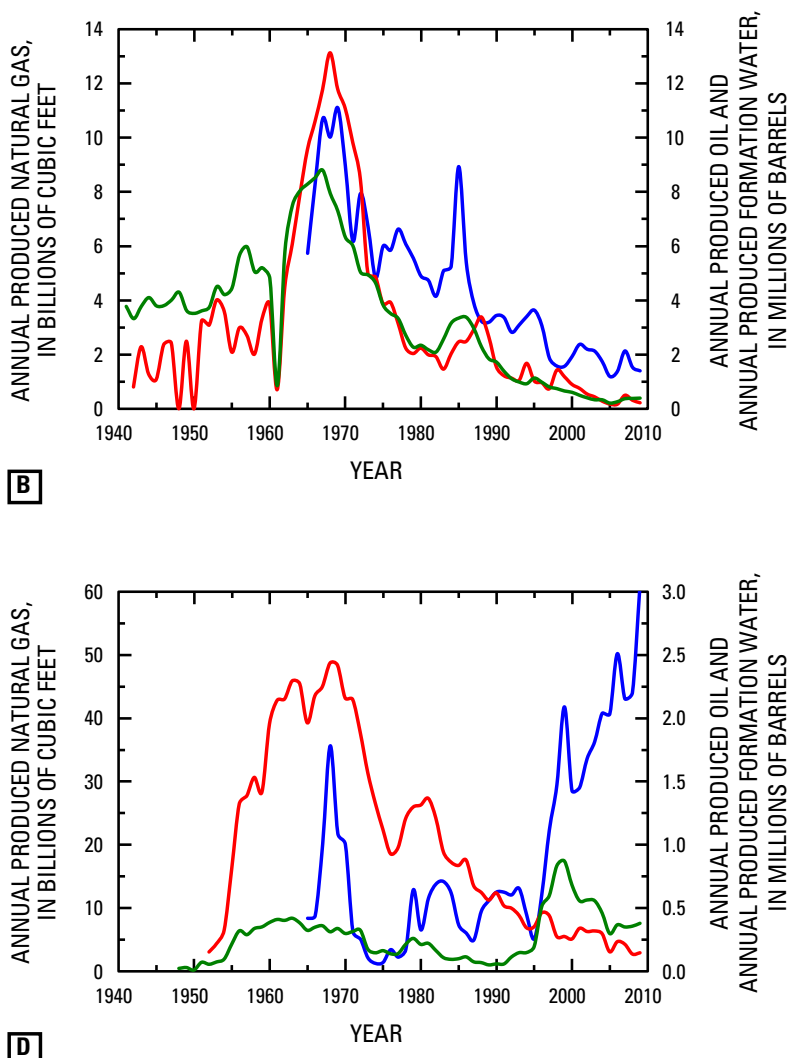

- Oil - Gas W Water

Figure 25. Annual fluid production through 2009 from oil-and-gas fields surrounding the Sabine National Wildlife Refuge. (A) Black Bayou complex, (B) East and West Hackberry complex, (C) Cameron Meadows complex, and (D) Mud Lake and Second Bayou complex. Field locations are shown in figure 2. Data from Louisiana Department of Natural Resources and PI/Dwights PLUS database (HIS, Inc., 2009). 


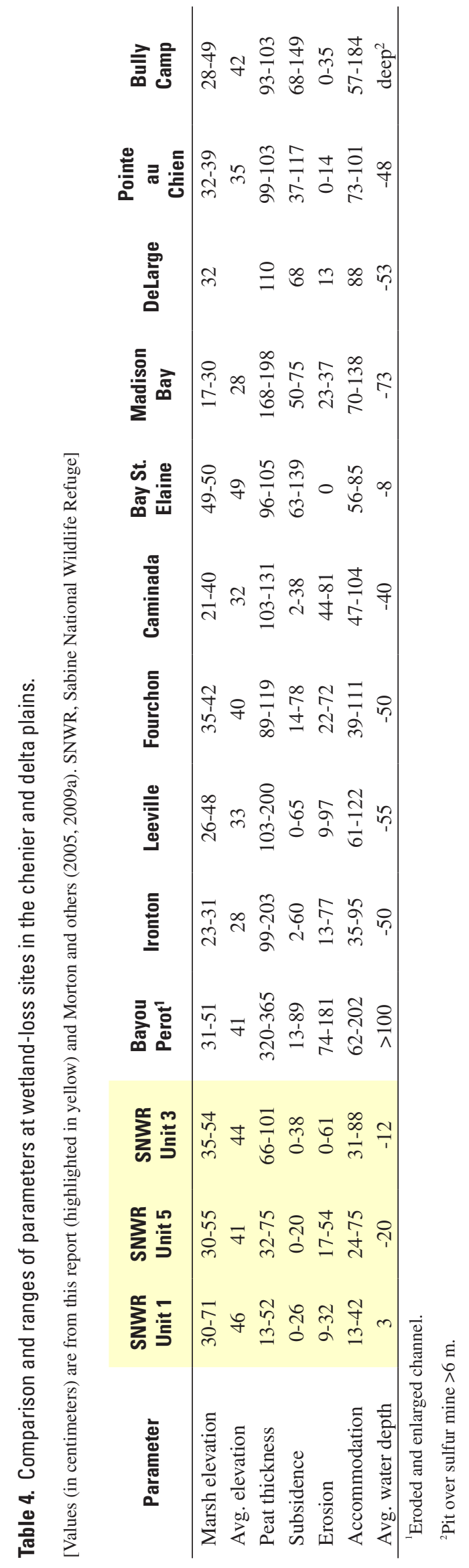




\section{Acknowledgments}

We thank Gary Hill and Gregg Snedden for operating the airboats and assisting with field operations, and the staff at Sabine National Wildlife Refuge for allowing access to the coring sites. We also thank John Barras for providing some of the historical images and Jennifer Miselis and Greg Steyer for conducting scientific and editorial reviews that improved the report.

\section{References}

Barras, J.A., 2006, Land area changes in coastal Louisiana after the 2005 hurricanes - A series of three maps: U.S. Geological Survey Open-File Report 2006-1274. (Also available at http://pubs.usgs.gov/of/2006/1274/.)

Barras, J.A., Bernier, J.C., and Morton, R.A., 2008, Land area change in coastal Louisiana - A multidecadal perspective (from 1956 to 2006): U.S. Geological Survey Scientific Investigations Map 3019, scale 1:250,000, 14 p. pamphlet. (Also available at http://pubs.usgs.gov/sim/3019/.)

Bauer, S.J., and Woodrum, Stacy, 2002, Analysis of subsidence data from West Hackberry, Louisiana: Sandia National Laboratories, Albuquerque, SAND2002-1643, 36 p. (Also available at http://prod.sandia.gov/techlib/access-control. cgi/2002/021643.pdf.)

Bernier, J.C., Morton, R.A., and Barras, J.A., 2006, Constraining rates and trends of historical wetland loss, Mississippi River delta plain, south-central Louisiana, in Xu, Y.J. and Singh, V.P., eds., Coastal Environment and Water Quality - Proceedings of the AIH 25th Anniversary Meeting and International Conference "Challenges in Coastal Hydrology and Water Quality": Highlands Ranch, CO, Water Resources Publications, LLC, p. 371-383.

Boumans, R.M., and Day, J.W. Jr., 1994, Effects of two Louisiana marsh management plans on water and materials flux and short-term sedimentation: Wetlands, v. 14, p. 247-261.

Britsch, L.D., and Dunbar, J.B., 1996, Land loss in coastal Louisiana, Cameron, LA: U.S. Army Corps of Engineers Technical Report GL-90-2, Map 1 of 7, scale 1:125,000.

Cahoon, D.R., 1994, Recent accretion in two managed marsh impoundments in coastal Louisiana: Ecological Applications, v. 4, p. 166-176.

Cahoon, D.R., 2006. A review of major storm impacts on coastal wetland elevations: Estuaries and Coasts, v. 29, p. 889-898.

Chabreck, R.H., Joanen, J.T., and Palmisano, A.W., 1968, Vegetative type map of the Louisiana coastal marshes: Loui- siana Wildlife and Fisheries Commission, New Orleans, Louisiana.

Chabreck, R.H., Linscombe, G., Hartley, S., Johnston, J.B., Martucci, A., 2001, Coastal Louisiana marsh-vegetation types: U.S. Geological Survey National Wetlands Research Center, CD-ROM.

Clark, D., and Mazourek, J., 2004, Final Environmental Assessment East Sabine Lake Hydrologic Restoration Project Construction Unit 1 (CS-32) Cameron Parish, Louisiana: U.S. Fish and Wildlife Service, Ecological Services, 32 p., plus app. (Also available at http://lacoast.gov/reports/env/ East\%20Sabine\%20Lake\%20CS-32.pdf.)

Cowan, J.H., Jr., Turner, R.E., and Cahoon, D.R., 1988, Marsh management plans in practice: Do they work in coastal Louisiana, USA?: Environmental Management, v. 12, p. 37-53.

Davis, D.W., 1976, Trainasse: Annals of the Association of American Geographers, v. 66, p. 349-359.

Day, J.W., Jr., Britsch, L.D., Hawes, S.R., Shaffer, G.P., and Cahoon, D.J., 2000, Pattern and process of land loss in the Mississippi Delta: A spatial and temporal analysis of wetland habitat change: Estuaries and Coasts, v.23, p. 425-438.

Day, R.H., Holz, R.K., and Day, J.W., 1990, An inventory of wetland impoundments in the coastal zone of Louisiana, USA - Historical trends: Environmental Management, v. 14, p. 229-240.

Douglas, B.C., 2001, Sea level change in the era of the recording tide gauge, in Douglas, B.C., Kearney, M.S., and Leatherman, S.P., eds., Sea level rise: New York, Academic Press, p. 37-62.

Federal Geographic Data Committee [prepared for the Federal Geographic Data Committee by the U.S. Geological Survey], 2006, FGDC Digital Cartographic Standard for Geologic Map Symbolization: Reston, Va., Federal Geographic Data Committee Document Number FGDC-STD-013-2006, 290 p., 2 plates. (Also available at http://ngmdb.usgs.gov/ $\left.f g d c \_g d s /.\right)$

Flynn, K.M., Mendelssohn, I.A., and Wilsey, B.J., 1999, The effect of water level management on the soils and vegetation of two coastal Louisiana marshes: Wetlands Ecology and Management, v. 7, p. 193-218.

Frazier, D.E., 1967, Recent deltaic deposits of the Mississippi River: Their development and chronology: Transactions, Gulf Coast Association of Geological Societies, v. 17, p. 287-315.

Goddard, E.N., Trask, P.D., De Ford, R.K., Rove, O.N., Singewald, J.T., Jr., and Overbeck, R.M.,

1963, Rock-color chart: Geological Society of America, New 
York, NY, 16 p.

Gould, H.R., and McFarlan, E., Jr., 1959, Geologic history of the chenier plain southwestern Louisiana: Transactions, Gulf Coast Association of Geological Societies, v. 9, p. 261-270.

Heinrich, P.V., 2005a, Port Arthur 30 x 60 minute geologic quadrangle: Louisiana Geological Survey, Baton Rouge, LA, scale 1:100,000.

Heinrich, P.V., 2005b, Distribution and origin of fault-line scarps of southwest Louisiana, USA: Transactions, Gulf Coast Association of Geological Societies, v. 55, p. 284293.

Heinrich, P.V., Snead, J.I., and McCulloh, R.P., 2002, The Lake Charles 30 X 60 minute geologic quadrangle: Louisiana Geological Survey, Baton Rouge, LA, scale 1:100,000.

Hoffmann, E.A., Jr., 1970, Mud Lake and Second Bayou Fields, Cameron Parish, Louisiana, in Burns, K.G., ed., Typical oil and gas fields of southwestern Louisiana: Lafayette Geological Society, v. II, p. 20-20f.

Holdahl, S.R., and Morrison, N.L., 1974, Regional investigations of vertical crustal movements in the U.S. using precise relevelings and mareograph data: Tectonophysics, v. 23, p. 373-390.

IHS Inc., 2009, PI/Dwights PLUS on CD, version 1.7: available from IHS Inc., 15 Inverness Way East, Englewood, CO 80112 (http://energy.ihs.com/Products/Usdata/index.htm).

Intergovernmental Panel on Climate Change, 2007, Climate Change 2007: Impacts, adaptation and vulnerability, in Parry, M.L., Canziani, O.F., Palutikof, J.P., van der Linden, P.J., and Hanson, C.E., eds., Contribution of Working Group II to the Fourth Assessment Report of the Intergovernmental Panel on Climate Change: Cambridge, U.K., Cambridge University Press, 976 p.

Jowsey, P.C., 1966, An improved peat sampler: New Phytologist, v. 65, p. 245-248.

Kolb, C.R., and Van Lopik, J.R., 1958, Geology of the Mississippi River deltaic plain, southeastern Louisiana: U.S. Army Corps of Engineers Waterways Experiment Station Technical Report 3-383, Vicksburg, MS.

Kuhn, N.L., Mendelssohn, I.A., and Reed, D.J., 1999, Altered hydrology effects on Louisiana salt marsh function: Wetlands, v. 19, p. 617-626.

Lanesky, D.E., Logan, B.W., Brown, R.G., and Hine, A.C., 1979, A new approach to portable vibracoring underwater and on land: Journal of Sedimentary Petrology, v. 49, p. 654-657.

Louisiana Coastal Wetlands Conservation and Restoration
Task Force, 2002, Hydrologic Investigation of the Louisiana Chenier Plain: Baton Rouge, LA, Louisiana Department of Natural Resources, Coastal Restoration Division, 135 p., plus app. (Also available at http://www.lacoast.gov/reports/ static/HILCP_1.pdf.)

Louisiana Department of Transportation and Development, 2010, LA DOTD Water Well Registry: Louisiana Department of Transportation database, accessed July 20, 2010 at http://gis.dotd.la.gov/WellsByParish/.

McBride, R.A., Taylor, M.J., and Byrnes, M.R., 2007, Coastal morphodynamics and chenier-plain evolution in southwestern Louisiana, USA - A geomorphic model: Geomorphology, v. 88, p. 367-422.

Miller, M., 2003, Monitoring Plan for Replace Sabine Refuge Water Control Structures at Headquarters Canal, West Cove Canal, and Hog Island Gully: Louisiana Department of Natural Resources, Coastal Restoration Division, 13p. (Also available at http://www.lacoast.gov/reports/mp/CS23.pdf.)

Morton, R.A., and Barras, J.A., in press, Hurricane impacts on coastal wetlands: A half-century record of storm-generated features from southern Louisiana: Journal of Coastal Research.

Morton, R.A., and Bernier, J.C., 2010, Recent subsidence-rate reductions in the Mississippi Delta and their geological implications: Journal of Coastal Research, v. 26, p. 555-561.

Morton, R.A., Bernier, J.C., and Barras, J.A., 2006, Evidence of regional subsidence and associated interior wetland loss induced by hydrocarbon production, Gulf Coast region, USA: Environmental Geology, v. 50, p. 261-274.

Morton, R.A., Bernier, J.C., Barras, J.A., and Ferina, N.F., 2005, Rapid subsidence and historical wetland loss in the Mississippi delta plain: Likely causes and future implications: U.S. Geological Survey Open-file Report 2005-1216, 116 p. (Also available at http://pubs.usgs.gov/ of/2005/1216/.)

Morton, R.A., Bernier, J.C., and Buster, N.A., 2009b, Simple methods for evaluating accommodation space formation in coastal wetlands: Wetlands, v. 29., no. 3, p. 997-1003.

Morton, R.A., Bernier, J.C., and Kelso, K.W., 2009a, Recent subsidence and erosion at diverse wetland sites in the southeastern Mississippi delta plain: U.S. Geological Survey Open-File Report 2009-1158, 39 p., plus app. (p. 41-221). (Also available at http://pubs.usgs.gov/of/2009/1158/.)

Morton, R.A., Bernier, J.C., Kelso, K.W., and Barras, J.A., 2010, Quantifying large-scale historical formation of accommodation space in the Mississippi Delta: Earth Surface Processes and Landforms, v. 35, p. 1625-1641.

Morton, R.A., Tiling, G., and Ferina, N.F., 2003, Causes of hotspot wetland loss in the Mississippi delta plain: Environ- 
mental Geosciences, v. 10. p. 71-80.

Morton, R.A., and White, W.A., 1997, Characteristics of and corrections for core shortening in unconsolidated sediments: Journal of Coastal Research, v. 13, p. 761-769.

National Oceanic and Atmospheric Administration (NOAA), 2010, Sabine Pass, TX: National Oceanic and Atmospheric Administration Tides and Currents database, accessed July 1, 2010, at http://tidesandcurrents.noaa.gov/sltrends/ sltrends_station.shtml?stnid $=8770570 \% 20$ Sabine $\% 20$ Pass\%20North,\%20TX.

National Research Council, 2006, Drawing Louisiana's new map: The National Academies Press, Washington, D.C., 190 p.

New Orleans Geological Society, 1962a, Hackberry Field, Cameron Parish, in Salt domes of South Louisiana, v. 2, p. 20-23.

New Orleans Geological Society, 1962b, Black Bayou Field, Cameron Parish, in Salt domes of South Louisiana, v. 2, p. 12-13.

New Orleans Geological Society, 1962c, Cameron Meadows Field, Cameron Parish, in Salt domes of South Louisiana, v. 2, p. 16-17.

Penland, S., and Ramsey, K.E., 1990, Relative sea-level rise in Louisiana and the Gulf of Mexico - 1908-1988: Journal of Coastal Research, v. 6, p. 323-342.

Penland, S., and Suter, J.R., 1989, The geomorphology of the Mississippi River chenier plain: Marine Geology, v. 90, p. 231-258.

Reed, D.J., 1992, Effect of weirs on sediment deposition in Louisiana coastal marshes: Environmental Management, v. 16 , p. $55-65$.

Reed, D.J., De Luca, N., and Foote, A.L., 1997, Effect of hydrologic management on marsh surface sediment deposition in coastal Louisiana: Estuaries, v. 20, p. 301-311.

Roberts, H.H., 1997, Dynamic changes of the Holocene Mississippi River delta plain - The delta cycle: Journal of Coastal Research, v. 13. p. 605-627.

Roberts, H.H., Bailey, A., and Kuecher, G.J., 1994, Subsidence in the Mississippi River Delta - Important influences of valley filling by cyclic deposition, primary consolidation phenomena, and early diagenesis: Transactions, Gulf Coast
Association of Geological Societies, v. 44, p. 619-629.

Sasser, C.E., Visser, J.M., Mouton, Edmond, Linscombe, Jeb, and Hartley, S.B., 2008, Vegetation types in coastal Louisiana in 2007: U.S. Geological Survey Open-File Report 2008-1224, 1 sheet, scale 1:550,000. (Also available at http://pubs.usgs.gov/of/2008/1224/.)

Sharp, L.A., 2003, Monitoring Plan for Sabine National Wildlife Refuge Erosion Protection: Louisiana Department of Natural Resources, Coastal Restoration Division, 8 p. (Also available at http://www.lacoast.gov/reports/mp/CS18rev. $p d f$.

Shinkle, K.D., and Dokka, R.K., 2004, Rates of vertical displacement at benchmarks in the Lower Mississippi Valley and the Northern Gulf Coast: National Oceanic and Atmospheric Administration Technical Report 50, 135 p.

Sloane, B.J., 1971, Recent developments in the Miocene Planulina gas trend of south Louisiana: Transactions, Gulf Coast Association of Geological Societies, v. 21, p. 200-210.

Spencer, J.A., Sharpe, C.L., Gillham, T.H., and Wright, D.N., 1994, Depositional patterns and structural styles - Hackberry salt dome, Cameron Parish, Louisiana: Transactions, Gulf Coast Association of Geological Societies, v. 44, p. 701-708.

Steyer, G.D., Cretini, K.F., Piazza, Sarai., Sharp, L.A., Snedden, G.A., and Sapkota, Sijan, 2010, Hurricane influences on vegetation community change in coastal Louisiana: U.S. Geological Survey Open-File Report 2010-1105, 21 p. (Also available at http://pubs.usgs.gov/of/2010/1105/)

Steyer, G.D., Sasser, C.E., Visser, J.M., Swenson, E.M., Nyman, J.A., and Raynie, R.C., 2003, A proposed coastwide reference monitoring system for evaluating wetland restoration trajectories in Louisiana: Environmental Monitoring and Assessment, no. 81, p. 107-117.

U.S. Fish and Wildlife Service, 2007, Comprehensive conservation plan, Sabine National Wildlife Refuge, Cameron Parish, Louisiana: U.S. Fish and Wildlife Service, Atlanta, GA, 235 p.

Van Sickle, V.R., and Groat, C.G., 1981, Subsidence and induced faulting: Key environmental issues in geopressuredgeothermal resource development: Proceedings, Fifth Conference, Geopressured-Geothermal Energy, U.S. Gulf Coast, Baton Rouge, LA, p. 325-330. 